\title{
12. SITE 656: DE MARCHI SEAMOUNT ${ }^{1}$
}

\author{
Shipboard Scientific Party²
}

\section{HOLE 656A}

Date occupied: 13 February 1986

Date departed: 15 February 1986

Time on hole: 1 day, $22 \mathrm{hr}$

Position: $40^{\circ} 11.062^{\prime} \mathrm{N}, 12^{\circ} 11.030^{\prime} \mathrm{E}$

Water depth (sea level, corrected m, echo-sounding): 3597

Water depth (rig floor, corrected m, echo-sounding): 3608

Bottom felt (m, drill pipe length from rig floor): 3606

Total depth (m): 3842.4

Penetration (m): 236.4

Number of cores: 14

Total length of cored section (m): 133.6

Total core recovered $(\mathrm{m}): 58.7$

Core recovery $(\%): 43.9$

Deepest sedimentary unit cored:

Depth sub-bottom (m): 179.1

Nature: gravel and pebble-bearing calcareous-dolomitic mud

Age: probably Messinian

Measured vertical sound velocity $(\mathrm{km} / \mathrm{s}): 1.6$

Igneous or metamorphic basement: undetermined

${ }^{1}$ Kastens, K. A., Mascle, J, Auroux, C., et al., 1987. Proc., Init. Repts. (Pt. A), $O D P, 107$.

${ }^{2}$ Kim A. Kastens (Co-Chief Scientist), Lamont-Doherty Geological Observatory, Palisades, NY 10964; Jean Mascle (Co-Chief Scientist), Laboratoire de Géodynamique Sous-Marine, Université Pierre et Marie Curie, BP 48, 06230 Villefranche-sur-Mer, France; Christian Auroux, Staff Scientist, Ocean Drilling Program, Texas A\&M University, College Station, TX 77843; Enrico Bonatti, Lamont-Doherty Geological Observatory, Palisades, NY 10964; Cristina Broglia, Lamont-Doherty Geological Observatory, Palisades, NY 10964; James Channell, Department of Geology, 1112 Turlington Hall, University of Florida, Gainesville, FL 32611; Pietro Curzi, Istituto di Geologia Marina, Via Zamboni, 65, 40127 Bologna, Italy; Kay-Christian Emeis, Ocean Drilling Program, Texas A\&M University, College Station, TX 77843; Georgette Glaçon, Laboratoire de Stratigraphie et de Paleoécologie, Centre Saint-Charles, Université de Provence, 3, Place Victor Hugo, 13331 Marseille Cedex, France; Shiro Hasegawa, Institute of Geology, Faculty of Science, Tohoku University, Aobayama, Sendai, 980, Japan; Werner Hieke, Lehrstuhl für Allgemeine, Angewandte und Ingenieur-Geologie, Abt. Sedimentforschung und Meeresgeologie, Technische Universität München, Lichtenbergstrasse 4, D-8046 Garching, Federal Republic of Germany; Floyd McCoy, Lamont-Doherty Geological Observatory, Palisades, NY 10964; Judith McKenzie, Department of Geology, University of Florida, 1112 Turlington Hall, Gainesville, FL 32611; Georges Mascle, Institut Dolomieu, Université Scientifique et Médicale de Grenoble, 15 Rue Maurice Gignoux, 38031 Grenoble Cedex, France; James Mendelson, Earth Resources Laboratory E34-366, Department of Earth, Atmospheric and Planetary Sciences, Massachusetts Institute of Technology, 42 Carleton Street, Cambridge, MA 02142; Carla Müller, Geol. Paläont. Institut, Universität Frankfurt/Main, 32-34 Senckenberg-Anlage, D-6000 Frankfurt/Main 1, Federal Republic of Germany (current address: 1 Rue Martignon, 92500 RueilMalmaison, France); Jean-Pierre Réhault, Laboratoire de Géodynamique SousMarine, Université Pierre et Marie Curie, BP 48, 06230 Villefranche-sur-Mer, France; Alastair Robertson, U.S. Geological Survey, 345 Middlefield Road, Menlo Park, CA 94025 (current address: Department of Geology, Grant Institute, University of Edinburgh, Edinburgh, EH9 3JW, United Kingdom); Renzo Sartori, Istituto di Geologia Marina, Via Zamboni, 65, 40127 Bologna, Italy; Rodolfo Sprovieri, Istituto di Geologia, Corso Tukory, 131, Palermo, Italy; Masayuki Torii, Department of Geology and Mineralogy, Faculty of Science, Kyoto University, Kyoto, 606, Japan.

\section{HOLE 656B}

Date occupied: 15 February 1986

Date departed: 16 February 1986

Time on hole: 1 day, $5 \mathrm{hr}$

Position: $40^{\circ} 11.09^{\prime} \mathrm{N}, 12^{\circ} 11.45^{\prime} \mathrm{E}$

Water depth (sea level, corrected m, echo-sounding): 3597

Water depth (rig floor, corrected m, echo-sounding): 3608

Bottom felt ( $m$, drill pipe length from rig floor): 3606

Total depth (m): 3727.8

Penetration (m): 121.8

Number of cores: 7

Total length of cored section (m): 66.3

Total core recovered $(\mathrm{m}): 56.39$

Core recovery $(\%): 85$

Deepest sedimentary unit cored:

Depth sub-bottom (m): 106

Nature: gravels and pebble-bearing calcareous-dolomitic mud

Age: probably Messinian

Measured vertical sound velocity $(\mathrm{km} / \mathrm{s}): 1.6$

Igneous or metamorphic basement: undetermined

Principal results: Operations: Site 656 was located on the westward flank of de Marchi Seamount, which is the easternmost continental fault-bounded tilted block on the lower Sardinian margin (Fig. 1). Two holes were rotary drilled (Fig. 2). Hole 656A was located downdip from the apparent pinch-out of a thin wedge of inferred syn-rift sediments. The upper $102 \mathrm{~m}$ of Pleistocene turbidites was not cored. Hole $656 \mathrm{~A}$ was abandoned prematurely when the pipe stuck in synrift sand and gravel. The ship was offset to drill Hole 656B just updip of the apparent pinch-out of the syn-rift wedge. The upper $55 \mathrm{~m}$ of Pleistocene turbidites was not cored. Hole 656B was terminated to leave for Marseille. Neither hole was logged, and no heat flow measurements were made.

Four sedimentary units were recovered:

Unit I: Cores 107-656A-1R to 107-656A-4R-1, $5 \mathrm{~cm}$, and 107 656B-1R to 107-656B-3R; depth: 656A: 102.8-131.3 mbsf; 656B: 55.5-83.9 mbsf; age: late Pleistocene.

Unit I contains detrital and volcanogenic sediments, mostly finegrained, with a subordinate fraction of biogenic carbonates. The detrital component includes zircon, pyroxene, and blue amphibole; the latter suggests a high-pressure/low-temperature metamorphic source terrain.

Unit II: Cores 107-656A-4R-1, $5 \mathrm{~cm}$, to $107-656 \mathrm{~A}-7 \mathrm{R}, \mathrm{CC}$, and 107-656B-4R; depth: 656A: 131.3-169.7 mbsf; 656B: 83.9-93.3 mbsf; age: middle Pleistocene to early Pliocene.

Unit II consists of nannofossil ooze and less abundant foraminifer-nannofossil ooze, with minor zeolite-bearing sandy mud layers, volcanic glass, and micrite. Significant hiatuses occur within this unit in the lower Pleistocene (within nannofossil Zone NN19) and in the lower Pliocene (between nannofossil Zones NN12 and NN15). The hiatuses are more pronounced in Hole 656B than in 656A.

Unit III: Cores 107-656A-8R and 107-656B-5R to 107-656B-6R2, $120 \mathrm{~cm}$; depth: 656A: 169.7-179.1 mbsf; 656B: 93.3-105.6 mbsf; age: 656A: undetermined; 656B: early Pliocene.

Unit III is mostly homogeneous, structureless calcareous dolomitic muds. In Hole 656A, biogenic components are either absent or 


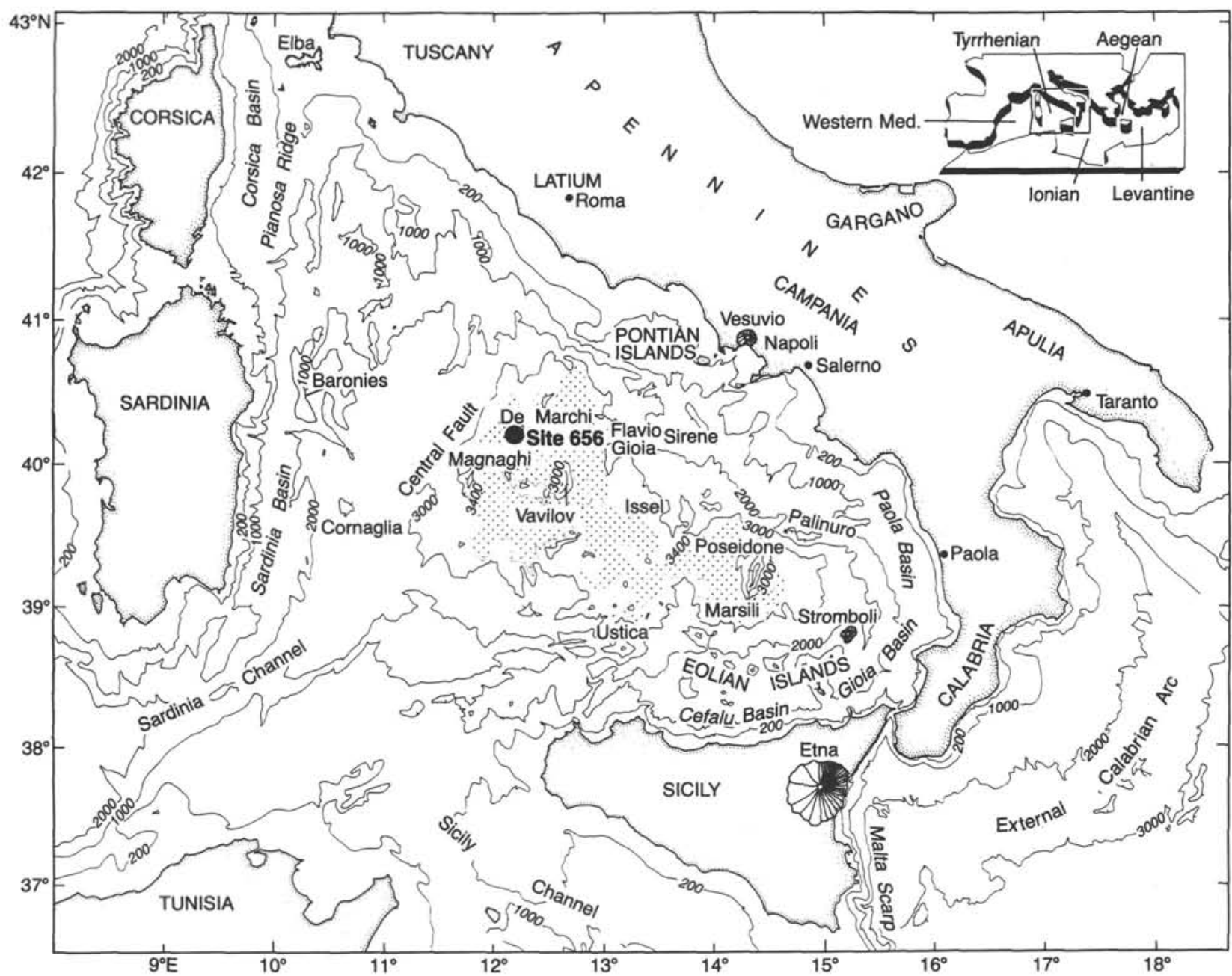

W

de Marchi Seamount

E

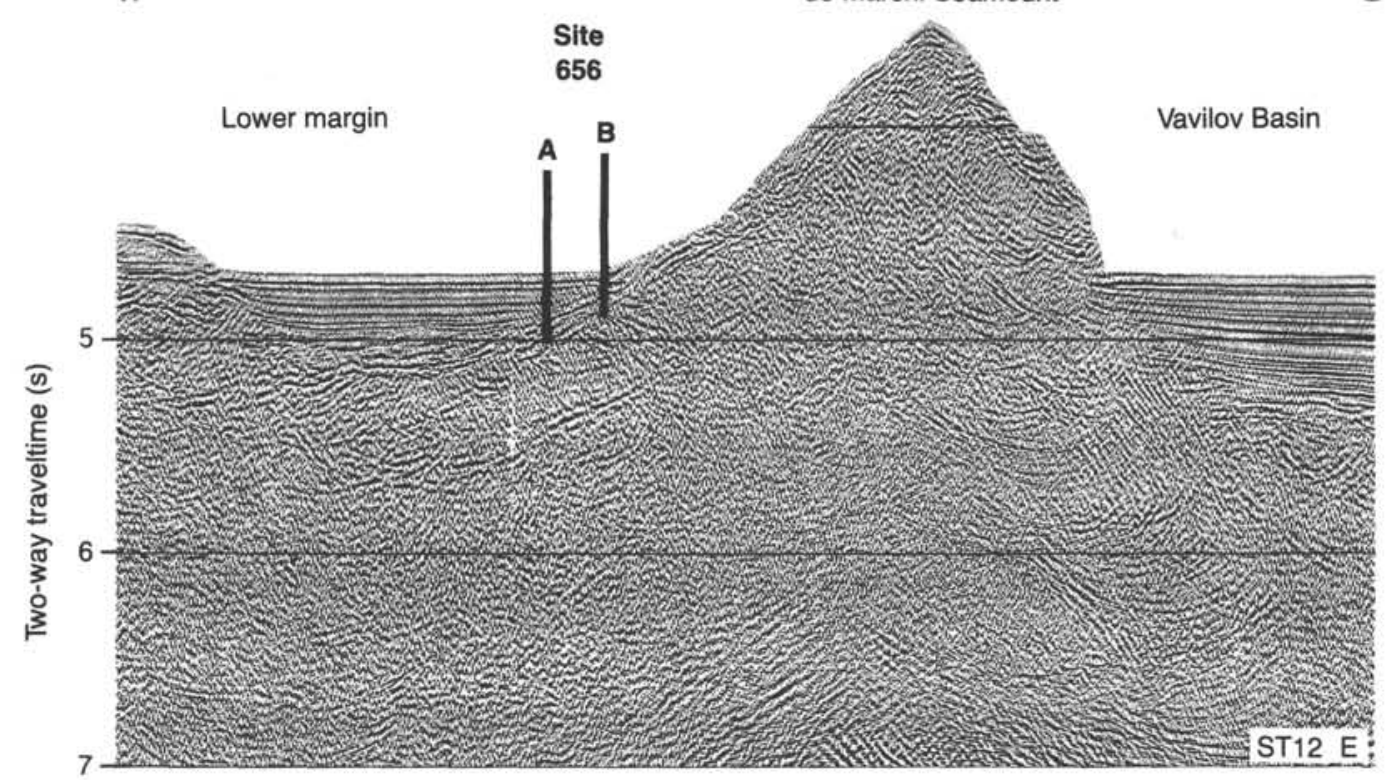

Figure 1. Location of Site 656 on a bathymetric map, at the base of the lower Sardinian margin, and location of Holes 656A and 656B on multichannel seismic line ST12. 


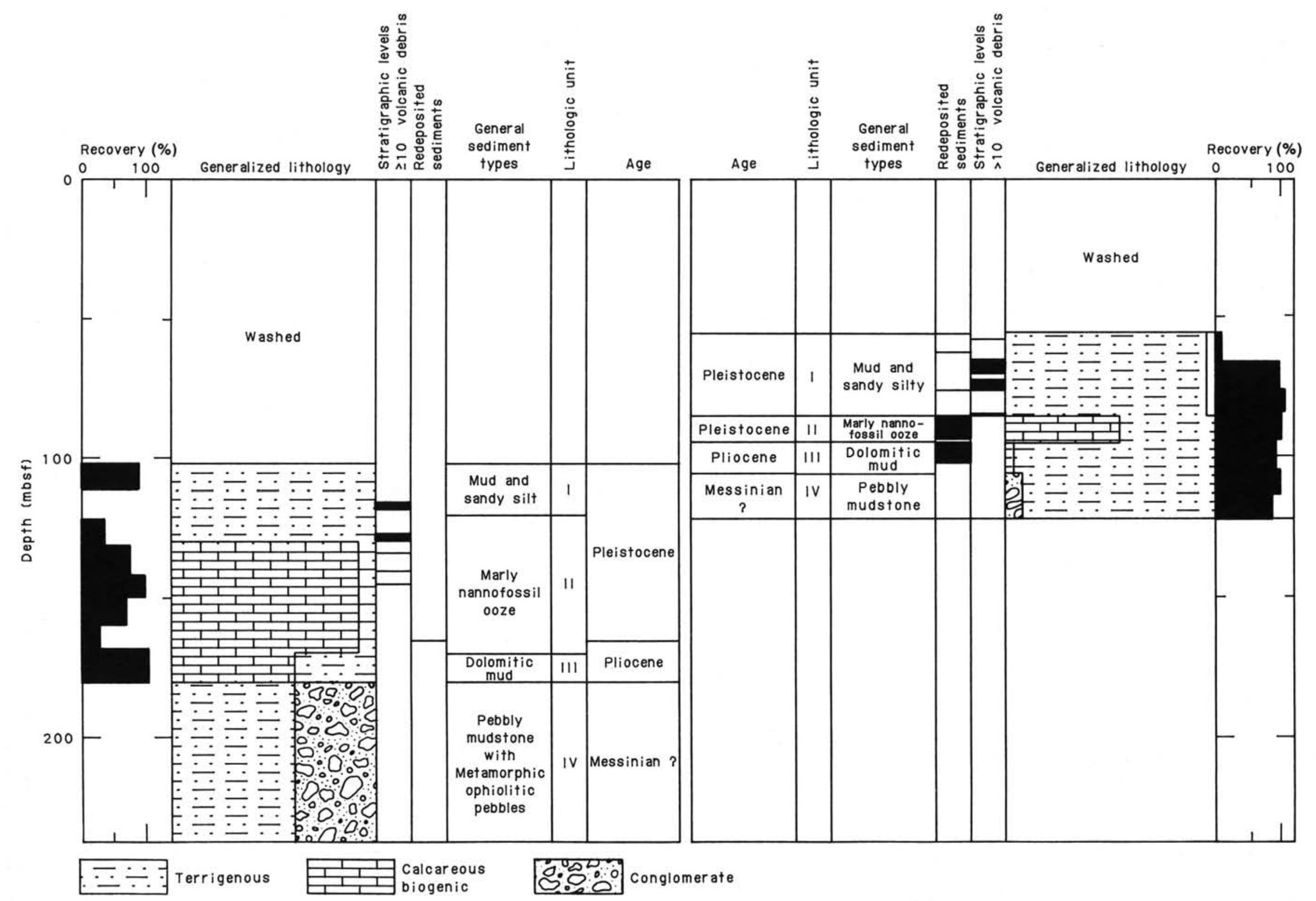

Figure 2. Schematic core logs for Holes 656A and 656B. 
extremely scarce and reworked; in Hole 656B some minor intervals of nannofossil oozes or nannofossil-rich calcareous oozes have been dated as early Pliocene (biozone NN12).

Unit IV: Cores 107-656A-9R to 107-656A-14R and 107-656B-6R2, $120 \mathrm{~cm}$, to 107-656B-7R, CC; depth: 656A: 179.1-236.4 mbsf; 656B: 105.6-121.8 mbsf; age: pre-Pliocene, possibly Messinian.

The major lithology of Unit IV is a conglomerate containing clasts of the following lithologies in one or both holes: greenish siltstone and fine-grained calcarenites, altered greenstone, red chert, white chert, silicified micritic limestone, limonitic clay, pyrite, chalcophyrite, galena, amphibole-rich rocks, mudstones, altered metagabbro (tremolite rich), amphibolite, metadolerite, and metaquartzite. The assembly of pebble lithologies at Hole 656B was less diverse than in Hole 656A. Where not washed away, the matrix is a red carbonate mud.

Summary: Units I and II were deposited in a normal open marine environment. However Unit II (from lower Pliocene to lower Pleistocene) is very condensed and contains at least two hiatuses (in Zone NN19 and in between Zones NN12 and NN16). Unit III represents a downstream transition in age and facies from lower Pliocene to probable Miocene and from open marine to continental environment. Unit IV is clearly a continental deposit which includes numerous basement rock types of alpine orogenic units.

\section{BACKGROUND AND OBJECTIVES}

\section{Regional Setting and Previous Work}

Site 656 is located on the western flank of the easternmost tilted fault block before the inferred transition between stretched continental and oceanic crust (Figs. 3 and 4). Site 655, with its basaltic basement, lies $25 \mathrm{~km}$ east, whereas Site 652 , with its thick syn-rift wedge of barren clastics, lies about $10 \mathrm{~km}$ northwest, in the next half-graben. The tilted block at Site 656, the Monte de Marchi, stands higher and broader than most of the fault blocks of the Sardinian margin. The ridge is asymmetrical, with a steep $\left(16^{\circ}\right)$ eastern flank, and a gentler $\left(10^{\circ}\right)$ western flank. Dredge hauls and observations from submersibles on the steep eastern flank of Monte de Marchi have shown that the basement contains probable Paleozoic and Mesozoic strata and low-grade metamorphic rocks including phyllites and metagabbros (Colantoni et al., 1981; Gennesseaux et al., 1986).

Seismic reflection profiles across the site (Fig. 4) show a thin, westward-thickening wedge of sediment tapering against the gentle western flank of the tilted block. This sedimentary wedge can be interpreted as a syn-rift sequence. The inferred syn-rift sediments are overlain by an onlapping sequence of subhorizontal reflectors, interpreted as post-rift turbidites. There is no suggestion of evaporites in the seismic data.

\section{Objectives}

With the completion of Site 655 , the proposed transect across the Sardinian margin and adjacent small basins had been achieved. With only a few operational days remaining in the cruise, there remained some ambiguity about the timing of the onset of rifting. Site 654 had been terminated for technical reasons in coarse conglomerates before reaching the pre-rift/syn-rift contact. Site 652 had reached the pre-rift/syn-rift contact, but the sediments were undatable by shipboard techniques. Therefore, the major objective of Site 656 was to try one last time to penetrate and date the pre-rift/syn-rift contact. The small thickness of the syn-rift sequence made this target practicable in a short amount of time.

A second objective was to identify the nature of the Messinian sediments, if any. Site 652, on what is now the lower Sardinian margin, had recovered a barren, clastic sequence interpreted as a Messinian lacustrine deposit, whereas Sites 653 and 654 , on what is now the middle and upper Sardinian margin, had recovered basinal evaporites. One interpretation of the distribution of these Messinian facies was that Site 652 had been higher standing than Sites 653 and 654 during the Messinian, and that there had been a drastic reorganization of the morphology of the western Tyrrhenian since the Messinian. Such a reorganization could be explained by a progressive southeastward migration of the locus of most intense rifting and subsidence on the evolving continental margin. This attractive scenario, however, depended on the inference that the barren sequence at Site 652 had been deposited in a basin which had little influx of seawater during the Messinian. If Messinian sediments were present at Site 656, their environment of deposition might support or refute the hypothesis that the lower Sardinian margin stood higher than the upper Sardinian margin during the Messinian.

The final objective of Site 656 was to examine the pre-rift evolution of the Tyrrhenian by documenting the environment of deposition of the tilted sediments between the acoustic basement and the syn-rift wedge. As originally proposed, Site TYR4 included several hundred meters of penetration into the pre-rift sequence, and pre-rift history was a major objective. However, when this second-priority site was squeezed in as the last site of the leg, this objective shrank to the less ambitious goal of determining the paleoenvironment and paleodepth of the site immediately before rifting.

\section{Site Selection}

The site was originally selected at shotpoint 2060 on site survey line ST12 on the grounds that this was the most downdip position at which one could reasonably expect to reach the basement/pre-rift contact by single-bit rotary drilling. A position farther downdip would consume too much drilling time; a position farther updip would have a less complete section with an unneccessarily large number of hiatuses.

When the site was recast as an opportunity to reach the prerift/syn-rift contact rather than the basement/pre-rift contact, the original position was retained. Moving updip seemed undesirable since it would introduce the same hiatuses we had been trying to avoid in selecting the original site; moving downdip was out of the question because it would have put the target out of reach in the time available.

When Hole 656A terminated prematurely in syn-rift sand and gravel, a second hole was sited updip from the first to try once more for the pre-rift sequence updip from the apparent pinch-out of the syn-rift wedge. Hole 656B was sited at the position where the unconsolidated turbidites above the tilted block were expected to be $50-70 \mathrm{~m}$ thick, just sufficient to comfortably stabilize the bottom-hole assembly and allow drilling into harder rocks with more than minimal weight on bit.

\section{OPERATIONS}

\section{Strategy}

As discussed under "Background and Objectives, Site Selection" section, this chapter, site TYR4 had been proposed as an 800-m deep hole to reach the pre-rift/basement contact, and then recast as a $280-\mathrm{m}$ deep hole to reach the pre-rift/syn-rift contact using the last few operational days of the cruise. The nature of the syn-rift sediment was unknown, but since experience at Site 652 suggested that it might be slow and difficult to drill, Site 656 was planned for rotary drilling. The upper portion of the sediment column had the by-now unmistakable seismic signature of Pleistocene turbidites. Since this stratigraphic interval had been continuously cored numerous times earlier in the leg, we obtained permission to wash down through the upper $100 \mathrm{~m}$ of the sediment column to allow more time for deeper penetration. No heat flow measurements or logging program was planned.

The approved site was located just downdip (i.e., west) of the pinch-out of the narrow wedge of syn-rift sediments. On bathymetric profiles, the approved site lay $550 \mathrm{~m}$ east of the contact 

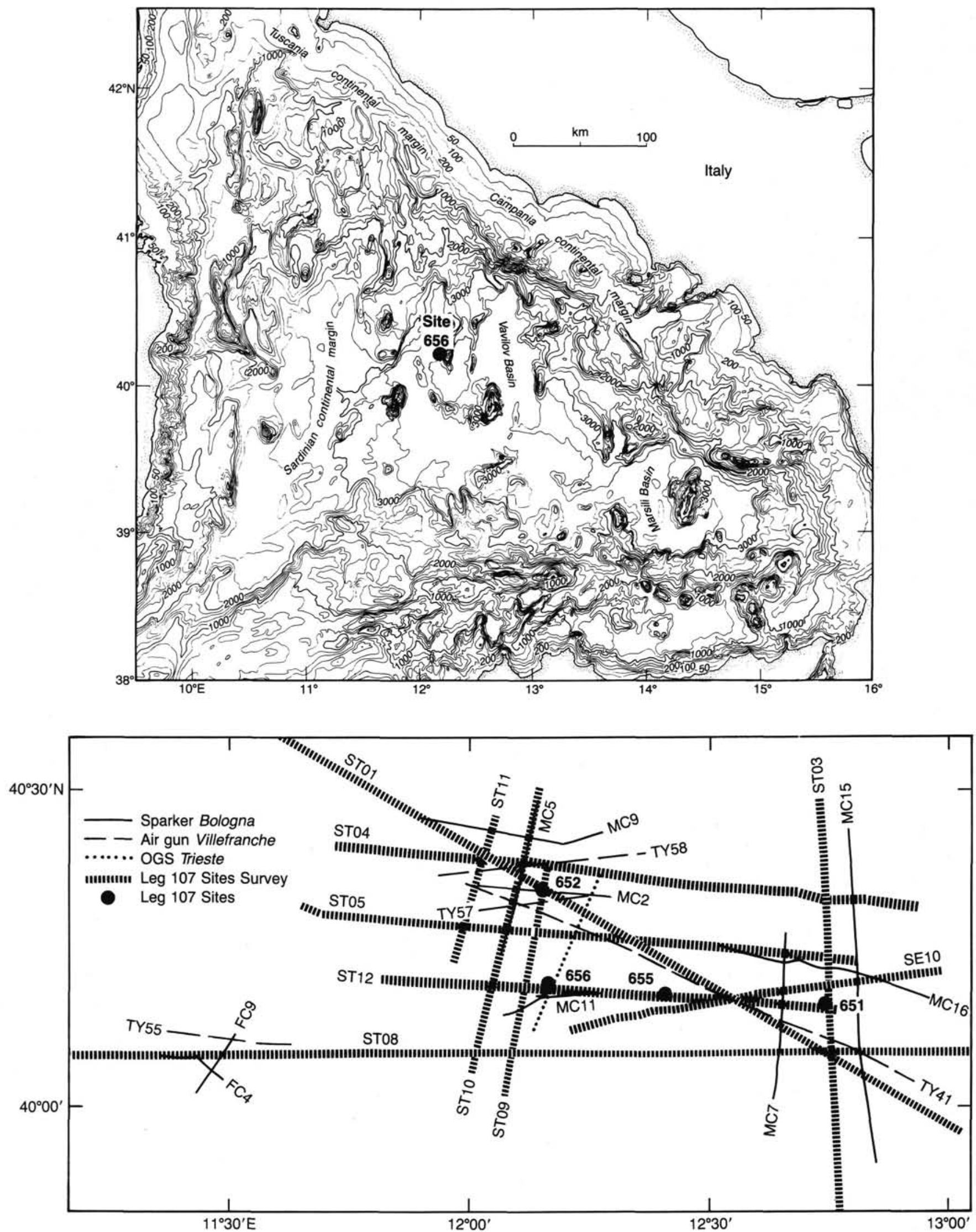

Figure 3. Location of Site 656 at the base of the lowermost Sardinian margin and track chart of seismic lines available in the vicinity of the site. 


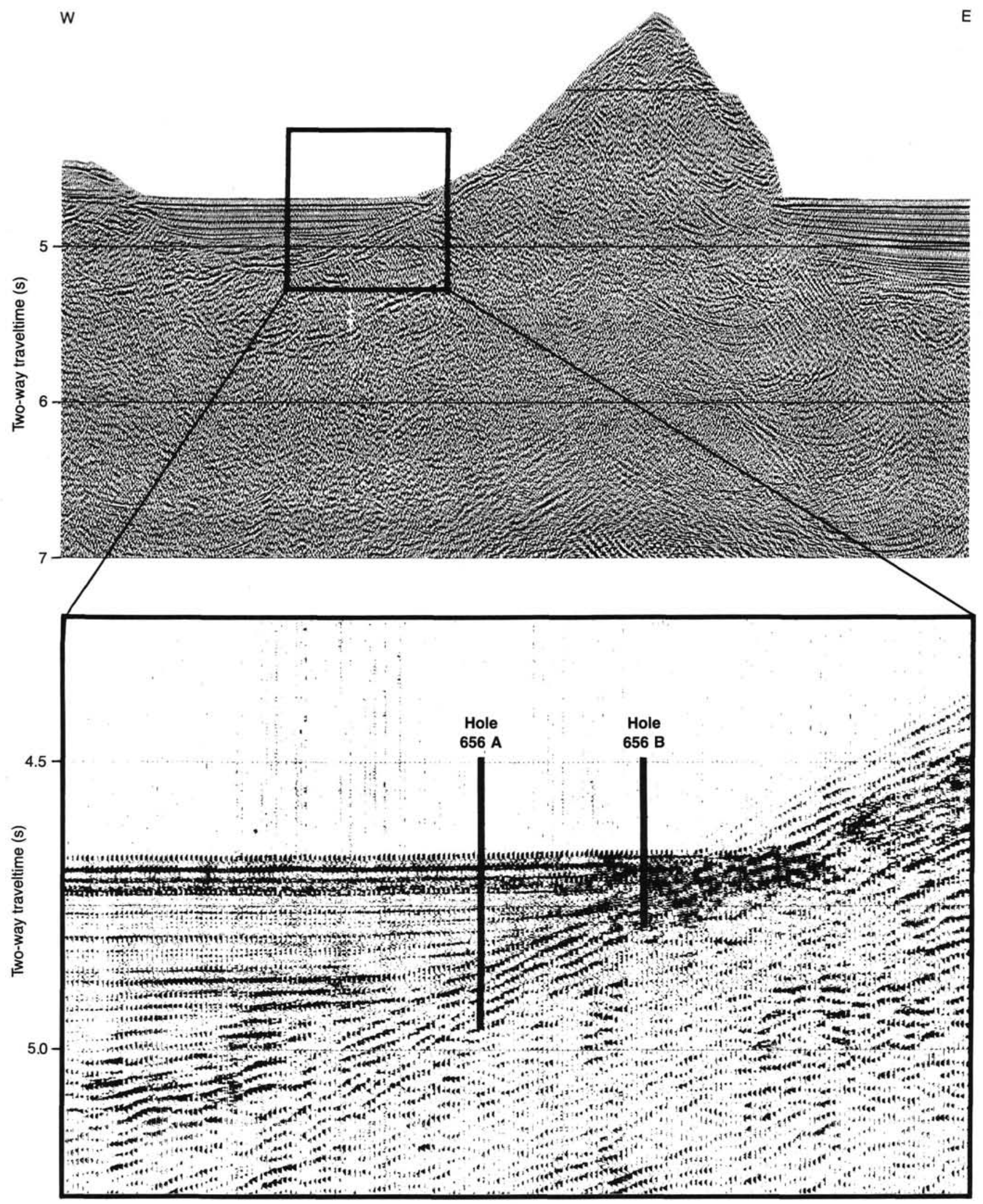

Figure 4. (Upper) MCS seismic line ST12 across the de Marchi Seamount, the easternmost tilted block before the transition from continental to oceanic crust. (Lower) Single-channel seismic profile along site approach line for Site 656. 
between the flat surface of the ponded turbidites and the sloping western flank of Monte de Marchi. The site approach would be straightforward, following site survey line ST12, on which both Sites 655 and 656 were located, from east to west over the crest of Monte de Marchi, and dropping the beacon when the ship reached the bathyal plain on the western side. We planned to drop the positioning beacon several hundred meters east of the planned drilling position so that the ship could be offset updip (i.e., eastward) to drill a second hole above the apparent pinch-out of the syn-rift wedge if the syn-rift sequence proved impossible to penetrate.

\section{Site Approach}

During the short transit from Site 655 and during the site approach to Site 656 , the ship was navigated using Loran C, which performed reliably. At 1435 on 13 February, the ship slowed to stream seismic gear. Good-quality seismic records were obtained beginning at 1455 , a few minutes before the streamer passed over the eastern flank of Monte de Marchi. The bathymetric profile over Monte de Marchi was similar to that from the site survey cruise. At 1559, the echo-sounder indicated that the ship had reached the contact between the seamount and the bathyal plain. The beacon was dropped $2 \mathrm{~min}$ after the contact, at 1601 , which should have been approximately $250 \mathrm{~m}$ west of the seamount flank and thus $300 \mathrm{~m}$ east of the approved position at the ship's speed of $4 \mathrm{kt}$. The Loran $C$ position at the time of the beacon drop was $40^{\circ} 10.96^{\prime} \mathrm{N}, 12^{\circ} 11.20^{\prime} \mathrm{E}$. The seismic line was carried on for another mile. A comparison between the site survey multichannel seismic profile and the site approach single channel profile showed good agreement between the geometry and depth of reflectors; the syn-rift wedge was found at the desired thickness at a point $400 \mathrm{~m}$ west of the beacon drop point.

Seismic gear was pulled at 1620 , and the ship reversed course to return to a position $400 \mathrm{~m}$ west of the beacon to begin dynamic positioning. An average of transit satellite fixes and GPS fixes while on station gave the following positions: $656 \mathrm{~A}: 40^{\circ} 11.06^{\prime} \mathrm{N}$, $12^{\circ} 11.03^{\prime} \mathrm{E}$; $656 \mathrm{~B}: 40^{\circ} 11.09^{\prime} \mathrm{N}, 12^{\circ} 11.45^{\prime} \mathrm{E}$. The Loran $\mathrm{C}$ position of $656 \mathrm{~B}$ was $40^{\circ} 11.01^{\prime} \mathrm{N}, 12^{\circ} 11.29^{\prime} \mathrm{E}$.

\section{Hole 656A}

The rotary core barrel (RCB) bottom-hole assembly for Hole $656 \mathrm{~A}$ was made up and run to the seafloor. The bottom-hole-assembly (BHA) included McCullough torque jars, which can be used to give a sharp upward jerk to free a stuck drill string; experience at Site 654 had warned that the danger of getting stuck in syn-rift sediments was considerable. A center bit was in place to allow washing/drilling through the Pleistocene sedimentary sequence previously cored nearby to a sub-bottom depth of 100 $\mathrm{m}$. The washing down process was routine after feeling for bottom carefully and defining the local mud line to be at $3606 \mathrm{~m}$ by slight indications on the weight indicator and heave compensator. The hole was spudded at 0100 on 14 February.

Coring began at $102.8 \mathrm{mbsf}$ and continued routinely through volcaniclastic and detrital sediments, then biogenic ooze, then barren dolomitic mud for the first eight cores. Recovery was fairly poor (average $34 \%$ ) in the detrital and volcaniclastic sediments, and much improved (average $82 \%$ ) in the biogenic oozes. Core $656 \mathrm{~A}-9 \mathrm{R}$ had complete recovery of a conglomerate with a clayey matrix, but then Core 656A-10R (at $197.8 \mathrm{mbsf}$ ) came up with only $0.4 \mathrm{~m}$ of sediment. The total recovery for Cores $656 \mathrm{~A}$ $10 \mathrm{R}$ through $656 \mathrm{~A}-14 \mathrm{R}$ was $0.96 \mathrm{~m}$ of loose rock fragments; the poor recovery is thought to indicate that a sandy matrix was washed away and/or lost during recovery. While preparing to drop the core barrel for Core 107-656A-15R, the pipe was found to be plugged with sediment inside and stuck in the hole. The torque jars were activated and the pipe was eventually freed after several up-jars and much working of the pipe. The plug of sediment inside the pipe was still in place, however, and further coring was impossible until it was dislodged.

The pipe was pulled clear of the seafloor at 0625 on 15 February. The vessel was offset $580 \mathrm{~m}$ east to the chosen position for Hole 656B (see "Background and Objectives, Site Selection" section, this chapter). During the move the pipe was left suspended about two stands above the seabed while attempting to clear out the plug and regain circulation. When the ship steadied up on the new location circulation still had not been achieved. The pipe was therefore pulled to the deck and the BHA was broken out collar-by-collar until the blockage was located. The entire outer core barrel was packed off with sand and mud. This material was washed away with a high-pressure hose and the center bit was landed in place before starting the pipe trip to the seafloor one last time to finish Hole 656B, the site, and the leg.

\section{Hole 656B}

The location for Hole 656B was chosen updip from the original site in a location where the seismic data indicated that the syn-rift sequence which had contained unstable sand would be thin or absent. As the superficial sediment cover would also be thinner the hole could only be safely washed to about $50 \mathrm{mbsf}$ without the risk of missing the sought-after contact. Thus the hole was drilled with a center bit to $55.5 \mathrm{mbsf}$ where the center bit was pulled and RCB coring commenced. The hole was officially spudded at 2100 on 15 February in $3606 \mathrm{~m}$ of water. Seven cores were taken to a sub-bottom depth of $121.8 \mathrm{mbsf}$. At that point, time for coring operations had expired and the final pipe trip out of the hole was begun in preparation for departure from the Tyrrhenian Sea. The coring summary for Site 656 appears in Table 1.

Table 1. ODP coring summary.

\begin{tabular}{|c|c|c|c|c|c|c|}
\hline $\begin{array}{l}\text { Core } \\
\text { no. }\end{array}$ & $\begin{array}{l}\text { Date } \\
\text { (Feb. } \\
1986 \text { ) }\end{array}$ & Time & $\begin{array}{l}\text { Sub-bottom } \\
\text { depths } \\
\text { (m) }\end{array}$ & $\begin{array}{c}\text { Cored } \\
(\mathrm{m})\end{array}$ & $\begin{array}{l}\text { Recovered } \\
\text { (m) }\end{array}$ & $\begin{array}{c}\text { Recovery } \\
(\%)\end{array}$ \\
\hline \multicolumn{7}{|l|}{ Hole A } \\
\hline $1 \mathrm{R}$ & 14 & 0500 & $102.8-112.2$ & 9.4 & 0.0 & 0.0 \\
\hline $2 \mathrm{R}$ & 14 & 0630 & $112.2-121.7$ & 9.5 & 9.0 & 94.7 \\
\hline $3 R$ & 14 & 0800 & $121.7-131.3$ & 9.6 & 0.1 & 1.3 \\
\hline $4 \mathrm{R}$ & 14 & 0915 & $131.3-141.0$ & 9.7 & 3.8 & 39.5 \\
\hline $5 \mathrm{R}$ & 14 & 1045 & $141.0-150.5$ & 9.5 & 7.3 & 76.3 \\
\hline $6 \mathrm{R}$ & 14 & 1215 & $150.5-160.1$ & 9.6 & 9.5 & 99.2 \\
\hline $7 \mathrm{R}$ & 14 & 1400 & $160.1-169.7$ & 9.6 & 6.8 & 70.9 \\
\hline $8 R$ & 14 & 1600 & $169.7-179.1$ & 9.4 & 2.7 & 28.6 \\
\hline 9R & 14 & 1800 & $179.1-188.2$ & 9.1 & 9.9 & 108.2 \\
\hline $10 \mathrm{R}$ & 14 & 2015 & $188.2-197.8$ & 9.6 & 0.4 & 4.2 \\
\hline $11 \mathrm{R}$ & 14 & 2200 & $197.8-207.5$ & 9.7 & 0.3 & 2.7 \\
\hline $12 \mathrm{R}$ & 15 & 0000 & $207.5-217.2$ & 9.7 & 0.1 & 1.4 \\
\hline $13 R$ & 15 & 0145 & $217.2-226.8$ & 9.6 & 0.1 & 1.1 \\
\hline $14 \mathrm{R}$ & 15 & 0315 & $226.8-236.4$ & 9.6 & 0.1 & 0.5 \\
\hline \multicolumn{7}{|l|}{ Hole B } \\
\hline IR & 16 & 0100 & $55.5-65.1$ & 9.6 & 0.7 & 7.0 \\
\hline $2 \mathrm{R}$ & 16 & 0230 & $65.1-74.8$ & 9.7 & 9.6 & 99.2 \\
\hline $3 \mathrm{R}$ & 16 & 0400 & $74.8-83.9$ & 9.1 & 9.6 & 105.8 \\
\hline $4 \mathrm{R}$ & 16 & 0545 & $83.9-93.3$ & 9.4 & 9.7 & 103.2 \\
\hline $5 \mathrm{R}$ & 16 & 0915 & $93.3-102.9$ & 9.6 & 8.8 & 92.0 \\
\hline $6 \mathrm{R}$ & 16 & 1130 & $102.9-112.3$ & 9.4 & 9.4 & 100.0 \\
\hline $7 \mathrm{R}$ & 16 & 1330 & $112.3-121.8$ & 9.5 & 8.5 & 89.9 \\
\hline
\end{tabular}




\section{LITHOSTRATIGRAPHY}

\section{HOLE 656A}

\section{Description of the Lithologic Units}

Hole $656 \mathrm{~A}$ was washed down to $102.8 \mathrm{~m}$ sub-bottom depth. The sedimentary sequence recovered underneath has been subdivided into the following lithologic units (Figs. 2 and 5):

Unit I: Cores 107-656A-1R to 107-656A-4R-1, $5 \mathrm{~cm}$; depth: 102.8-131.35 mbsf; thickness: $>28.55 \mathrm{~m}$; age: late Pleistocene.

This unit, characterized by poor recovery, essentially contains detrital and volcanogenic sediments with a subordinate fraction of biogenic carbonates. The detrital sediments are usually fine-grained, with some intervals of sandy mud and one 5$\mathrm{cm}$-thick interval of sand. The latter occurs in the top of Core $107-656 \mathrm{~A}-4 \mathrm{R}$ and is rich in zeolites that were possibly formed by alteration of volcanic glass. Volcanogenic grains occur throughout the dominant lithologies as fine fragments, never exceeding $9 \%$ of the total in smear slides. Crystal fragments of zircon, py- roxene, and blue amphibole occur in the coarser intervals. The blue amphibole indicates the presence of high-pressure/low-temperature metamorphic rocks that can be related to the regional eoalpine event. The biogenic fraction is subordinate, comprising foraminifers and nannofossils, in variable ratios, and minor sponge spicules.

Unit II: Cores 107-656A-4R-1, $5 \mathrm{~cm}$, to $107-656 \mathrm{~A}-7 \mathrm{R}, \mathrm{CC}$ : depth: 131.35-169.7 mbsf; thickness: $38.35 \mathrm{~m}$; age: middle Pleistocene to early Pliocene.

This unit essentially comprises biogenic oozes, mostly nannofossil oozes with subordinate foraminiferal-nannofossil oozes. Nannofossil Zones NN20 through NN12 are present in normal stratigraphic succession with, however, hiatuses (see "Biostratigraphy" section, this chapter). A variable noncarbonate fraction is present and is apparently more abundant in Cores 107-656A-4R and 107-656A-5R, than in Cores 107-656A-6R and $107-656 \mathrm{~A}-7 \mathrm{R}$. Cores $107-656 \mathrm{~A}-4 \mathrm{R}$ to the upper portion of $107-$ $656 \mathrm{~A}-6 \mathrm{R}$ are rather disturbed by drilling that has obliterated most sedimentary structures. The remaining parts of the unit

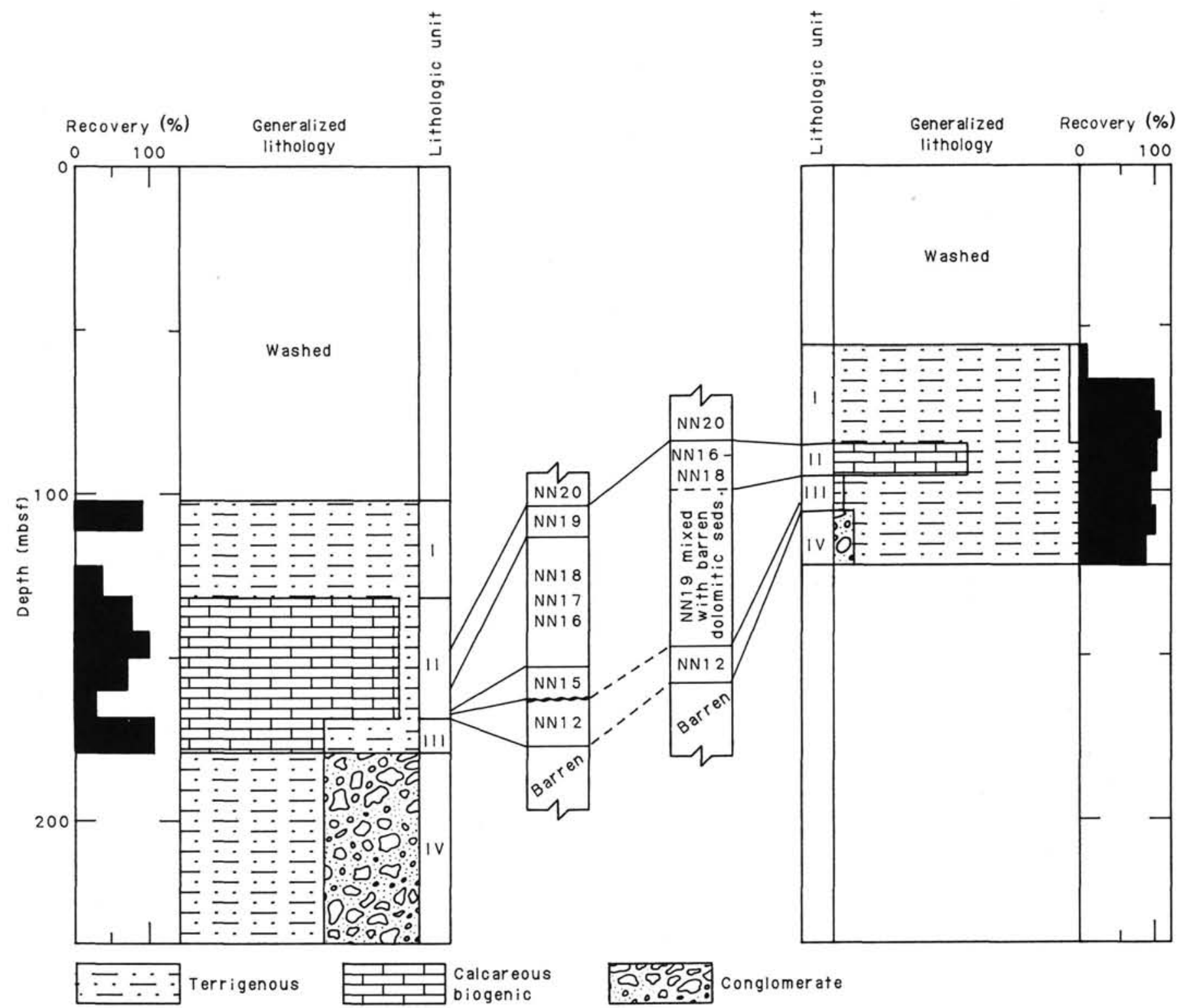

Figure 5. Summary of the sedimentary succession drilled at Holes 656A and 656B with detail of the main Pliocene-Pleistocene unconformities. Unit I: volcanogenic and detrital sediments. Unit II: nannofossil oozes. Unit III: dolomitic mud. Unit IV: conglomerate and red carbonate mud. 
are moderately burrowed, but also contain intervals showing subparallel color lamination. The colors are dominantly grayish in Cores 107-656A-4R and 107-656A-5R, becoming more brown or comprising brown-gray alternations in Cores 107-656A-6R and 107-656A-7R.

Zeolite-bearing sandy mud layers occur as discrete intervals at $107-656 \mathrm{~A}-5 \mathrm{R}-4,130 \mathrm{~cm}$, to $656 \mathrm{~A}-5 \mathrm{R}-5,30 \mathrm{~cm}$, at $107-656 \mathrm{~A}-$ $6 \mathrm{R}-3,110-130 \mathrm{~cm}$, to $656 \mathrm{~A}-6 \mathrm{R}-6,35-50 \mathrm{~cm}$, and in Core $656 \mathrm{~A}-7 \mathrm{R}$ (trace in Section 656A-7R-5). Volcanic glass appears occasionally in minor amounts $(0 \%-6 \%)$ among the dominant lithologies. Micrite is an important component from Core 107-656A-5R downward; Core 107-656A-5R also contains several indurated layers of nannofossil chalk as thick as $6 \mathrm{~cm}$.

Important sedimentary features are observed in Interval 107656A-6R-7, 13-20 cm, and in Interval 107-656A-7R-5, 17-32 $\mathrm{cm}$. These intervals exhibit very sudden color and lithology changes at a millimeter scale, together with the occurrence of sharp contacts and thin (millimeter) indurated layers (Fig. 6). The interval at 107-656A-7R-5, 17-32 cm (Fig. 6) has been examined in more detail using smear slides. The different layers are indurated and comprise calcareous sand, nannofossil ooze, and silty claystone. Spots of iron oxide-hydroxide mineral were observed within this interval and several centimeters below it. Such intervals may correspond either to very condensed sequences or to surfaces of nondeposition.

One slump or debris-flow interval was observed in 107-656A6R-5, 32-74 cm.

Unit III: Core 107-656A-8R; depth 169.7-179.1 mbsf; thickness $9.4 \mathrm{~m}$; age: pre-Pliocene (Messinian?).

This unit contains gray and dark gray dolomitic muds that are mostly calcareous, sometimes with a significant sand fraction. Biogenic components are either absent, or extremely scarce, and are reworked. The sediments are structureless and very homogenous. The unit terminates in the core catcher with a quartzfeldspar sandstone exhibiting a micritic-dolomicritic matrix. The lower boundary of the unit is rather artificial, since the top of the underlying Unit IV is essentially the same color and is also barren. In interval 107-656A-8R-2, 111-112 cm, one red colored very thin interval exhibits characteristics of the underlying Unit IV. We prefer to distinguish Unit III for two reasons: (1) the marked homogenity of the sediments and (2) the striking resemblance (apart from the absence of gypsum) with sediments of upper Messinian age cored at other sites (e.g., 652, 653).

Unit IV: Cores 107-656A-9R to 107-656A-14R; depth 179.1236.4 mbsf; thickness: $57.3 \mathrm{~m}$; age: pre-Pliocene.

Unit IV is characterized by (1) the presence of pebbles and cobbles, and (2) the very bright and deep red to brown colors of the dolomitic matrix. This unit is again barren. Core 107-656A$9 \mathrm{R}$ recovered a matrix-supported conglomerate with clasts embedded in a claystone matrix. By contrast, Cores 107-656A-10R to $107-656 \mathrm{~A}-14 \mathrm{R}$ recovered only rock pebbles without any fine detrital sediment. The absence of matrix is probably an artifact of drilling, similar to that recorded at the base of Site 654 .

Sulfides and oxides are abundant both in the matrix and as clasts. The clasts range from coarse sands to gravels and cobbles as follows: greenish siltstone and fine-grained calcarenite; altered greenstone; red chert, white chert; silicified micritic limestone; limonitic clay; crystalline sulfide clusters and fragments (pyrite, chalcopyrite, galena?); amphibole-rich rocks (large fibrous crystals); mudstones; altered metagabbro (tremolite-rich) (Figs. 7 and 8); amphibolites (sometimes banded); metadolerite; metaquartzite.

The main characteristics of these rocks are: (1) the very severe alteration, with replacement of most ferromagnesian minerals (e.g., tremolite-actinolite-talc-pyrophyllite paragenesis), and (2) the wide variety of sedimentary, metamorphic, and igneous rocks occurring therein.

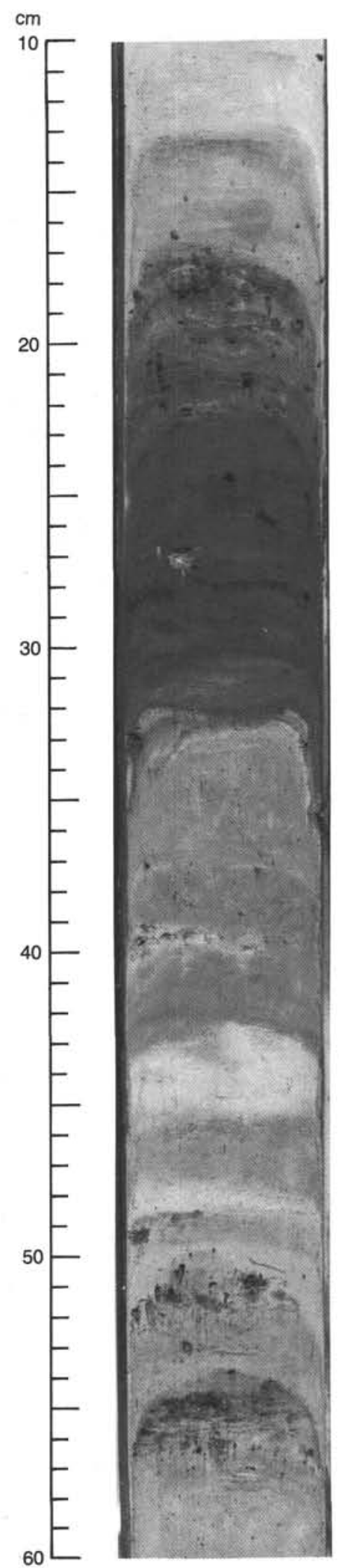

Figure 6. Close-up photograph of Core 107-656A-7R-5. The lower part of the photograph (below $35 \mathrm{~cm}$ ) comprises variably colored interlayered nannofossil ooze; $17-35 \mathrm{~cm}$ is composed of reddish semi-indurated nannofossil ooze; $10-16 \mathrm{~cm}$ is nannofossil ooze. The major hiatus between nannofossils Zones NN15 and NN12 occurs at $16 \mathrm{~cm}$. The curved lamination is drilling disturbance. 
$\mathrm{cm}$
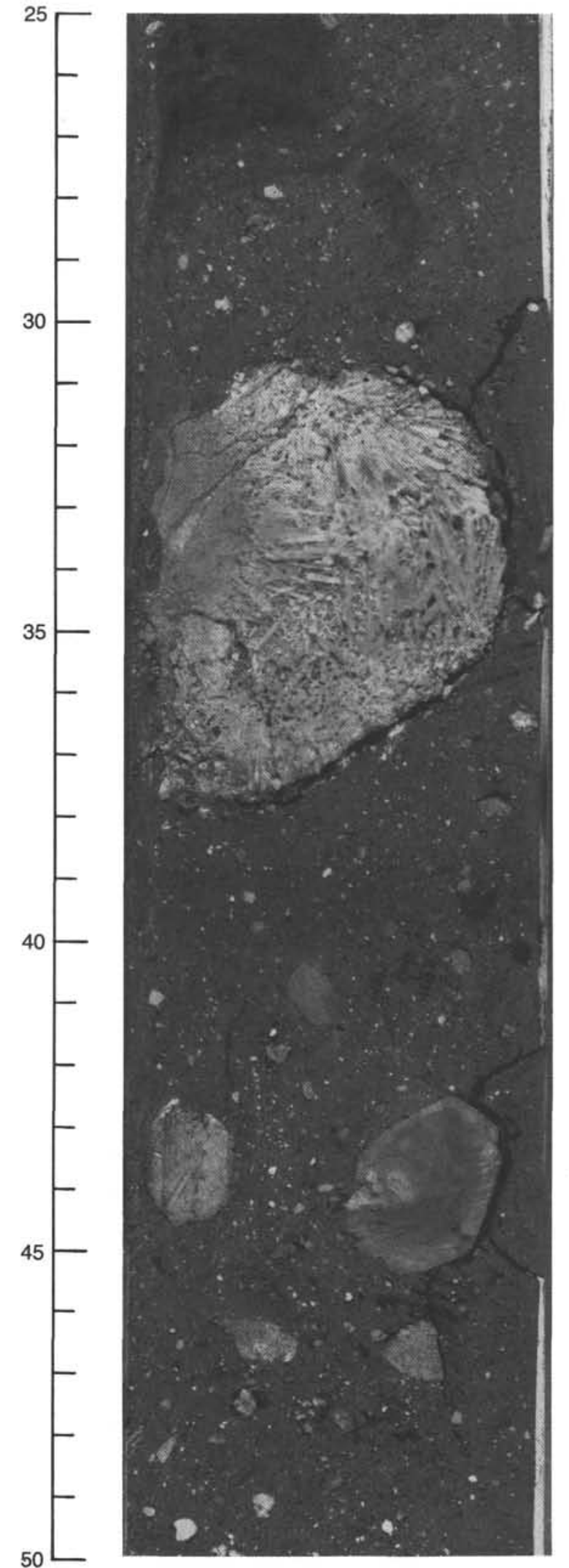

Figure 7. Close-up photograph of Core 107-656A-9R-7, showing the chaotic nature of the conglomerate making up Unit IV. The large white clast is made essentially by huge fibrous crystals of amphibole (actinolite-tremolite group) deriving from alteration of a mafic rock. $\mathrm{cm}$

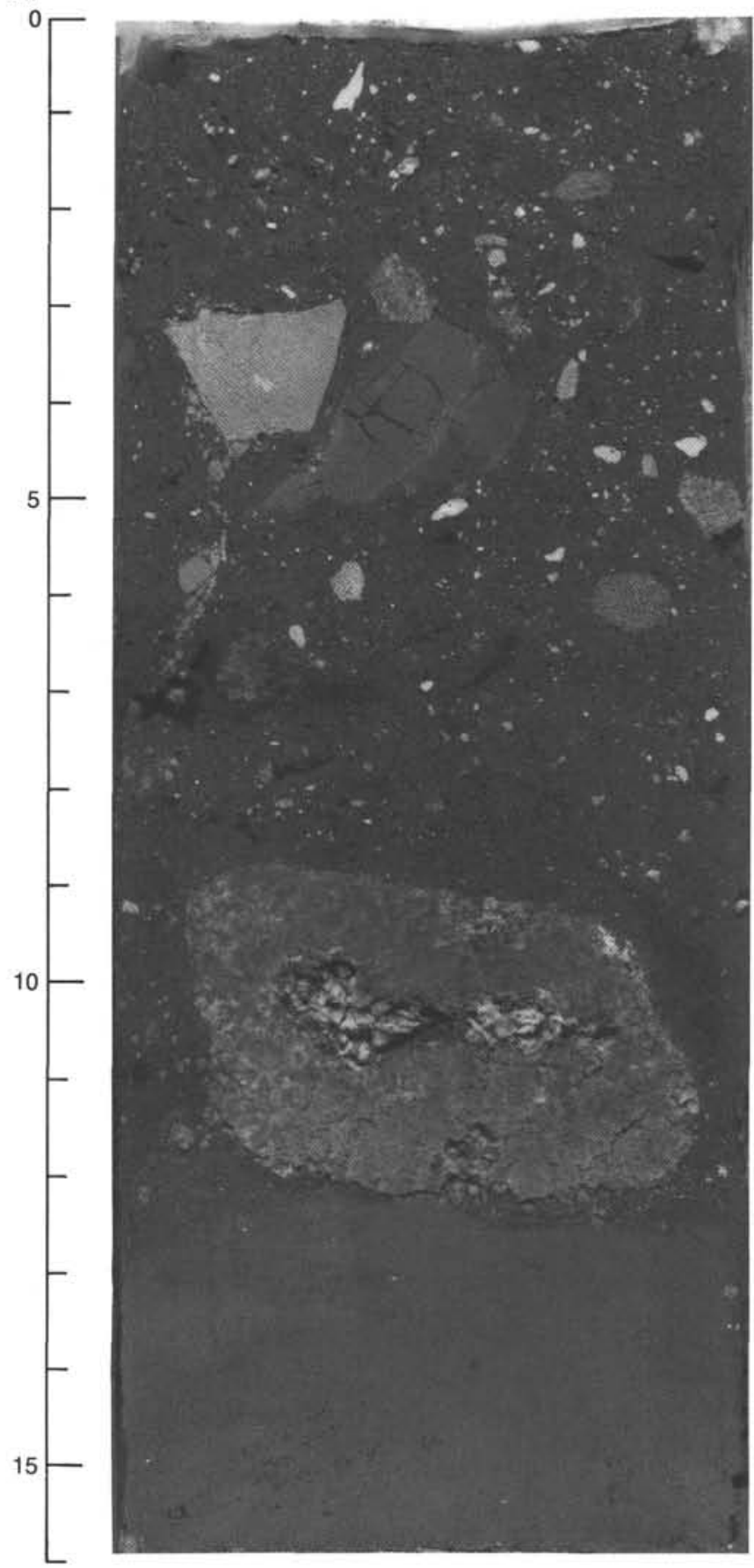

Figure 8. Close-up photograph of Core 107-656A-9R, CC; same general lithology as Figure 7. The largest clast is altered metagabbro; small whitish clasts are white cherts.

Most of the clasts, for example the greenstones, metagabbros, metadolerites, cherts, and some of the limestones, are consistent with provenance from an ophiolitic nappe terrane in which associated sedimentary rocks have been largely metamorphosed. Other rocks are quartzitic and calcarenitic. These rocks sometimes include reworked crystals of blue amphibole, with anellid fragments and possible oogons of Characeae. Reworking of continental sedimentary rocks, as well as metamorphic basement, is thus indicated. Sulfides occur in both the matrix and in the clasts and are usually euhedral or concretionary. The observations suggest that the sulfides formed essentially in situ. 


\section{Hole 656B}

\section{Description of Lithologic Units}

Hole 656B was located $580 \mathrm{~m}$ east of Hole 656A and was washed down to $55.5 \mathrm{mbsf}$. The sedimentary sequence recovered was strongly disturbed by drilling and has been subdivided into four lithologic units (Fig. 5).

Unit I: Cores 107-656B-1R to 656B-3R (55.5-83.9 mbsf); thickness: $>27.7 \mathrm{~m}$; age: late Pleistocene.

This unit mainly contains detrital and volcanogenic sediments, with a significant fraction of biogenic carbonates, interlayered with marly nannofossil oozes. As in Hole 656A, various heavy minerals occur: zircon, sphene, tourmaline, chlorite, and amphiboles, particularly blue amphiboles (glaucophane group). Pieces of red iron oxide-hydroxide material are frequent, especially at the top of Core 107-656B-3R (74.8 mbsf). Probable debris flows strongly disturbed by drilling occur at the top of Core 107-656B-1R (55.5 mbsf) and 656A-3R (74.8 mbsf).

Unit II: Core 107-656B-4R (83.9-93.3 mbsf); thickness: 9.4 $\mathrm{m}$; age: reworked Pliocene slump within Pleistocene sediments.

Unit II is dominated by biogenic oozes, mostly nannofossil oozes and foraminiferal-nannofossil oozes of late Pliocene age (NN16 to NN18) (see "Biostratigraphy" section, this chapter). Some thin detrital intervals contain altered volcanic ash (analcime-rich sand) with pyroxenes. Colors are strongly variable, dominantly pink; variations are olive yellow, reddish yellow, or light reddish brown. Red iron oxide-hydroxide material occurs at the top of the core $(83.9 \mathrm{mbsf})$ and in a very thin millimetric layer in Section 656B-4R-6 at $52 \mathrm{~cm}$. In Section 656B-4R-6 beneath $45 \mathrm{~cm}$ and in Section 656B-4R-7 there are alternations of dark gray dolomitic nannofossil oozes and light gray foraminiferal-nannofossil oozes. The sediments composing this whole unit are late Pliocene in age. They occur within a Pleistocene sequence. Unit II is thus interpreted as a slump.

Unit III: Core 107-656B-5R to 107-656B-6R-2, $120 \mathrm{~cm}$ (93.3105.6 mbsf); thickness: $12.3 \mathrm{~m}$; age: Pleistocene to early Pliocene.

This unit mainly contains varicolored dolomitic muds, ranging in color from light yellow, olive gray, pinkish gray, weak red, red to reddish brown. At the top of Core 107-656B-5R there is a unit highly disturbed by drilling which yielded nannofloras of the NN19 zone of Pleistocene age (see "Biostratigraphy" section, this chapter). Indurated limonite-cemented sandstones are frequent beneath this interval. At 107-656B-5R-6, $104 \mathrm{~cm}$, there is a minor occurrence (pebble?) of gypsiferous sand. The top of Core 107-656B-6R (Sections -1 and -2, 0-120 cm) shows minor intervals of gray or reddish brown nannofossil oozes, or of nannofossil-rich calcareous oozes that contain nannofloras of early Pliocene age (NN12, see "Biostratigraphy" section, this chapter).

Unit IV: From 107-656B-6R-2, $120 \mathrm{~cm}$, to 107-656B-7R, CC (105.6-121.8 mbsf); thickness: $16.2 \mathrm{~m}$; age: pre-Pliocene (Messinian or older).

The dominant sediment is a weak red carbonate mud containing scattered sand, gravel and pebble-sized clasts of iron oxide-hydroxides, sandstones, dolomites, marlstones, limestones, and gypsum-bearing sandstones.

\section{Comparisons Between Holes $656 \mathrm{~A}$ and $656 \mathrm{~B}$}

Although the general sequences are comparable in Holes 656A and 656B, we note several differences (Fig. 5):

1. The base of Unit $I$ is located at 131 mbsf in Hole 656A but at only $83.9 \mathrm{mbsf}$ at Hole 656B. Seismic reflection records, drilling characteristics, and comparison with Holes 650 and 651 suggest that the washed intervals contained sediments similar to those cored in Unit I. If correct, this Unit is approximately $47 \mathrm{~m}$ thinner updip in Hole 656B than downdip in Hole 656A.

2. The thickness of Unit II (biogenic oozes) decreases from $38.35 \mathrm{~m}$ in Hole 656A to $9.4 \mathrm{~m}$ in Hole 656B. In Hole 656A,
Unit II occurs in a normal stratigraphic sequence, although hiatuses and slumped intervals are present. In Hole 656B, Unit II comprises late Pliocene sediments that are completely reworked into Pleistocene sediments.

3. In Hole 656A, Unit III comprises barren dolomitic muds that underlie lower Pliocene nannofossil oozes (NN12). The situation in Hole 656B is more complicated. Comparable dolomitic muds occur beneath nannofossil oozes of NN19 age and above nannofossil oozes of NN12 age; also, the dolomitic mud contains some reworked gypsum inferred to be Messinian in age.

4. Emplacements of Units II and III of Hole 656B probably coincided in time to emplacement of the lower part of Unit II of Hole $656 \mathrm{~A}$, i.e., both were emplaced between nannofossil Zones NN12 and NN20. Unit III of Hole 656A has no apparent equivalent in time at Hole 656B, i.e., no subaqueous sediments below nannofosil Zone NN12.

5. Comparing the two holes, the middle and upper Pliocene sequences of nannofossil oozes of Hole 656A (Unit II; nannofossil Zones NN15-NN18) occupy the same stratigraphic positions as the barren dolomitic muds of reddish color that contain reworked gypsum in Hole 656B (part of Unit III); i.e., both fall immediately above apparently in-situ oozes of nannofossil Zone NN12. These observations are explicable if the dolomitic sediments in Hole 656B are interpreted as an allocthonous sequence reworked from beneath nannofossil Zone NN12.

6. Hole 656A exhibits two main hiatuses: between NN12 and NN15 in the lower Pliocene, and within NN19 in the lowermost Pleistocene. Hole 656B, instead, shows only one very large hiatus, extending from Zones NN12 to NN19.

7. Unit IV in Hole 656A is rich in large clasts composed mostly of altered igneous, metamorphic, and sedimentary rocks. Unit IV in Hole 656B is much richer in iron and in sandstone but contains fewer clasts. These clasts were exclusively derived from calcareous and terrigenous rocks.

\section{BIOSTRATIGRAPHY}

\section{Summary}

A Quaternary sequence of $160 \mathrm{~m}$ thickness is present at Hole $656 \mathrm{~A}$ of which $102.8 \mathrm{~m}$ was washed down. The series belongs almost entirely to the upper part of the Quaternary. The lower part is represented by only $2.40 \mathrm{~m}$. In Hole $656 \mathrm{~B}$ the incomplete Quaternary sequence, including slumped Pliocene sediments, has a thickness of about $100 \mathrm{~m}$ (Fig.9).

The Quaternary is underlain by a incomplete, very condensed Pliocene sequence in Cores 107-656A-7R and 107-656B-4R through $-6 \mathrm{R}$. The sediments are rich in well-preserved micro- and nannofossils.

In Hole 656A the Pliocene (NN12) is underlain by grey dolomitic mudstones (lithostratigraphic Unit III) barren of autochthonous fossils, containing common reworked nannoplankton from Cretaceous and Paleogene. These dolomitic mudstones probably belong to the Messinian. In Hole 656B, the Pliocene (NN12) is underlain by an iron-oxide-rich unit containing scattered pebbles (lithostratigraphic Unit IV).

\section{Planktonic Foraminifers}

Quaternary: A sequence of about $160 \mathrm{~m}$ thickness of Quaternary has been drilled at Hole 656A. Core 107-656A-1R was empty but in 107-656A-1R, CC (112.2 mbsf) a sample shows a warm temperate assemblage of the Globorotalia truncatulinoides excelsa Zone. The index species occurs from the top to 150.5 mbsf (107-656A-5R, CC). Between this level and 160.1 mbsf (107-656A-6R, CC) Globigerina cariacoensis was recognized. 

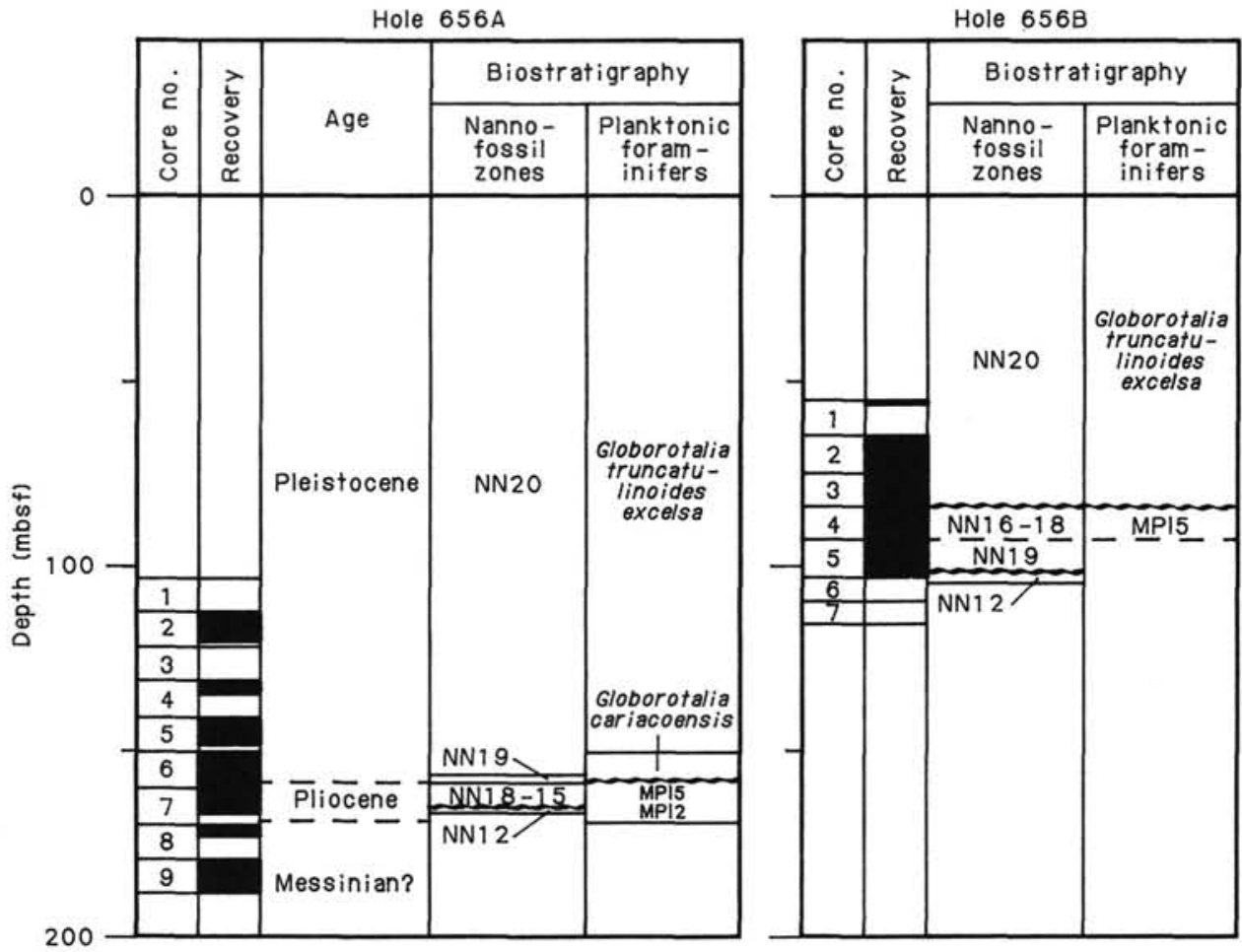

Figure 9. Summary of biostratigraphy determinations made at Site 656 .

Only one specimen of Globigerinoides obliquus has been found in 107-656A-6R, CC (160.1 mbsf).

At Site 656B, the Quaternary is more than $83.9 \mathrm{~m}$ thick. The first $55.5 \mathrm{~m}$ of sediments was washed. The Globorotalia truncatulinoides excelsa Zone is present from 107-656B-1R, CC (65.1 mbsf) until 107-656B-3R, CC (83.9 mbsf). Therefore, the upper part of Pleistocene is recognized. Globigerinoides obliquus extremus is common in 107-656B-4R, CC (93.3 mbsf).

Pliocene: At Hole 656A, the interval between 107-656A-7R$1,15-72 \mathrm{~cm}$, and 107-656A-7R-5, 57-59 cm (176.3 mbsf) must be referred to MP15 biozone. That means that a large gap exists including MPl5 (part), MPI6, and the lower part of the Pleistocene. Then Section 107-656A-7R, CC (169.7 mbsf) shows an assemblage of the lower Pliocene Globorotalia margaritae Zone (MPl2). Another long gap is present including MPl2 (upper part), MPl3, MPl4, and probably the base of MPl5. No foraminifers were recorded in Section 107-656A-8R, CC (179.1 mbsf). Downward, a red soil appears in Section 107-656A-9R, CC (188.2 mbsf). Shore-based studies may clarify the position of the Miocene/Pliocene boundary.

At Hole 656B, Section 107-656A-4R, CC (93.3 mbsf) shows an assemblage of the Globigerinoides elongatus (MP15) zone. No foraminifers were recorded at the top of Section 107-656A$5 \mathrm{R}, \mathrm{CC}$. Section 107-656A-6R, CC is pure dolomite without fossils (Messinian?)

\section{Benthic Foraminifers}

Benthic foraminifers in Site 656 occurred from $112 \mathrm{mbsf}$ to 170 mbsf of Hole 656A, and from 65 to 93 mbsf of Hole 656B. In the middle Pleistocene (112-150 mbsf in Hole 656A, and 65$84 \mathrm{mbsf}$ in Hole 656B), Articulina tubulosa and Parafissurina spp. are found as the autochthonous species. The upper part of this interval (112-131 mbsf in Hole 656A), which contains abundant volcanic materials, includes many displaced specimens. A similar assemblage can be found at 75 mbsf in Hole 656B.

At 160 mbsf of Hole 656A (Core 107-656A-6R, CC), Oridorsalis stellatus, Gyroidina altiformis, Cibicidoides kullenbergi, and $A$. tubulosa are found together with some reworked specimens including $C$. italicus and Sigmoilopsis schlumbergeri. The faunal association of autochthonous species is similar to that of the corresponding part of the Pleistocene in the previous holes.

In the samples of Sections 656A-7R-1 to 656A-7R-4 in Hole $656 \mathrm{~A}$ and Sections 656B-4R-2 to 656B-4R-7 in Hole 656B, $O$. stellatus, Karreriella bradyi, Gyroidina spp., and C. robertsonianus are present. They are also associated with some reworked specimens of $C$. italicus.

The samples at 167 and 170 mbsf in Hole 656A (Cores 107656A-7R-5, 79-81 cm, and 656A-7R-5, CC) are characterized by occurrence of $O$. stellatus, $C$. italicus, and Siphonina reticulata. This fauna resembles those in and below the interval of maximum abundance of species diversity in the MPl4 biozone of Pliocene sequences.

\section{Nannoplankton}

At Hole 656A the upper $102.8 \mathrm{~m}$ of Pleistocene turbidites was washed down. The Gephyrocapsa oceanica zone (NN20) was determined from Core 107-656A-1R to Sample 107-656A$6 \mathrm{R}-5,30 \mathrm{~cm}$ (102.8-156.8 mbsf) underlain by a very condensed or incomplete sequence belonging to the Pseudoemiliania lacunosa zone (NN19) from Samples 107-656A-6R-5, $83 \mathrm{~cm}$, to 107656A-6R-7, $12 \mathrm{~cm}$ (157.0-160.0 mbsf). The sediments are generally rich in nannoplankton. However, they are diluted by detrital carbonate, volcanic ash, and reworked species within the turbiditic layers.

The small Gephyrocapsa zone was recognized at Hole 656A from Samples 107-656A-6R-6, $139 \mathrm{~cm}$, to 107-656A-6R-7, 12 $\mathrm{cm}$. It is supposed that the greatest part of the lower NN19 is not represented. The sample taken from a reddish-brown indurated layer (Sample 107-656A-6R-7, $14 \mathrm{~cm}$ ) is poor in nannoplankton due to dissolution. This horizon is underlain by nannoplankton-rich sediments of Zone NN19. The reddish-brown layer might indicate an interval of nondeposition.

The Pliocene/Pleistocene boundary at Hole $656 \mathrm{~A}$ lies between Samples 107-656A-6R-7, $12 \mathrm{~cm}$, and 107-656A-6R-7, 26 
$\mathrm{cm}$ (at about $160.0 \mathrm{mbsf}$ ), recognized by the extinction of $C y$ clococcolithus macintyrei. At Hole 656B this boundary was determined between Cores 107-656B-3R and 107-656B-4R.

The sequence from Samples 107-656A-7R-1, $96 \mathrm{~cm}$, to $107-$ $656 \mathrm{~A}-7 \mathrm{R}-4,60 \mathrm{~cm}$, belongs to the upper Pliocene (nannoplankton Zones NN18 to upper NN16). Discoasters are absent or are very rare. The lower part of Zone NN16 seems to be missing.

Nannoplankton are abundant and well preserved in Zone NN15 (Reticulofenestra pseudombilica zone) from Samples 107656A-7R-4, $90 \mathrm{~cm}$, to 107-656A-7R-5, $8 \mathrm{~cm}$. Discoasters are common. This zone is again separated from the underlying lower Pliocene (Zone NN12) by a reddish-brown indurated layer (nondeposition) poor in nannoplankton due to dissolution.

Zone NN12 (Amaurolithus tricorniculatus zone) is present from Samples 107-656A-7R-5, $15 \mathrm{~cm}$, to 107-656A-7R, CC.

In Hole 656B, Zone NN20 (Pleistocene) is present from Core 107-656B-1R to Core 107-656B-3R, CC (55.5-84.0 mbsf). It is underlain by slumped upper Pliocene sediments (NN16-NN18) in Core 107-656B-4R equivalent to lithostratigraphic Unit II. Sediments of Zone NN19 (lower Pleistocene) mixed with Pliocene and barren dolomitic mud were encountered in Core 107656A-5R, underlain by lower Pliocene deposits of Zone NN12 in Core 107-656B-6R-1.

The lowest portion of both holes contains red to brown clay with pebbles and conglomerates of different lithologies. These deposits are inferred to represent the continental facies of the Messinian.

\section{PHYSICAL PROPERTIES}

\section{Introduction}

Cores from both holes were used for shipboard analysis. Physical properties measured at Site 656 include GRAPE density from full round core sections, vane shear strength, compressional-wave velocity, and index properties (porosity, bulk density, and grain density) from split sections. Due to drilling disturbances, shear strength measurements were done on only some cores of Holes 656A and 656B. Tables 2 through 7 list Site 656 physical-properties measurements.

The methods of analysis are described in the "Explanatory Notes" chapter, this volume.

\section{Results}

\section{Index Properties and Compressional Velocity}

Porosity, bulk density, grain density, and compressional velocity from Holes 656A and 656B are listed in Tables 2 through 5 and are shown in Figures 10 and 11. Because the upper sec-

Table 2. Physical properties index, Hole 656A.

\begin{tabular}{lccccc}
\hline $\begin{array}{c}\text { Core } \\
\text { section }\end{array}$ & $\begin{array}{c}\text { Interval } \\
\text { or piece } \\
\text { no. }\end{array}$ & $\begin{array}{c}\text { Depth } \\
\text { sub-bottom } \\
(\mathrm{m})\end{array}$ & $\begin{array}{c}\text { Bulk } \\
\text { density } \\
\left(\mathrm{g} / \mathrm{cm}^{3}\right)\end{array}$ & $\begin{array}{c}\text { Porosity } \\
(\%)\end{array}$ & $\begin{array}{c}\text { Grain } \\
\text { density } \\
\left(\mathrm{g} / \mathrm{cm}^{3}\right)\end{array}$ \\
\hline 2R-3 & $44-47$ & 115.64 & 1.70 & 63.4 & 2.76 \\
2R-6 & $44-48$ & 120.14 & 1.71 & 58.8 & 2.68 \\
4R-1 & $59-62$ & 131.89 & 1.80 & 57.8 & 2.72 \\
4R-3 & $31-34$ & 134.61 & 1.79 & 60.7 & 2.77 \\
6R-5 & $88-90$ & 157.38 & 1.83 & 60.9 & 3.05 \\
6R-7 & $22-25$ & 159.72 & 1.97 & 63.1 & 2.78 \\
7R-4 & $100-103$ & 165.60 & 1.85 & 54.3 & 2.72 \\
7R-5 & $5-8$ & 166.15 & 1.84 & 56.2 & 2.77 \\
8R-1 & $48-52$ & 170.18 & 2.26 & 33.9 & 2.77 \\
8R-2 & $104-107$ & 172.24 & 2.36 & 29.9 & 2.91 \\
9R-3 & $1-7$ & 182.11 & 2.12 & 56.7 & 3.40 \\
9R-7 & $1-7$ & 188.11 & 2.35 & 45.8 & 3.21 \\
\hline
\end{tabular}

Table 3. Physical properties index, Hole 656B.

\begin{tabular}{lccccc}
\hline $\begin{array}{c}\text { Core } \\
\text { section }\end{array}$ & $\begin{array}{c}\text { Interval } \\
\text { or piece } \\
\text { no. }\end{array}$ & $\begin{array}{c}\text { Depth } \\
\text { sub-bottom } \\
(\mathrm{m})\end{array}$ & $\begin{array}{c}\text { Bulk } \\
\text { density } \\
\left(\mathrm{g} / \mathrm{cm}^{3}\right)\end{array}$ & $\begin{array}{c}\text { Porosity } \\
(\%)\end{array}$ & $\begin{array}{c}\text { Grain } \\
\text { density } \\
\left(\mathrm{g} / \mathrm{cm}^{3}\right)\end{array}$ \\
\hline 1 R-1 & $21-24$ & 55.72 & 1.50 & 74.1 & 2.51 \\
2R-1 & $15-18$ & 65.26 & 1.67 & 66.2 & 2.70 \\
2R-7 & $50-53$ & 74.62 & 1.76 & 60.7 & 2.77 \\
3R-6 & $129-132$ & 83.60 & 1.81 & 58.9 & 2.93 \\
4R-6 & $100-103$ & 92.40 & 2.15 & 42.1 & 2.85 \\
5R-6 & $7-10$ & 100.90 & 1.70 & 35.8 & 2.03 \\
6R-7 & $27-30$ & 112.20 & 2.14 & 47.8 & 2.94 \\
7R-6 & $4-10$ & 119.90 & 2.00 & 53.8 & 3.09 \\
7R-6 & $74-77$ & 120.57 & 2.04 & 51.8 & 3.11 \\
\hline
\end{tabular}

Table 4. Compressional velocity, Hole 656A.

\begin{tabular}{cccc}
\hline $\begin{array}{c}\text { Core } \\
\text { section }\end{array}$ & $\begin{array}{c}\text { Interval } \\
(\mathrm{cm})\end{array}$ & $\begin{array}{c}\text { Depth } \\
\text { sub-bottom } \\
(\mathrm{m})\end{array}$ & $\begin{array}{c}\text { Compressional } \\
\text { velocity } \\
(\mathrm{km} / \mathrm{s})\end{array}$ \\
\hline 2R-3 & $44-47$ & 115.64 & 1.525 \\
$2 \mathrm{R}-6$ & $44-48$ & 120.14 & 1.627 \\
$4 \mathrm{R}-1$ & $59-62$ & 131.89 & 1.493 \\
$4 \mathrm{R}-3$ & $31-34$ & 134.61 & 1.564 \\
$5 \mathrm{R}-4$ & $86-89$ & 146.40 & 1.610 \\
$6 \mathrm{R}-5$ & $88-90$ & 157.38 & 1.564 \\
$6 \mathrm{R}-7$ & $22-25$ & 159.72 & 1.637 \\
$7 \mathrm{R}-4$ & $100-103$ & 165.60 & 1.665 \\
$7 \mathrm{R}-5$ & $5-8$ & 166.15 & 1.632 \\
$8 \mathrm{R}-1$ & $48-52$ & 170.18 & 1.927 \\
$8 \mathrm{R}-2$ & $104-107$ & 172.24 & 1.815 \\
\hline
\end{tabular}

Table 5. Compressional velocity, Hole 656B.

\begin{tabular}{lccc}
\hline $\begin{array}{c}\text { Core } \\
\text { section }\end{array}$ & $\begin{array}{c}\text { Interval } \\
(\mathrm{cm})\end{array}$ & $\begin{array}{c}\text { Depth } \\
\text { sub-bottom } \\
(\mathrm{m})\end{array}$ & $\begin{array}{c}\text { Compressional } \\
\text { velocity } \\
(\mathrm{km} / \mathrm{s})\end{array}$ \\
\hline 2R-1 & $15-18$ & 65.26 & 1.602 \\
2R-7 & $50-53$ & 74.62 & 1.655 \\
3R-6 & $129-132$ & 83.60 & 1.573 \\
$4 \mathrm{R}-3$ & $146-150$ & 88.40 & 1.621 \\
$4 \mathrm{R}-6$ & $100-103$ & 92.40 & 1.720 \\
$5 \mathrm{R}-6$ & $7-10$ & 100.90 & 1.656 \\
6R-7 & $27-30$ & 112.20 & 1.655 \\
7R-6 & $74-77$ & 120.55 & 1.691 \\
\hline
\end{tabular}

tions of both holes were partially washed and because of severe drilling disturbances, few results are available.

Grain density is variable from 2.68 to $3.40 \mathrm{~g} / \mathrm{cm}^{3}$ in Hole $656 \mathrm{~A}$ and from 2.03 to $3.11 \mathrm{~g} / \mathrm{cm}^{3}$ in Hole $656 \mathrm{~B}$. However, the red continental matrix of sedimentary Unit IV has significantly higher grain densities $\left(2.9-3.4 \mathrm{~g} / \mathrm{cm}^{3}\right)$ than Units I, II, or III. This may be due to the presence of iron oxides or heavy minerals.

The bulk density values are in good agreement with the porosity values and reflect the same trend along the two holes. Hole 656A shows homogeneous bulk densities $\left(1.8 \mathrm{~g} / \mathrm{cm}^{3}\right)$ and porosity $(60 \%)$ down to $166 \mathrm{mbsf}$. The bulk density is then sensibly higher (average $2.27 \mathrm{~g} / \mathrm{cm}^{3}$ ) in the two deepest lithostratigraphic units. Nevertheless, those two units can be distinguished with the porosity data: $29.9 \%-33.9 \%$ for Unit III, $51.8 \%$ $53.8 \%$ for Unit IV.

Hole 656B presents a regular decrease of porosity from $74 \%$ at $55.72 \mathrm{mbsf}$ to $35 \%$ at $100.90 \mathrm{mbsf}$, corresponding to lithostratigraphic Units I, II, and III. As in Hole 656A, higher porosity values were noted in lithostratigraphic Unit IV (average $51.1 \%$ ). The few bulk density data available seem to underline each of the sedimentary units: A regular increase (1.50-1.81 g/ 


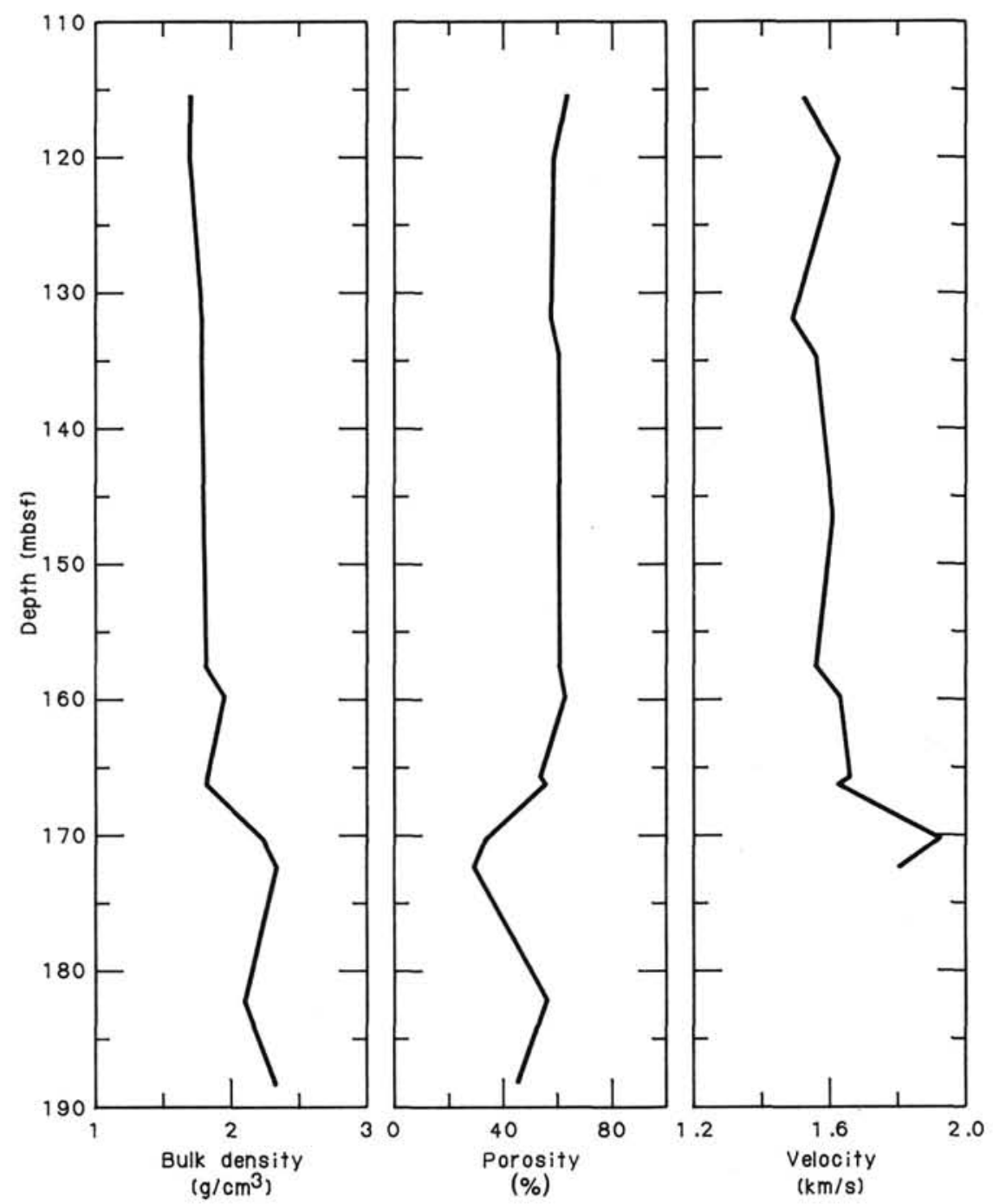

Figure 10. Bulk density, porosity, and velocity vs. depth at Hole 656A.

$\mathrm{cm}^{3}$ ) was observed in lithostratigraphic Unit $\mathrm{I}$, a high value $\left(2.15 \mathrm{~g} / \mathrm{cm}^{3}\right)$ was noted in lithostratigraphic Unit II, a lower value $\left(1.70 \mathrm{~g} / \mathrm{cm}^{3}\right)$ characterizes Unit III, and Unit IV presents sensibly higher data (average $2.06 \mathrm{~g} / \mathrm{cm}^{3}$ ).

Compressional velocity data of Hole $656 \mathrm{~A}$ show a slightly increasing trend down to $166 \mathrm{mbsf}$. In this interval, data range from 1.49 to $1.66 \mathrm{~km} / \mathrm{s}$. The two deepest samples gave higher velocities (1.93 and $1.85 \mathrm{~km} / \mathrm{s})$ and correspond to lithostratigraphic Unit III. Material of Unit IV was too soft to be measured.

Few data from Hole 656B are available. Nevertheless, two trends can be noted: from 65.26 to 88.40 mbsf (average 1.613 $\mathrm{km} / \mathrm{s}$ ) and from $92.4 \mathrm{mbsf}$ to the bottom of the hole (average $1.681 \mathrm{~km} / \mathrm{s})$. Due to drilling disturbances the velocities of lithostratigraphic Units III and IV were probably underestimated.

\section{Shear Strength}

Due to drilling disturbances, few measurements were done at Site 656 (Fig. 12 and Tables 6 and 7). The results are very heterogeneous and remain difficult to interpret.

\section{Conclusion}

Although few data are available for this site, some conclusions can be noted:
1. Lithostratigraphic Units I and II cannot be distinguished by their physical properties in either hole.

2. Lithostratographic Unit III was distinguished by its low porosity values in both holes.

3. In both holes lithostratigraphic Unit IV presents higher grain densities and higher porosities than lithostratigraphic Unit III. Those physical properties are probably related to the continental nature of this unit.

\section{DISCUSSION AND CONCLUSION}

Site 656 was handicapped by time constraints and technical problems. Nonetheless, the site succeeded in documenting the presumed Messinian facies, and thereby substantiated the hypothesis that the lower Sardinia margin was relatively highstanding during the Messinian.

\section{Depositional Environment}

The Pliocene-Pleistocene sediments (Units I and II at both Holes 656A and 656B) were deposited in a normal open marine environment. As in Sites 650 and 651, the upper Pleistocene sediments (Unit I at Holes 656A and 656B) record significant detrital and volcanogenic input, with corresponding high accumulation rates. During the early Pleistocene/Pliocene (Unit II at Holes A and B) the sedimentation was mostly biogenic and characterized by lower accumulation rates. The difference in 


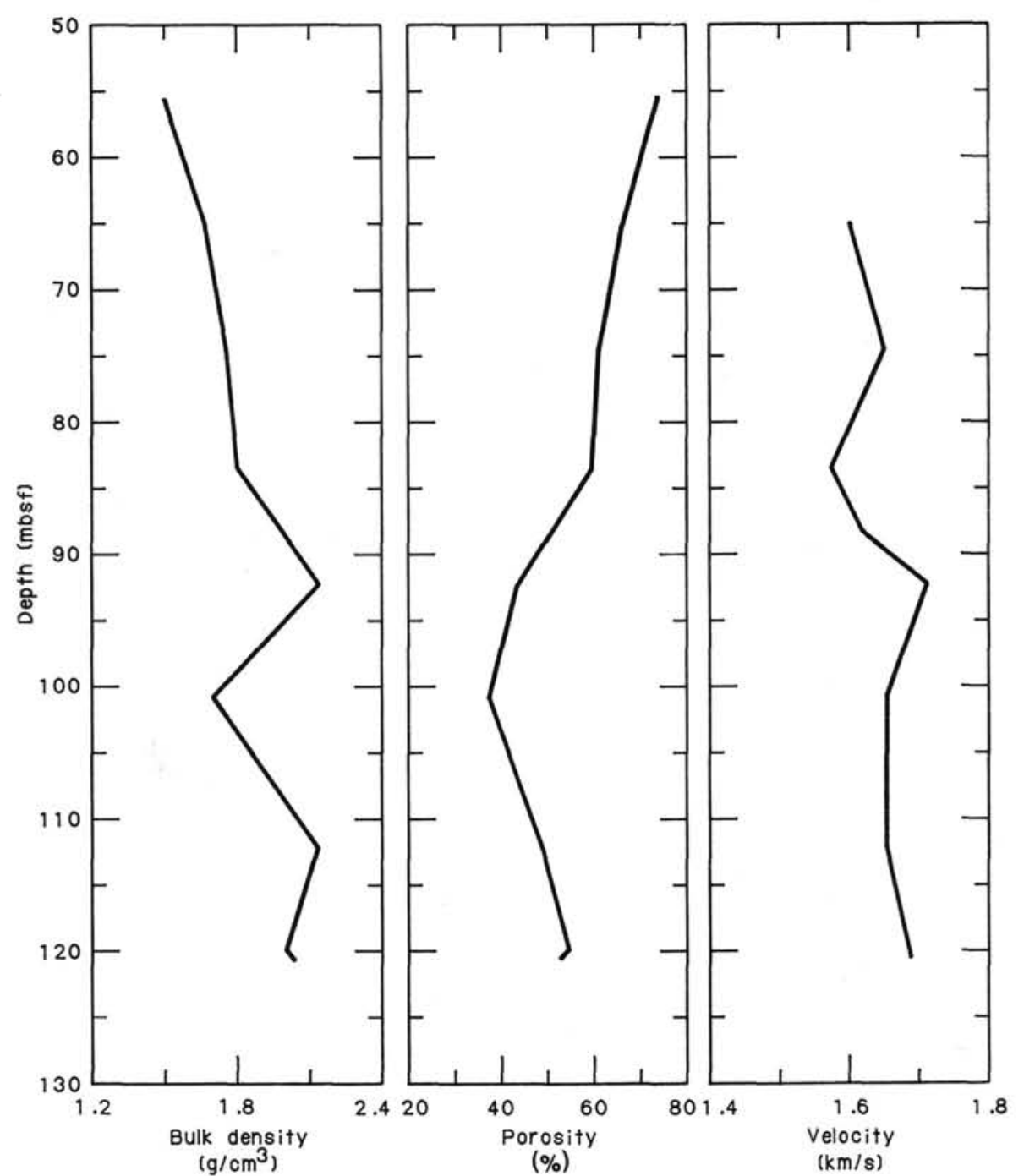

Figure 11. Bulk density, porosity, and velocity vs. depth at Hole 656B.

Unit I and II thicknesses between the two holes results from onlapping deposition on a sloping surface.

Unit III at Site 656A is a barren dolomitic mud. A Messinian age is inferred from the position of this unit beneath a normal (although condensed) Pliocene biostratigraphic succession. A similar lithology is encountered at Hole $656 \mathrm{~B}$, interbedded as a probable slump between lower Pliocene (NN12) and lower Pleistocene (NN19) sediments. The difference in stratigraphy between Holes 656A and 656B, with hiatuses in 656A and redeposited units in $656 \mathrm{~B}$, may be attributed to local basement relief.

Unit IV, in both Holes 656A and 656B, represents essentially a continental deposit such as an alluvial fan. The rock fragments of Unit IV are probably derived from the continental basement of Monte de Marchi. The nature of the clasts of this unit confirms the suggestion of previous workers (Colantoni et al., 1981; Gennesseaux et al., 1986) that Monte de Marchi contains a fragment of a complex Tethyan ophiolite alpine-type nappe as well as metamorphic complexes. The base of Hole 656A Unit IV may represent a true basement since the recovery in the last four cores was exclusively fragments of homogeneous basement rocks (stongly altered metagabbro).

\section{Tectonic Implications}

In light of the results from Sites 652,653 , and 654 , we had postulated that during the Messinian desiccation, the region that is now the lower Sardinian margin (Site 652) was higher standing than the region that is now the upper Sardinian margin (Sites 654 and 653). At Site 656, we recovered two distinct barren lithologies inferred to be Messinian: a dolomitic mud above a subaerial iron-rich coarse-clastic deposit. The presence of the subaerial deposit supports the hypothesis of a relief inversion between upper and lower margins since the Messinian. If the dolomitic mud is a marginal Messinian facies, its superposition above the subaerial clastics may be interpreted as a transgressive contact. Such a transgression could result from tectonic subsidence during the Messinian or from refilling of the Mediterranean at the end of the Messinian.

The presence of numerous hiatuses and confused stratigraphic successions attributed to slumps indicates significant sedimentary instability during the early Pliocene and early Pleistocene. Such mass movements indicate the existence of a relatively steep slope and/or tectonic activity during this time interval. This inference is compatible with drilling results at Site 652 , where the 


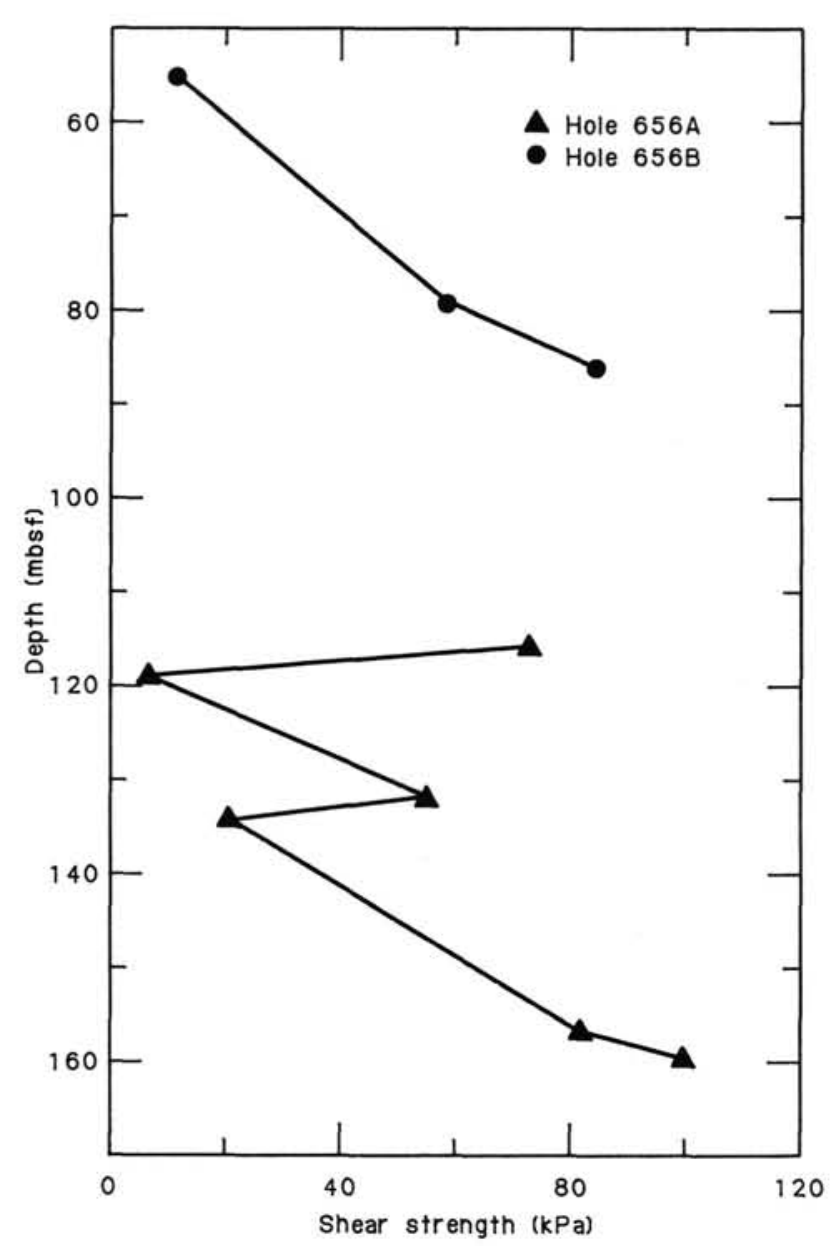

Figure 12. Shear strength vs. depth in Holes 656A and 656B.
Table 6. Shear strength measurements, Hole 656A.

\begin{tabular}{cccr}
\hline $\begin{array}{c}\text { Core } \\
\text { section }\end{array}$ & $\begin{array}{c}\text { Interval } \\
(\mathrm{cm})\end{array}$ & $\begin{array}{c}\text { Depth } \\
\text { sub-bottom } \\
(\mathrm{m})\end{array}$ & $\begin{array}{c}\text { Shear } \\
\text { strength } \\
(\mathrm{kPa})\end{array}$ \\
\hline $2 \mathrm{R}-3$ & 37 & 115.57 & 73.965 \\
$2 \mathrm{R}-5$ & 98 & 119.18 & 6.828 \\
$4 \mathrm{R}-1$ & 65 & 131.95 & 55.758 \\
$4 \mathrm{R}-3$ & 13 & 134.43 & 21.621 \\
$6 \mathrm{R}-5$ & 27 & 156.77 & 81.931 \\
$6 \mathrm{R}-7$ & 30 & 159.80 & 100.137 \\
\hline
\end{tabular}

Table 7. Shear strength measurements, Hole 656B.

\begin{tabular}{lccc}
\hline $\begin{array}{c}\text { Core } \\
\text { section }\end{array}$ & $\begin{array}{c}\text { Interval } \\
(\mathrm{cm})\end{array}$ & $\begin{array}{c}\text { Depth } \\
\text { sub-bottom } \\
(\mathrm{m})\end{array}$ & $\begin{array}{c}\text { Shear } \\
\text { strength } \\
(\mathrm{kPa})\end{array}$ \\
\hline 1R-1 & 32 & 55.42 & 11.379 \\
3R-6 & 137 & 83.67 & 59.172 \\
4R-6 & 52 & 91.92 & 85.344 \\
\hline
\end{tabular}

syn-rift sequence was Messinian to early Pliocene in age, and with the observation of active faulting on the lower Sardinian margin.

\section{REFERENCES}

Colantoni, P., Fabbri, A., Gallignani, P., Sartori, R., and Rehault, J.-P., 1981. Lithologic and stratigraphic map of the Italian Seas. Consiglio Naz. Ricerche, Publ. 4.

Gennesseaux, M., Rehault, J.-P., Thomas, B., Colantoni, P., Fabbri, A., Lepvrier, C., Mascle, G., Mauffret, A., Polino, R., Robin, C., and Vanney, J., 1986. Les blocs bascules de la mer Tyrrhenian centrale et le volcan sous-marin Vavilov: resultats des plongees en submersible Cyana. C. R. Acad. Sci. Ser. A, 12:705-792. 
SITE 656 HOLE A CORE 1 R

CORED INTERVAL $3699.8-3709.2 \mathrm{mbsl} ; 102.8-112.2 \mathrm{mbsf}$

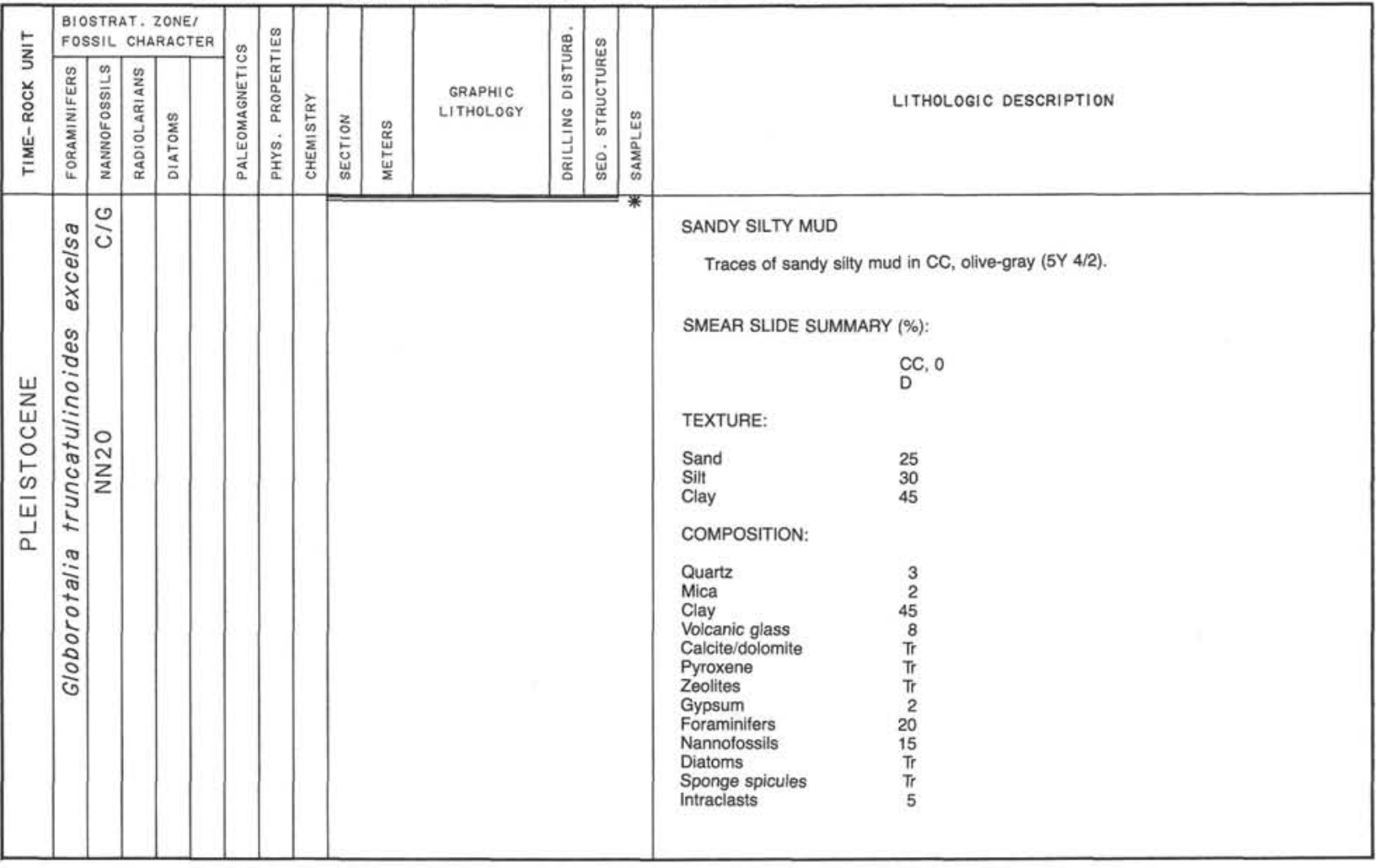


SITE 656 HOLE A CORE $2 \mathrm{R}$ CORED INTERVAL $3709.2-3718.7 \mathrm{mbs} \mid ; 112.2-121.7 \mathrm{mbsf}$

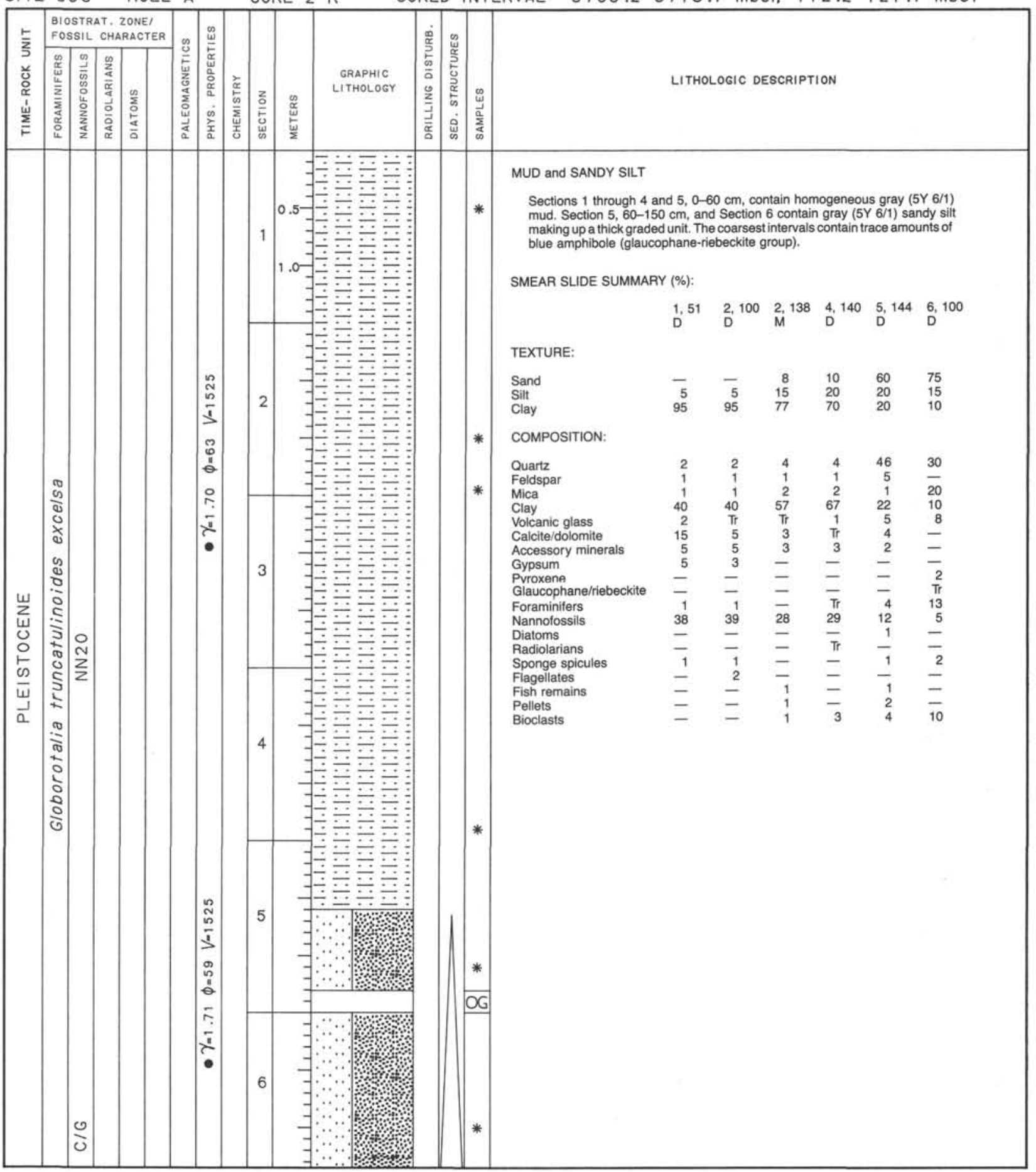




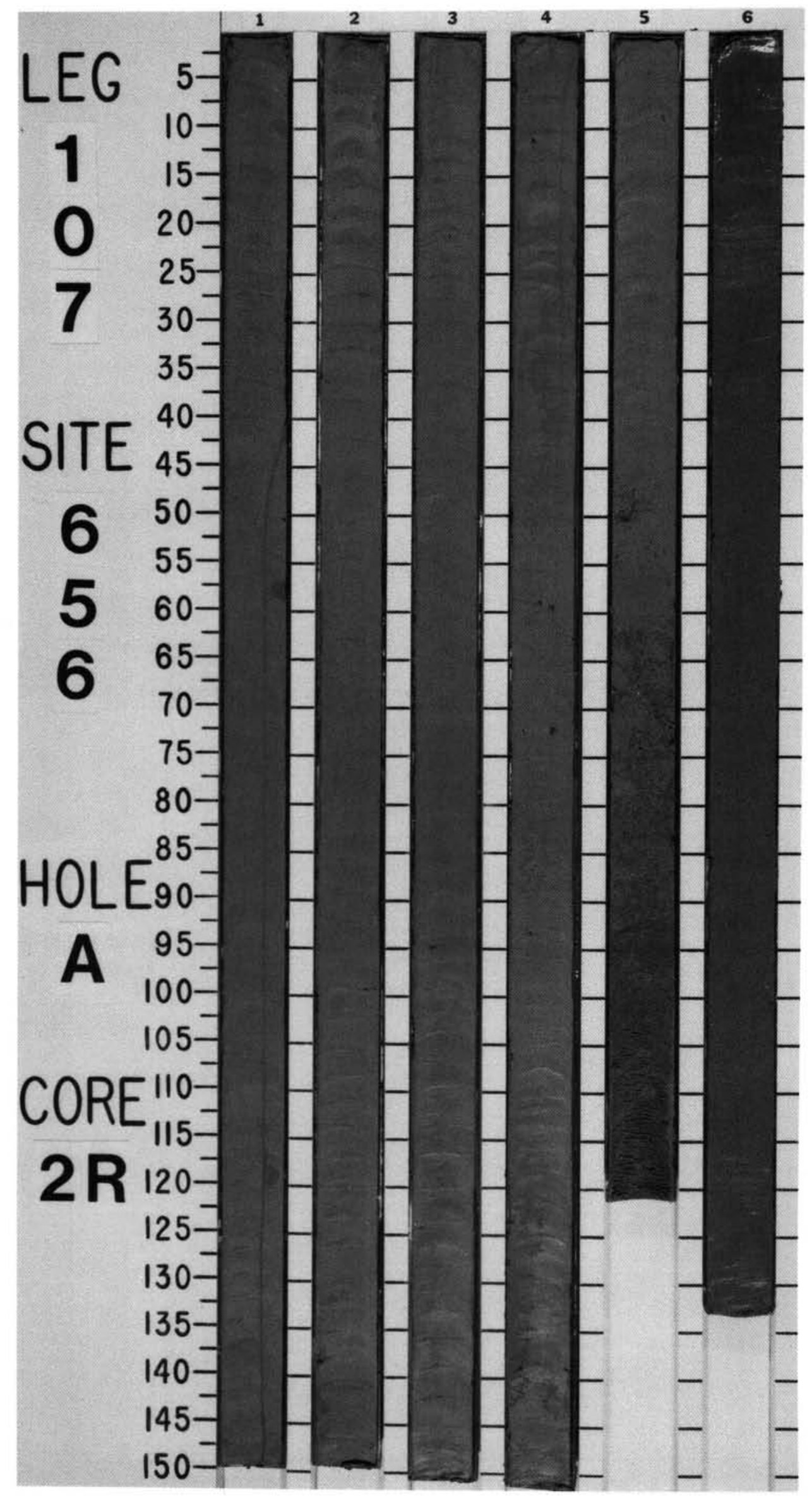




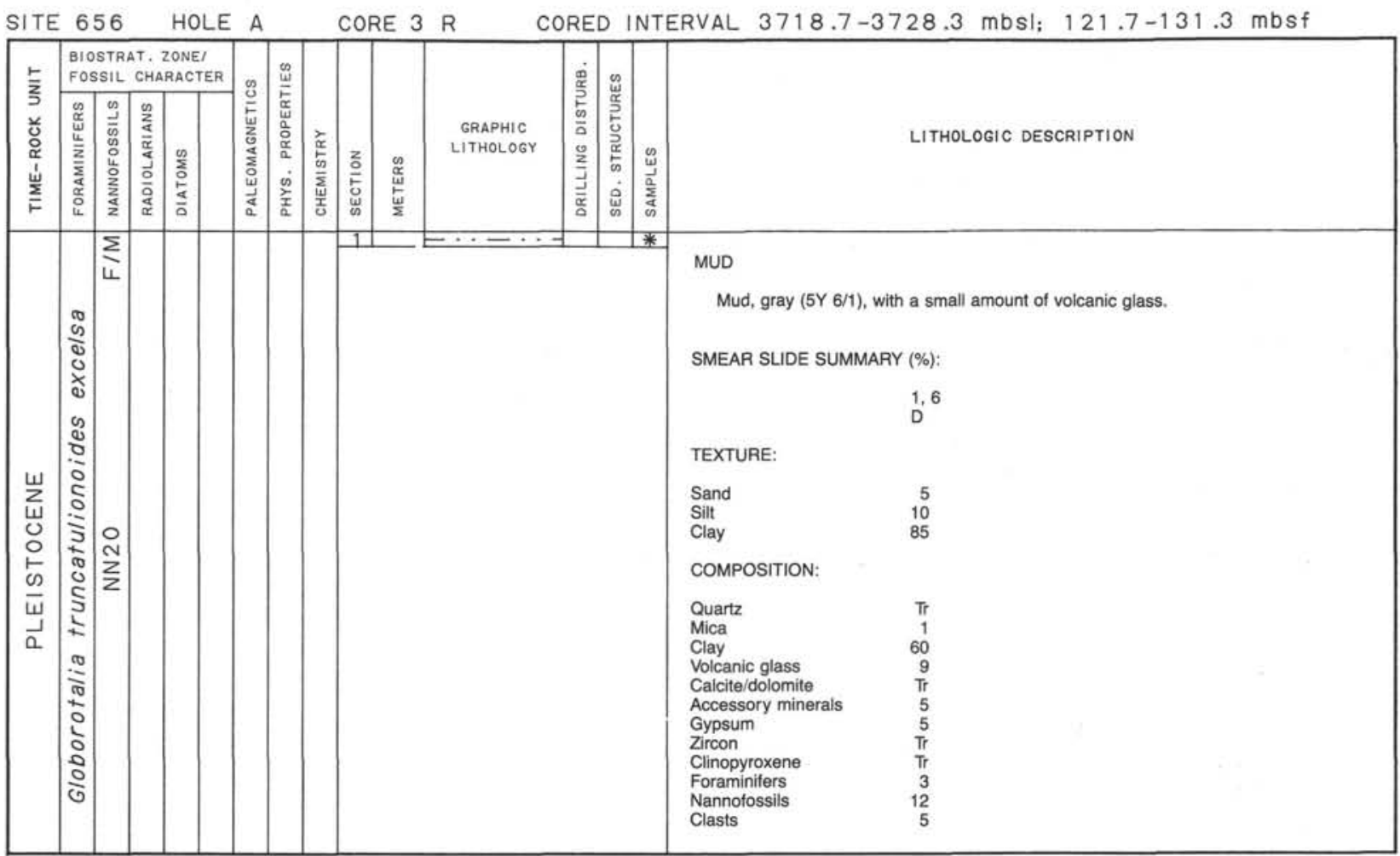

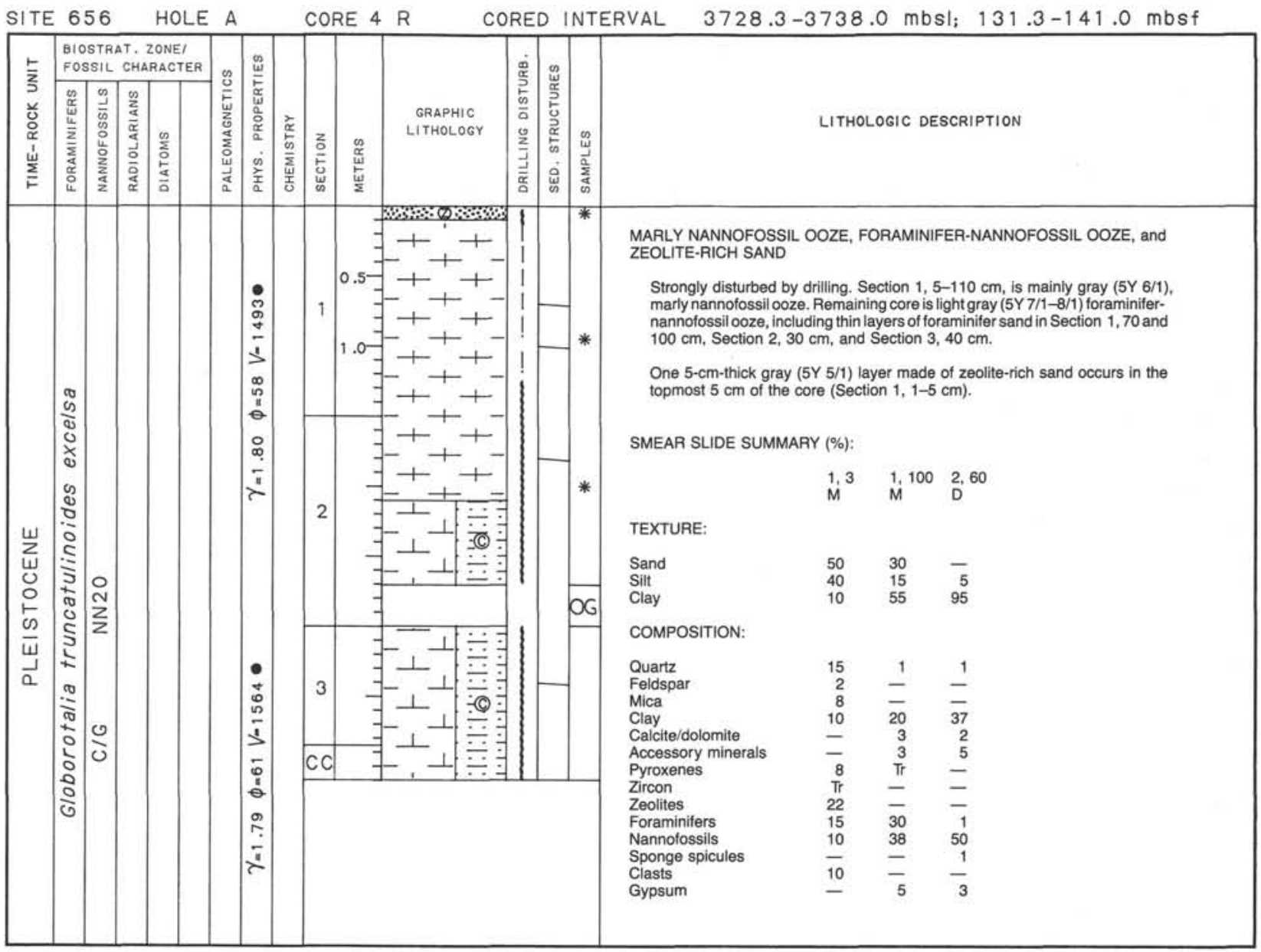




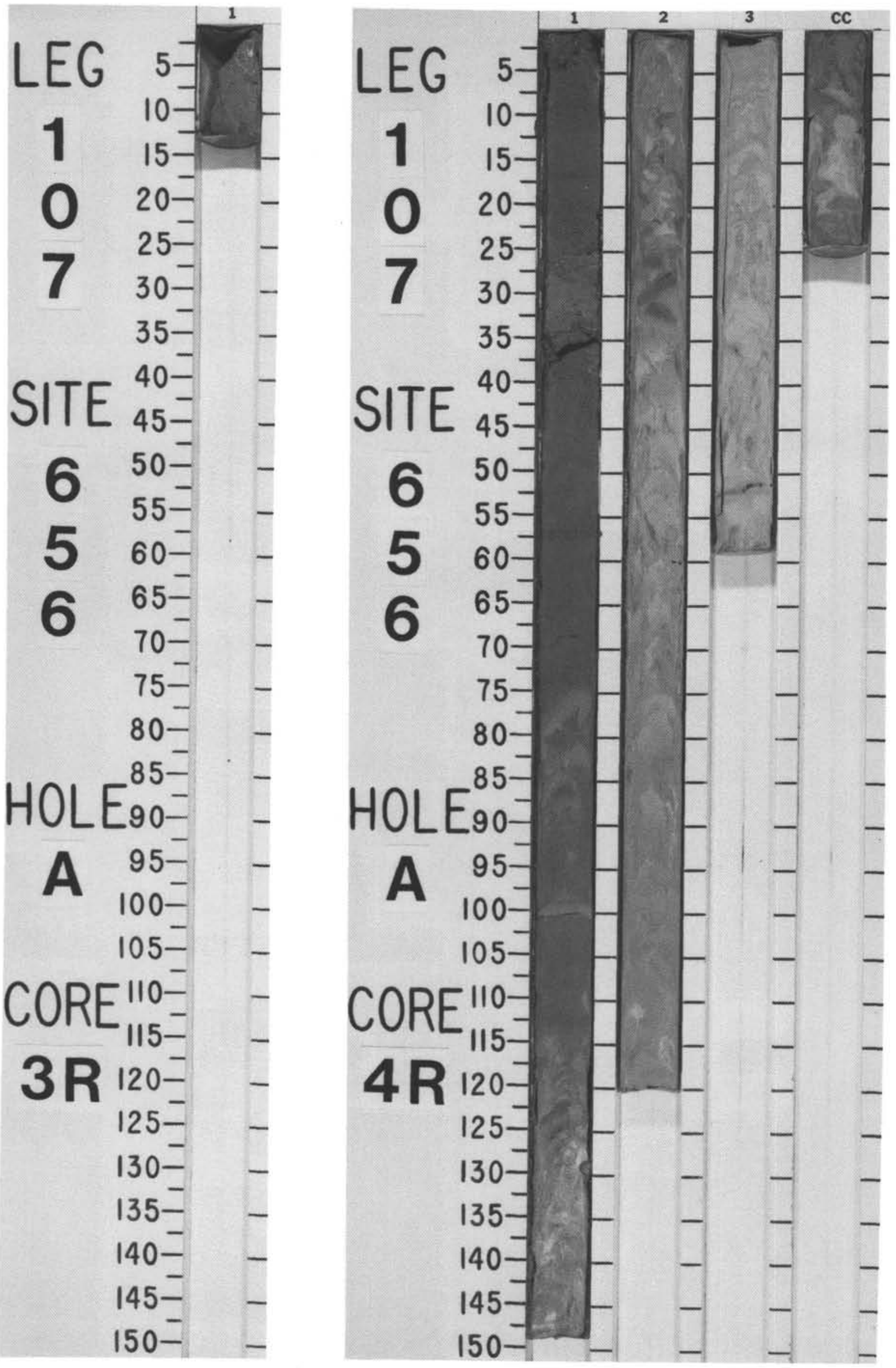




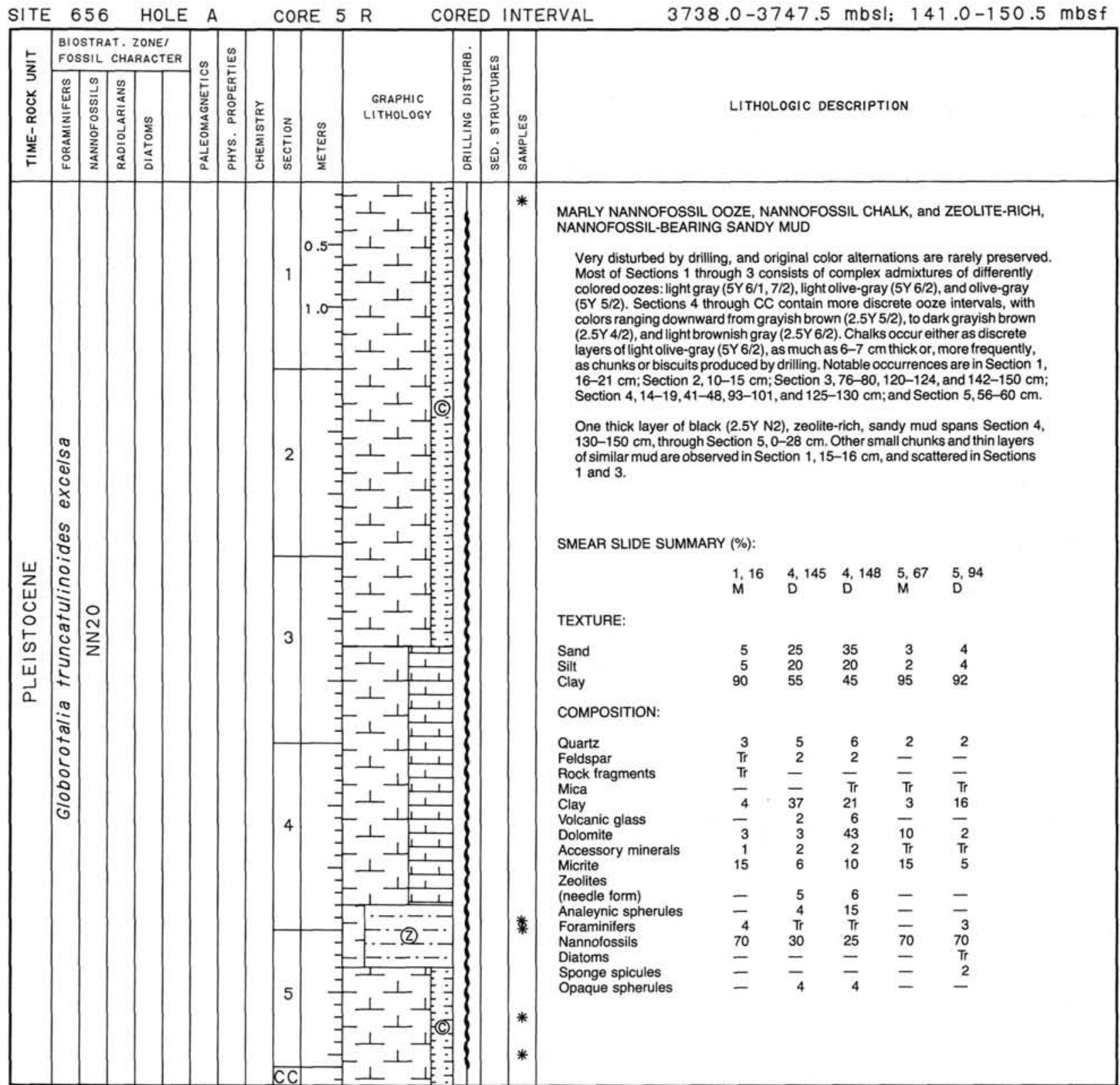




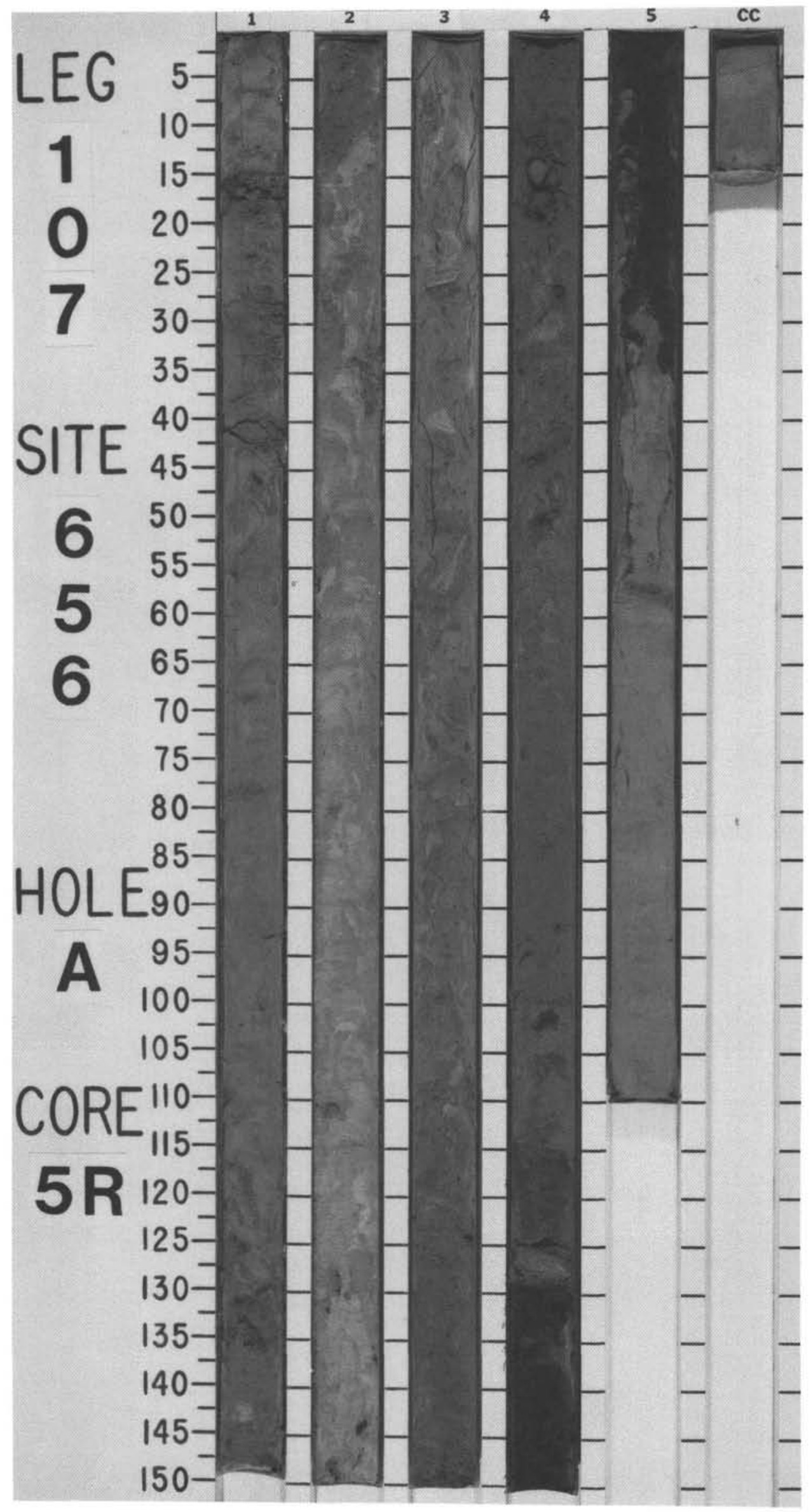




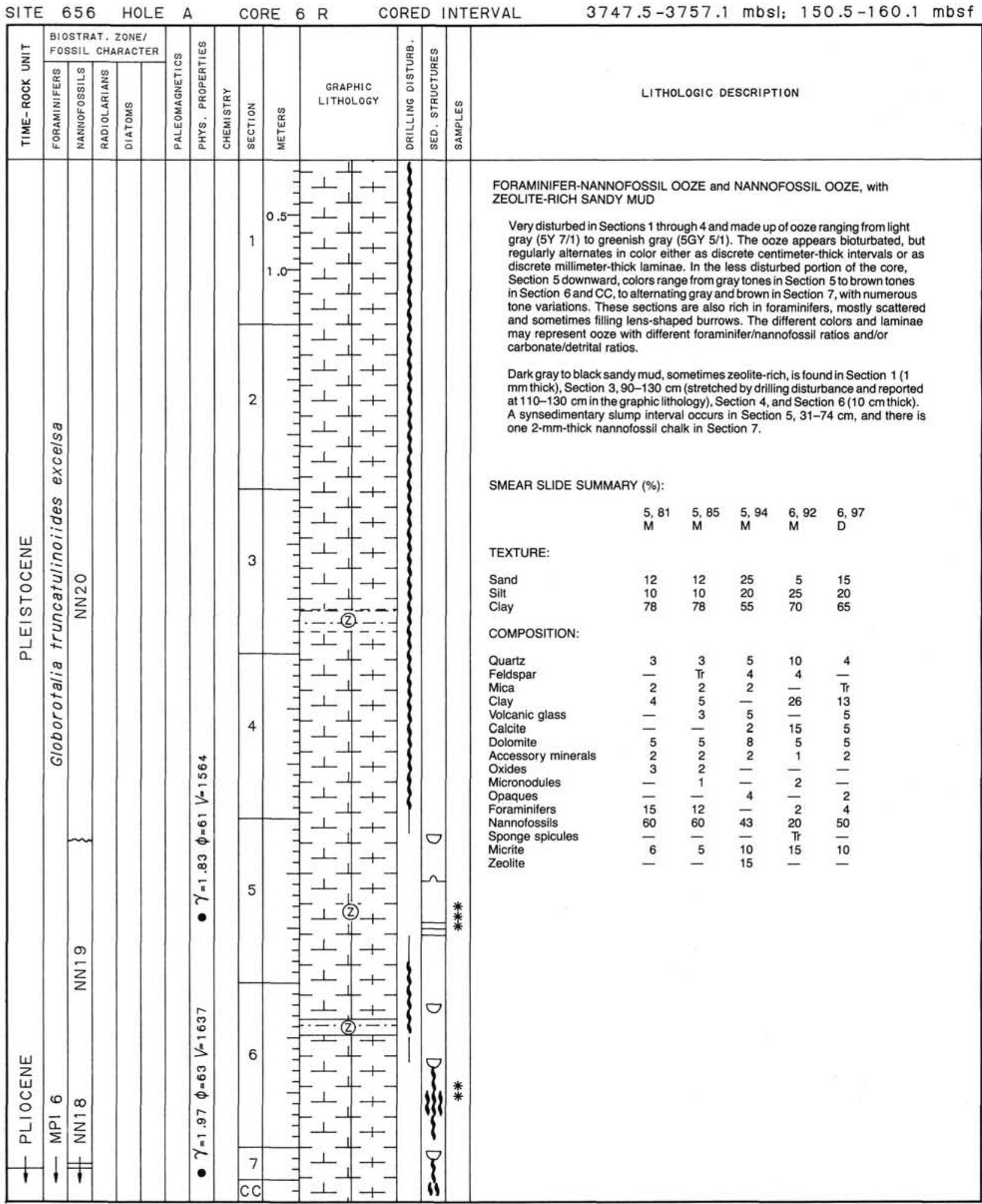




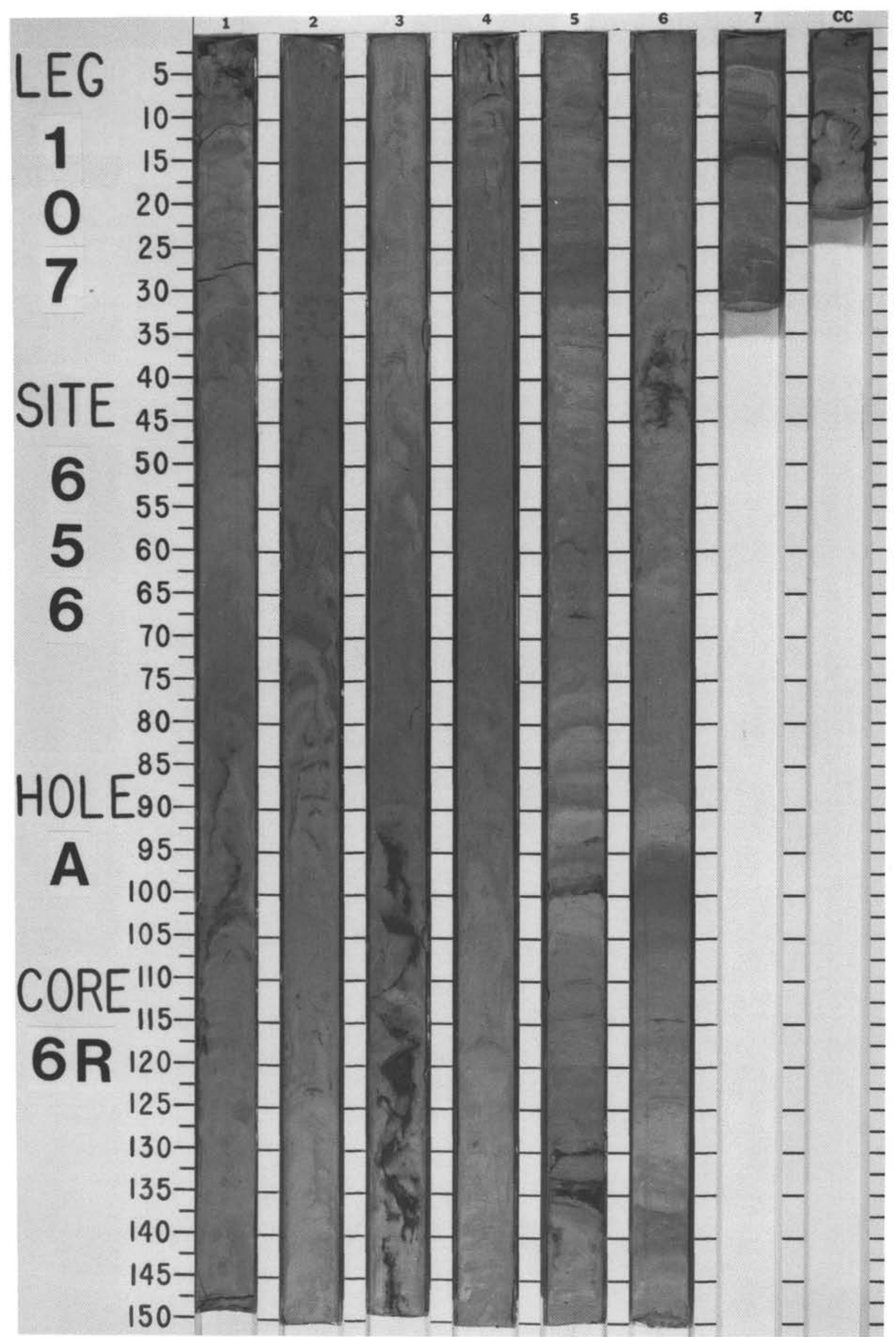




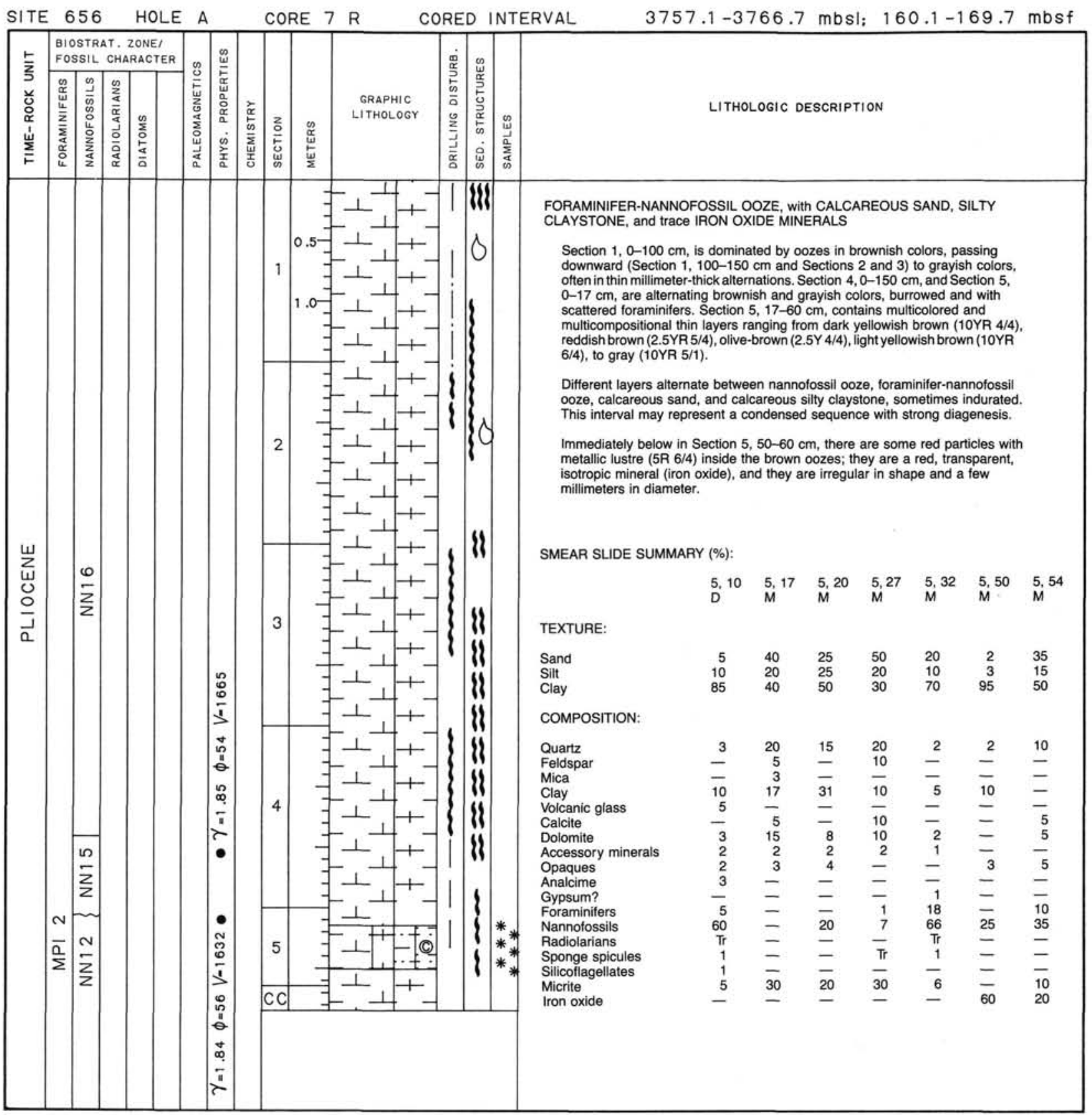




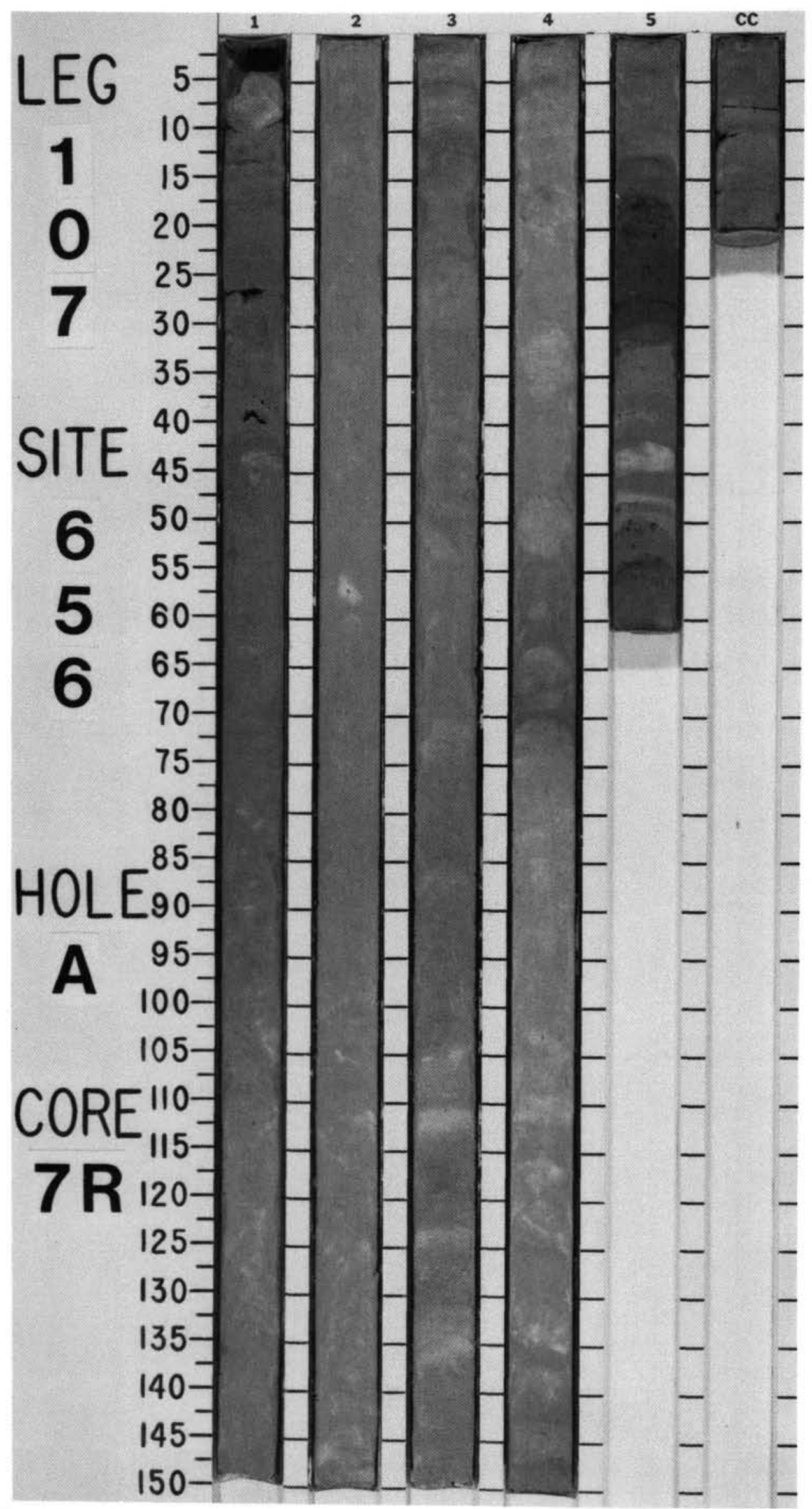


SITE 656

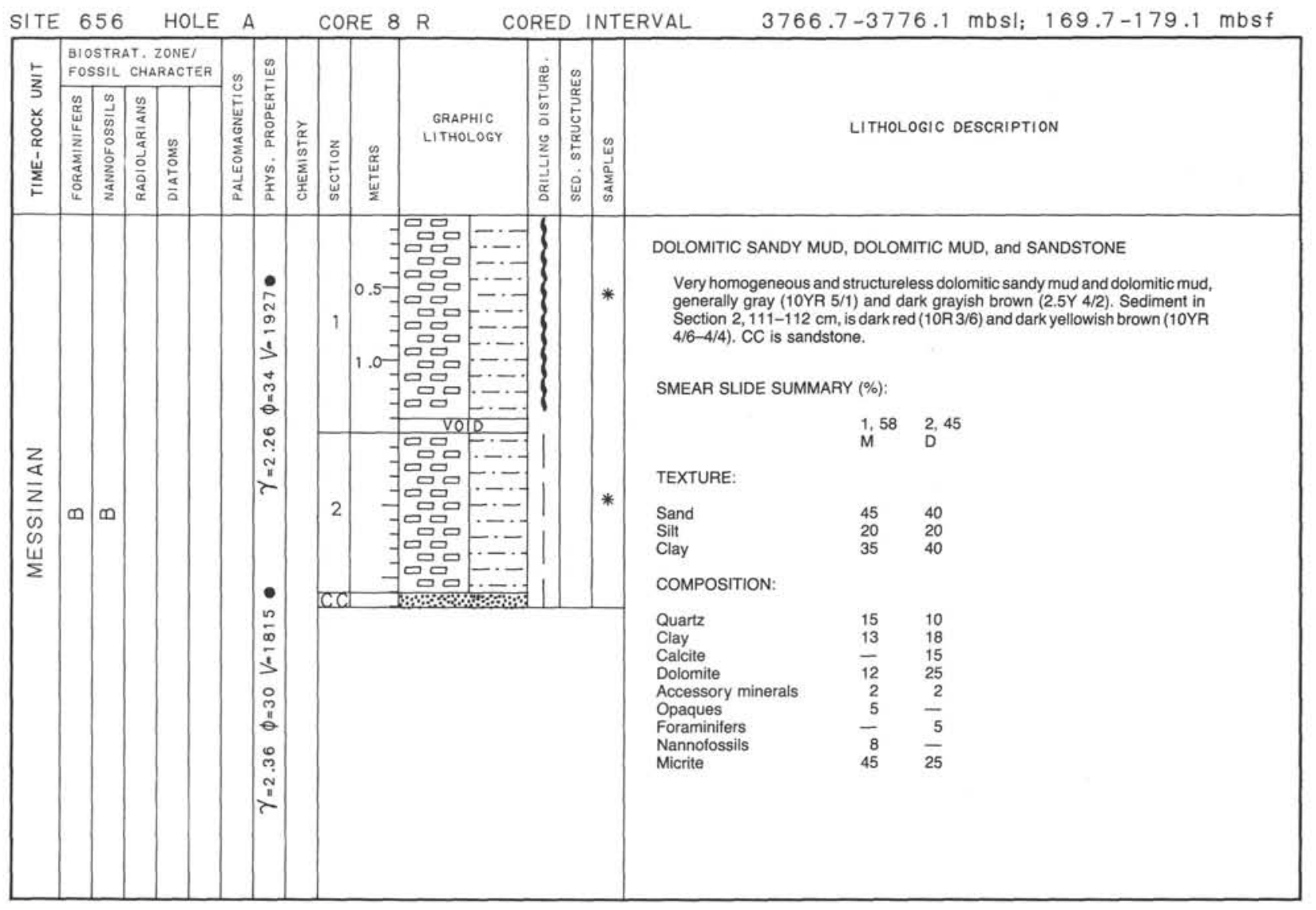

978 


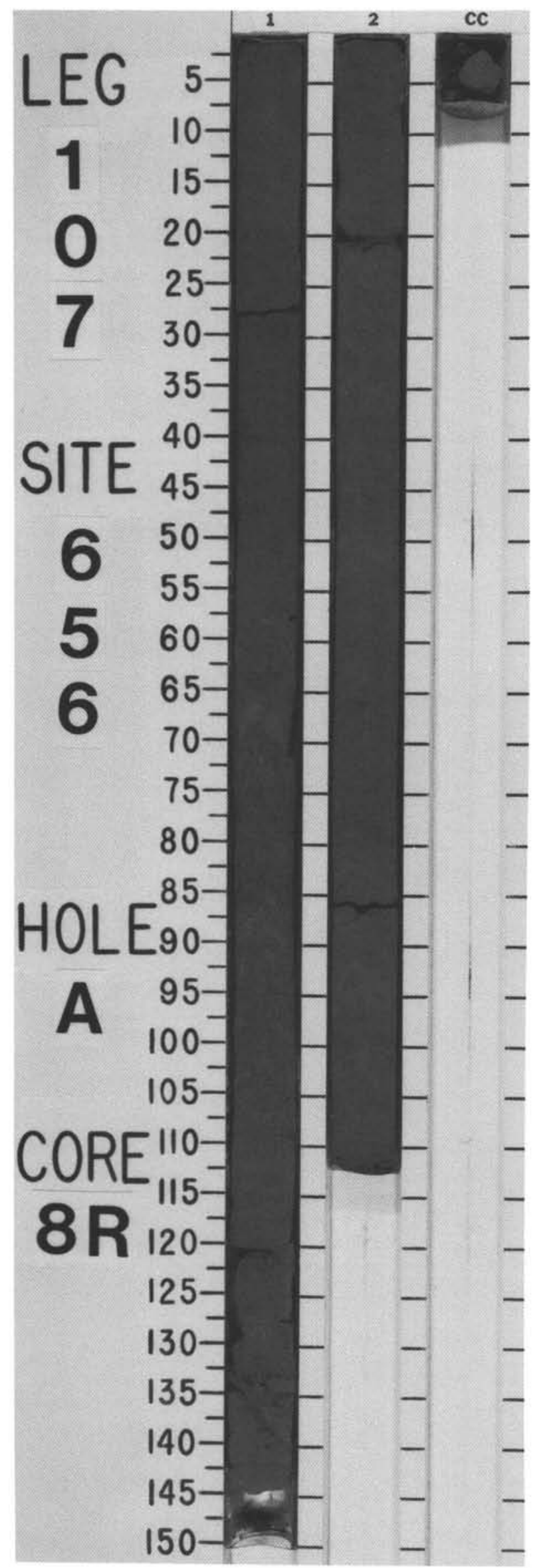


SITE 656 HOLE A CORE 9 R

CORED INTERVAL

$3776.1-3785.2 \mathrm{mbsl}: 179.1-188.2 \mathrm{mbsf}$

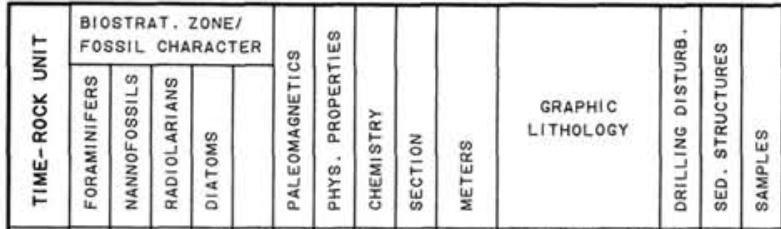

LITHOLOGIC DESCRIPTION

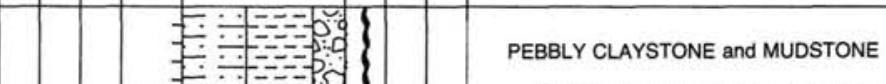

Mostly brick-red mudstone and claystone with scattered pebbles of the following lithologies:

\#1: greenish siltstone and fine-grained sandstone

\#2: reddish dolomitic mar

\#3: altered greenstone

\#4: red chert

\#5: silicified micritic limestone

\#6: limonitic clay

\#7: crystalline sulfur (pyrite, chalcopyrite, and galena)

\#8: amphibole-rich rock

\#9: mudstone

Section 1 is plastic, reddish claystone with numerous mud clasts and pebbles of sandstone and siltstone. Section 2 is same but weak red, and Section 3 is dark red, with rock fragments (sandstone) as large as $4 \times 3 \times 3 \mathrm{~cm}$. Section 4

consists of a more silty, weak red matrix with pebbles of sandstone and chert.

Section 5 is composed of dark gray (reduced) clasts of sandstone, chert, and metagabbro. Section 6 is a conglomerate of reddish gray dolomitic clay and gray clay matrix with pebbles of sandstone, chert, dolomite, and greenstone. gray clay matrix with pebbles of sandstone, chert, dolomite, and greenstone metagabbro. Sections 6 and 7 are highly disturbed by drilling. CC is same as

- E.:- $\quad$ metagabbro.

SMEAR SLIDE SUMMARY (\%):

3

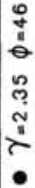

4

6

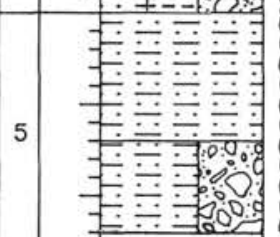

$-$

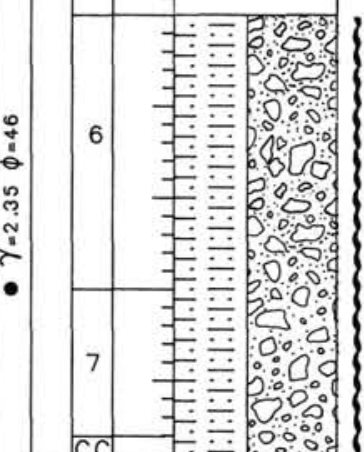

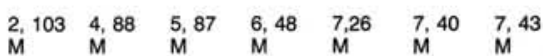

TEXTURE:

Sand

Silt

Clay

$\begin{array}{rrrrlll}5 & 35 & 50 & \overline{1} & \overline{1} & \overline{20} & \overline{20} \\ 5 & 25 & 20 & 40 & = & 80 & 80\end{array}$

COMPOSITION:

Quartz

Feldspar
Rock fragments

* Mock

Clay

Calcite
Dolomite

Accessory minerals

Limonite(?)

Opaques

Micrite

Bauxiticmineral(?)

Rutile

*

Zeolites

\begin{tabular}{|c|c|c|c|c|}
\hline 25 & 5 & - & $\mathrm{Tr}$ & $\mathrm{Tr}$ \\
\hline$=$ & 2 & - & - & - \\
\hline 5 & & \pm & $\bar{z}$ & - \\
\hline 20 & 19 & - & - & 60 \\
\hline $\begin{array}{l}25 \\
20\end{array}$ & $\begin{array}{l}40 \\
20\end{array}$ & $\overline{\mathrm{Tr}}$ & $\bar{z}$ & $\overline{10}$ \\
\hline 2 & 1 & $\overline{100}$ & $\overline{3}$ & $\overline{15}$ \\
\hline 3 & 3 & - & - & 15 \\
\hline- & 10 & $\bar{T}$ & - & - \\
\hline- & $\bar{z}$ & - & 65 & - \\
\hline$z$ & - & $z$ & $=$ & Tr \\
\hline
\end{tabular}




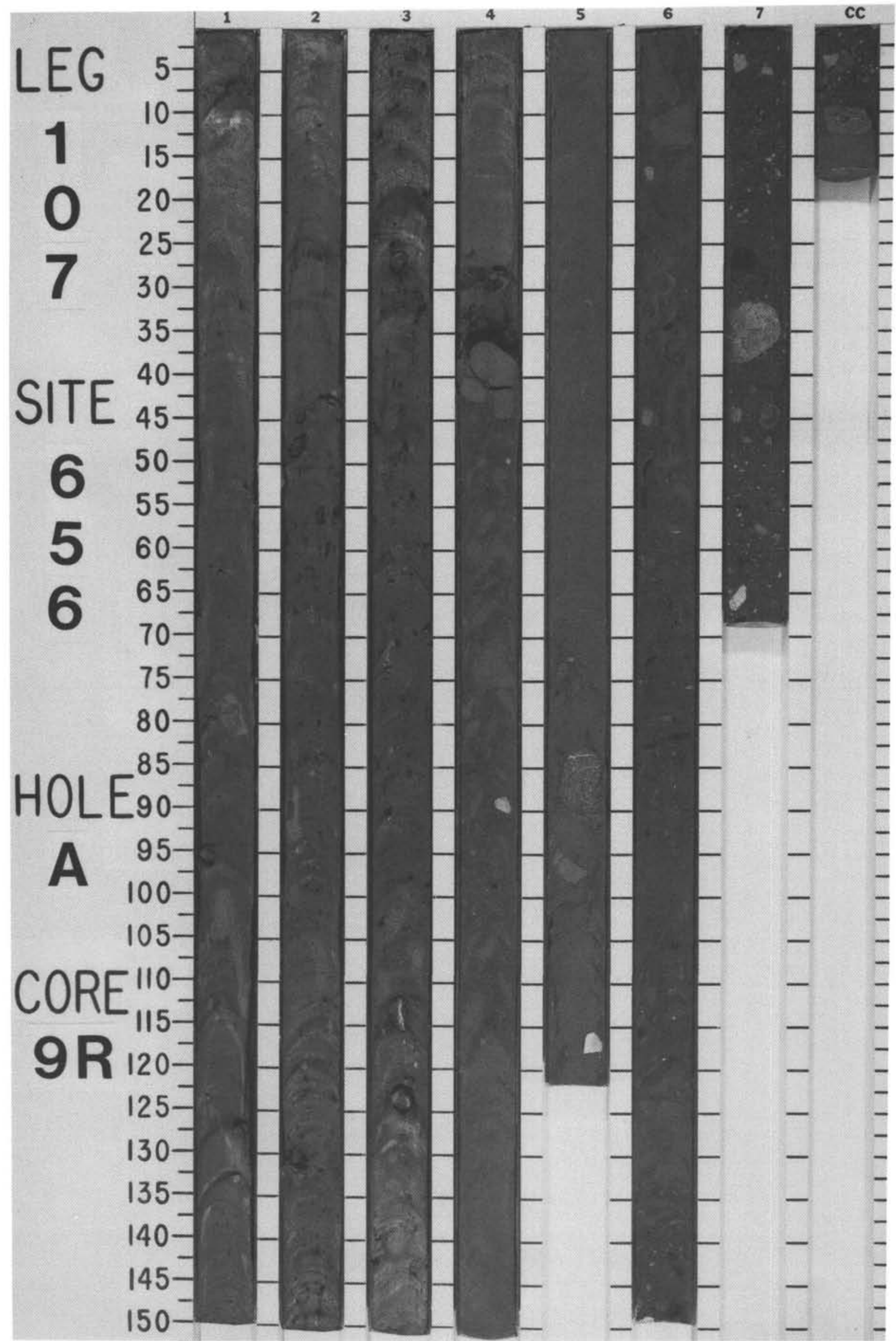




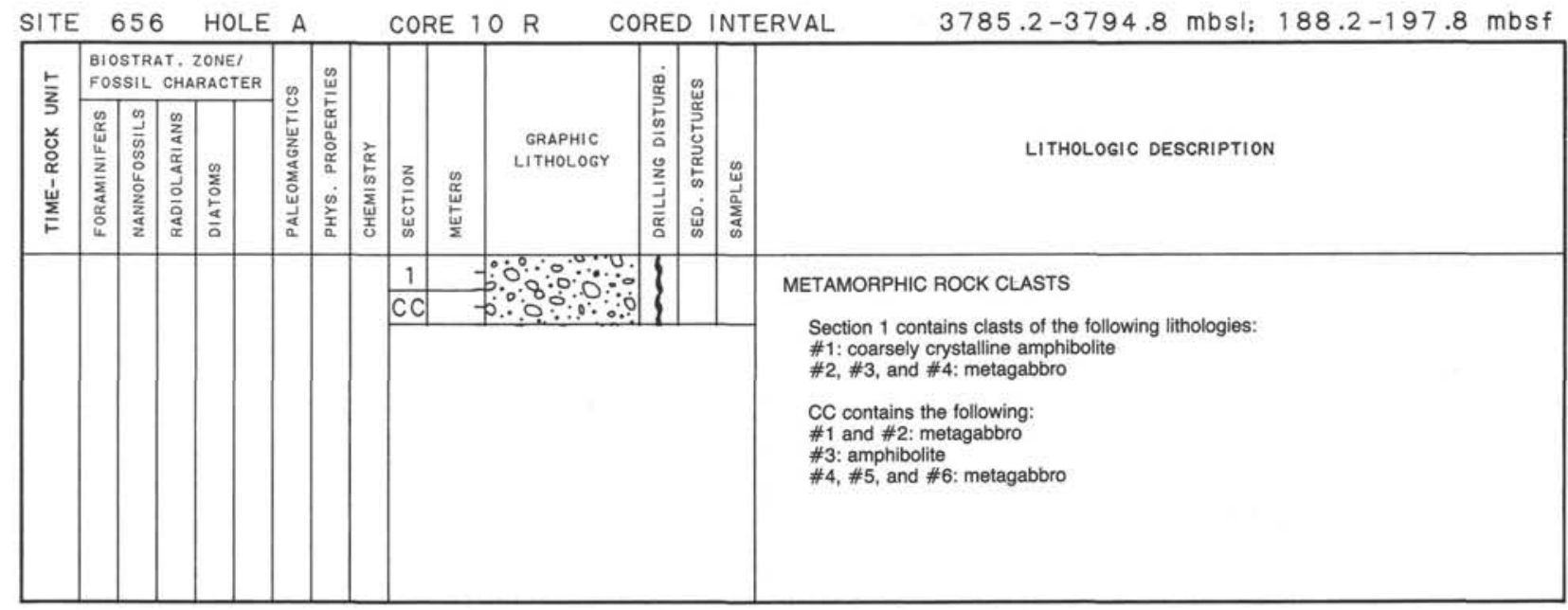

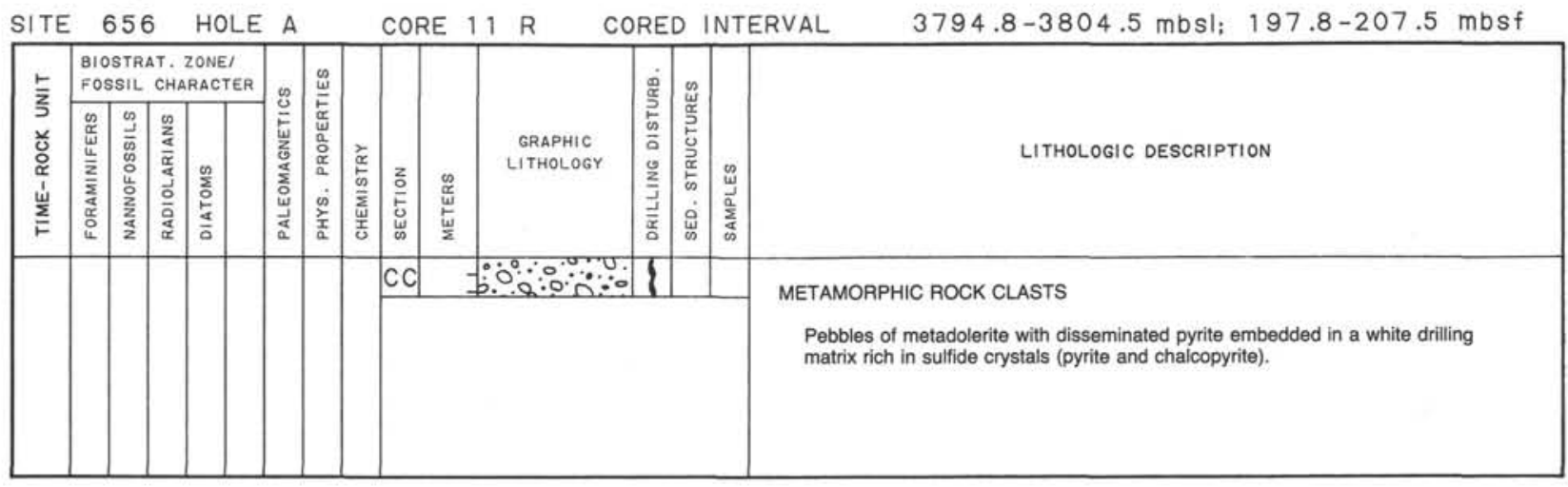




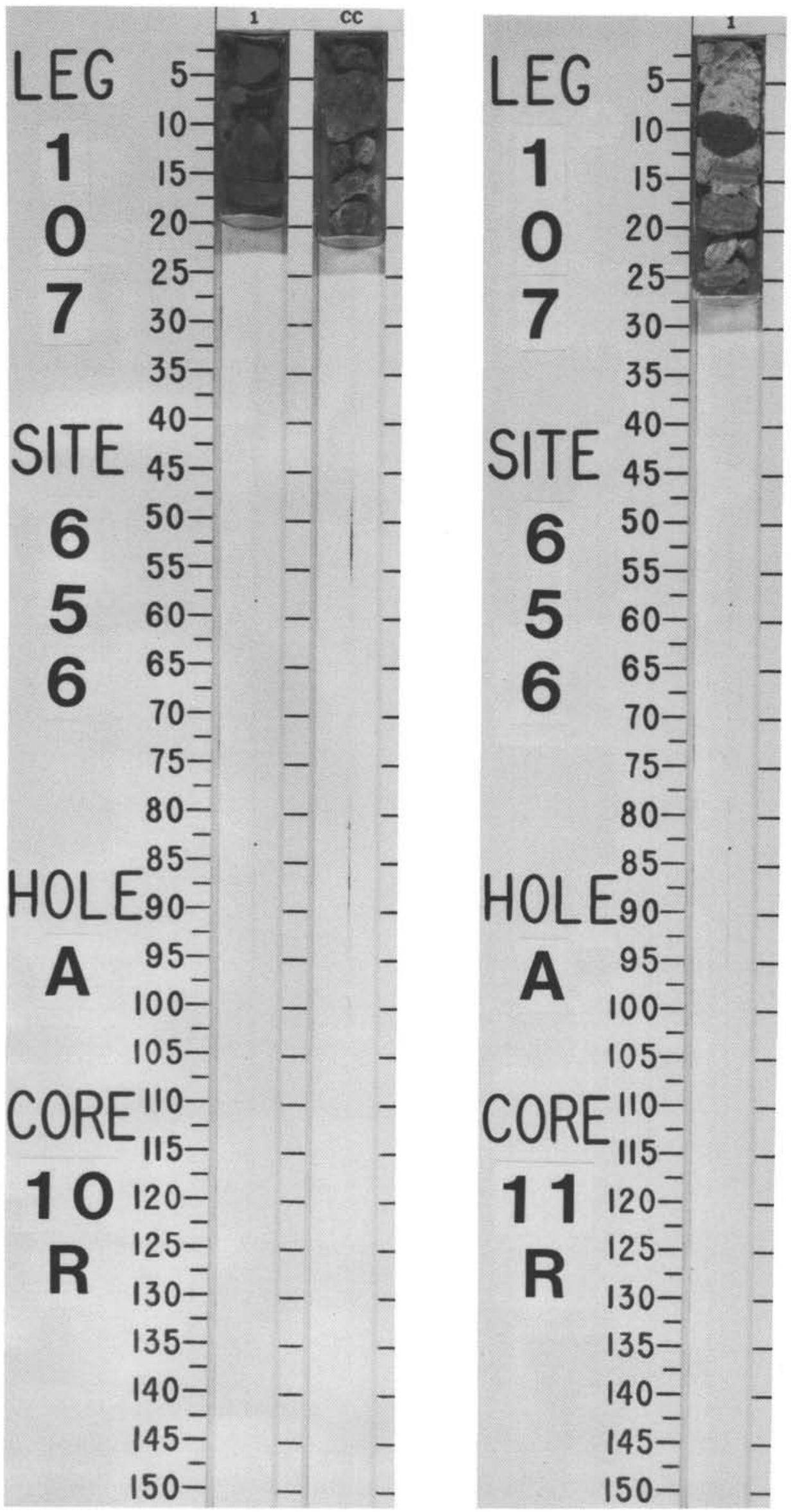


SITE 656 HOLE A CORE $12 \mathrm{R}$ CORED INTERVAL $3804.5-3814.2 \mathrm{mbsl}: 207.5-217.2 \mathrm{mbsf}$

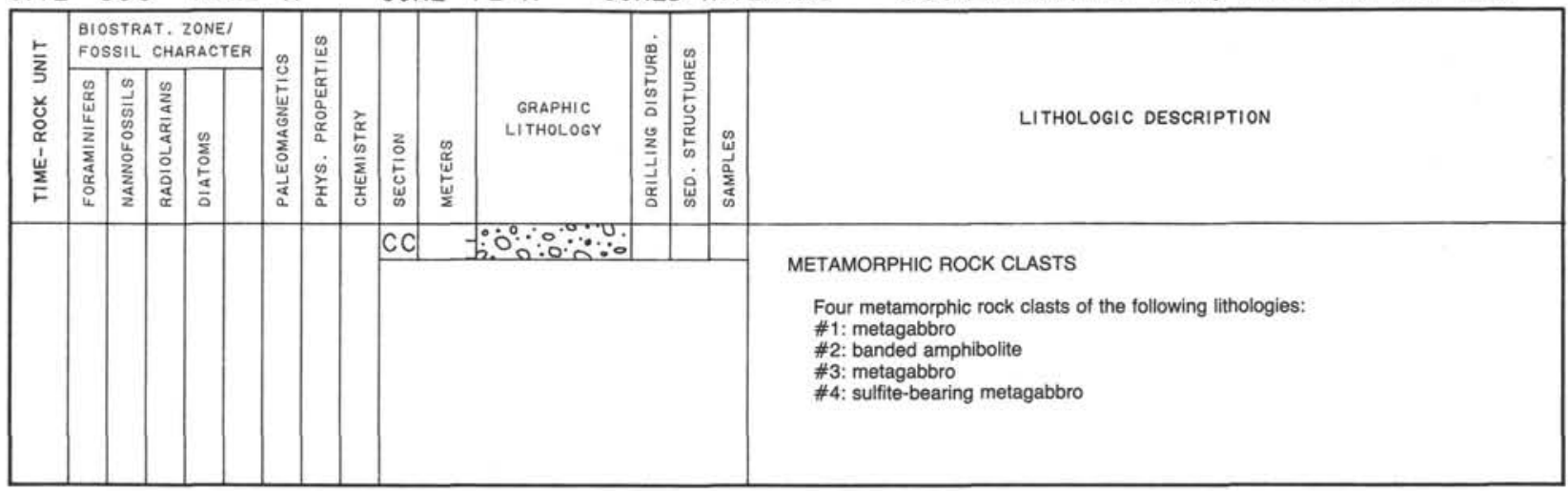

SITE 656 HOLE A CORE $13 \mathrm{R}$ CORED INTERVAL 3814.2-3823.8 mbsI; $217.2-226.8 \mathrm{mbS} f$

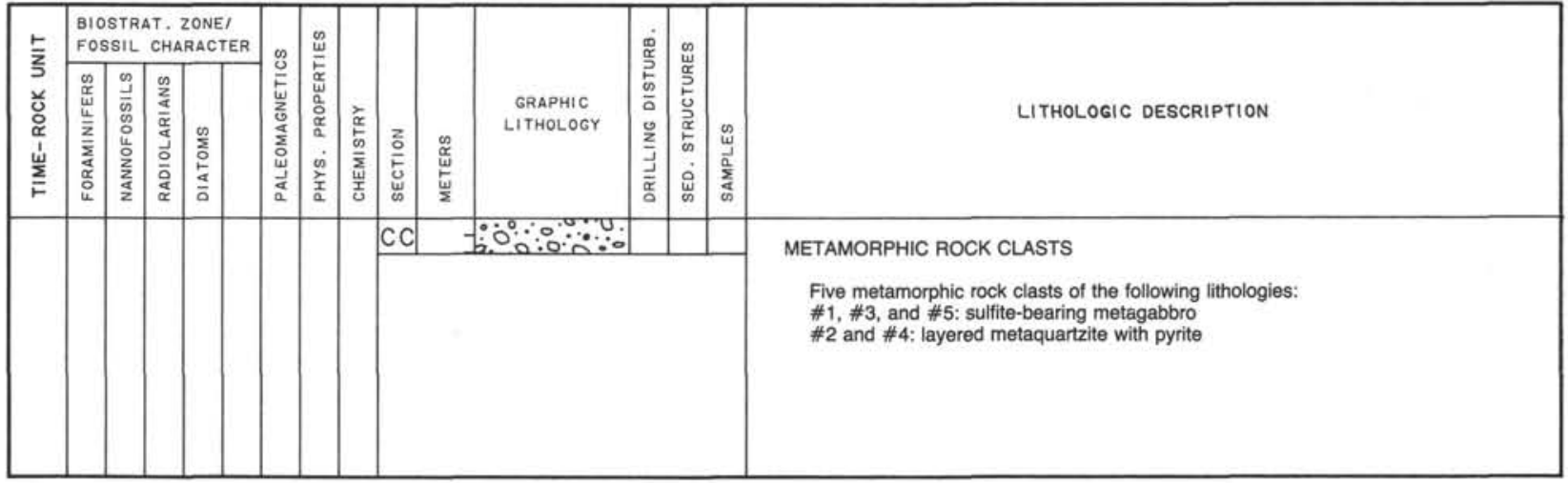

SITE 656 HOLE A CORE $14 \mathrm{R}$ CORED INTERVAL $3823.8-3833.4 \mathrm{mbsl;} 226.8-236.4 \mathrm{mbSf}$

\begin{tabular}{|c|c|c|c|c|c|c|c|c|c|c|c|c|c|}
\hline \multirow[b]{2}{*}{ 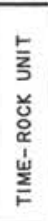 } & \multicolumn{4}{|c|}{$\begin{array}{l}\text { BIOSTRAT, ZONEI } \\
\text { FOSSIL CHARACTER }\end{array}$} & \multirow[b]{2}{*}{ 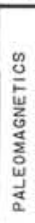 } & \multirow[b]{2}{*}{ 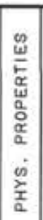 } & \multirow[b]{2}{*}{ 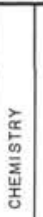 } & \multirow[b]{2}{*}{ 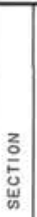 } & \multirow[b]{2}{*}{ 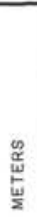 } & \multirow[b]{2}{*}{$\begin{array}{l}\text { GRAPHIC } \\
\text { LITHOLOGY }\end{array}$} & \multirow[b]{2}{*}{ 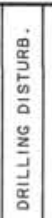 } & \multirow[b]{2}{*}{ 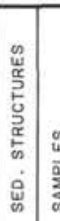 } & \multirow[b]{2}{*}{ LITHOLOGIC DESCRIPTION } \\
\hline & 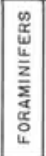 & 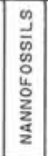 & 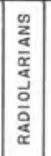 & 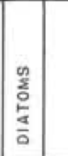 & & & & & & & & & \\
\hline & & & & & & & & & & 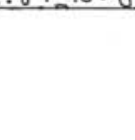 & & & $\begin{array}{l}\text { METAMORPHIC ROCK CLASTS } \\
\text { Two metamophic rock clasts of the following lithologies } \\
\text { \#1: calcareous amphibolite } \\
\text { \#2: chlorite-bearing metagabbro with minor sulfite }\end{array}$ \\
\hline
\end{tabular}




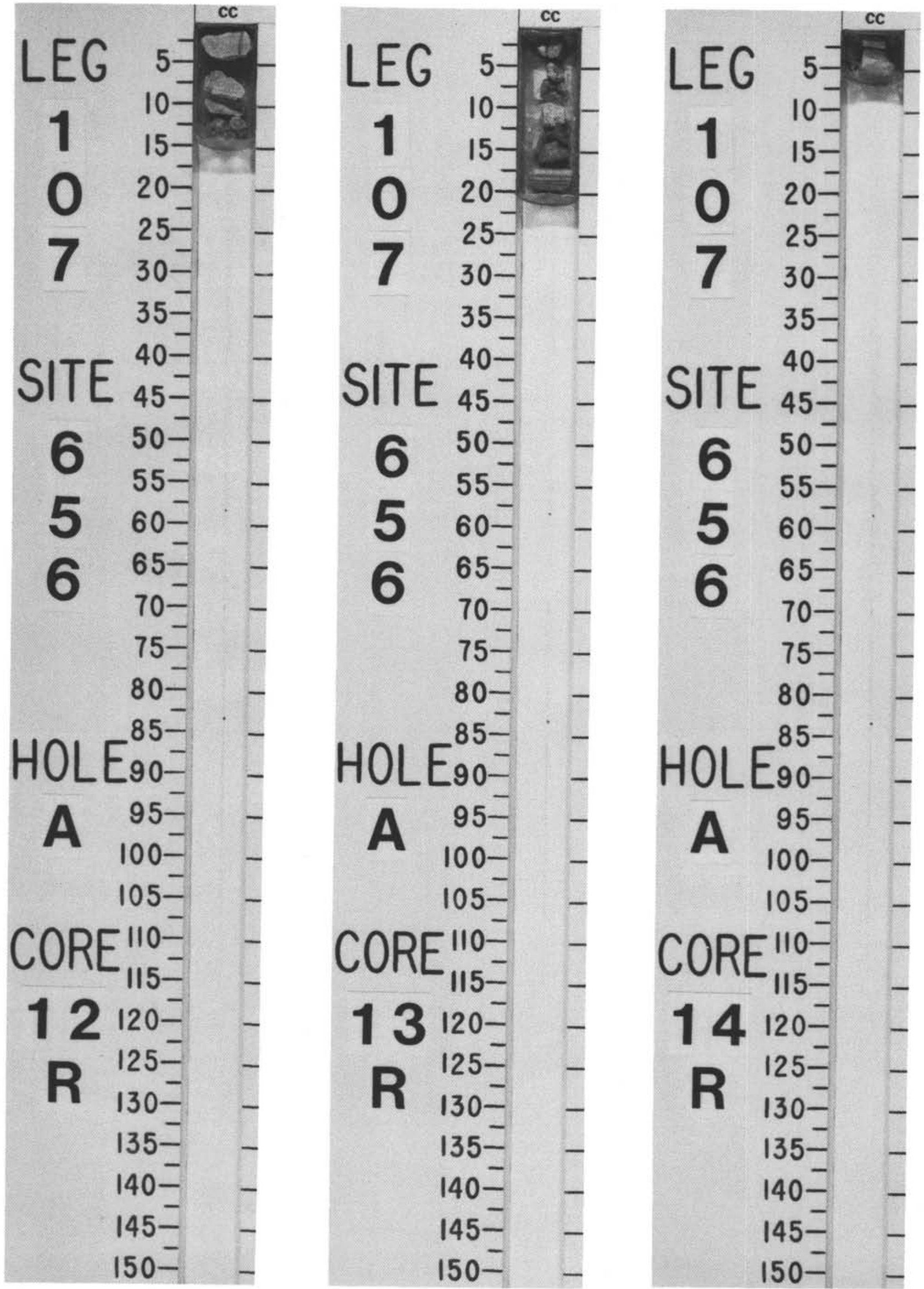


SITE 656 HOLE B CORE $1 \mathrm{R}$ CORED INTERVAL $3652.5-3662.1 \mathrm{mbsl} ; \quad 55.5-65.1 \mathrm{mbSf}$

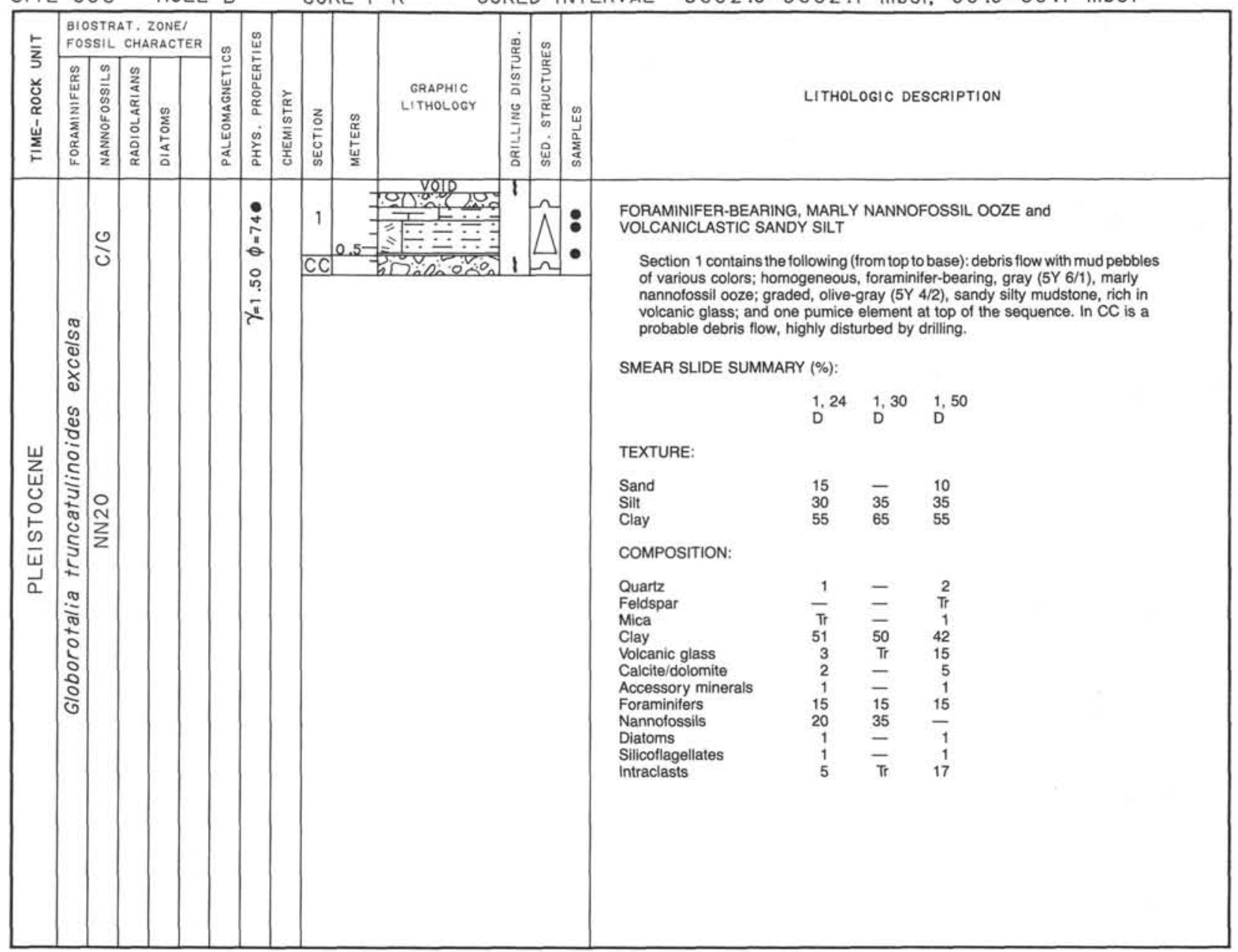




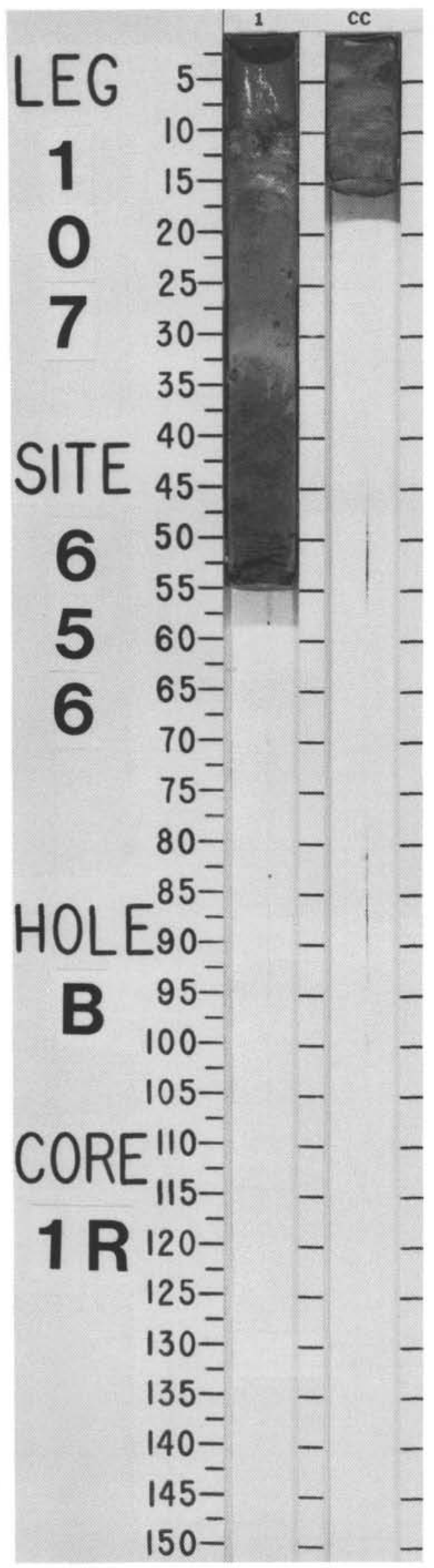




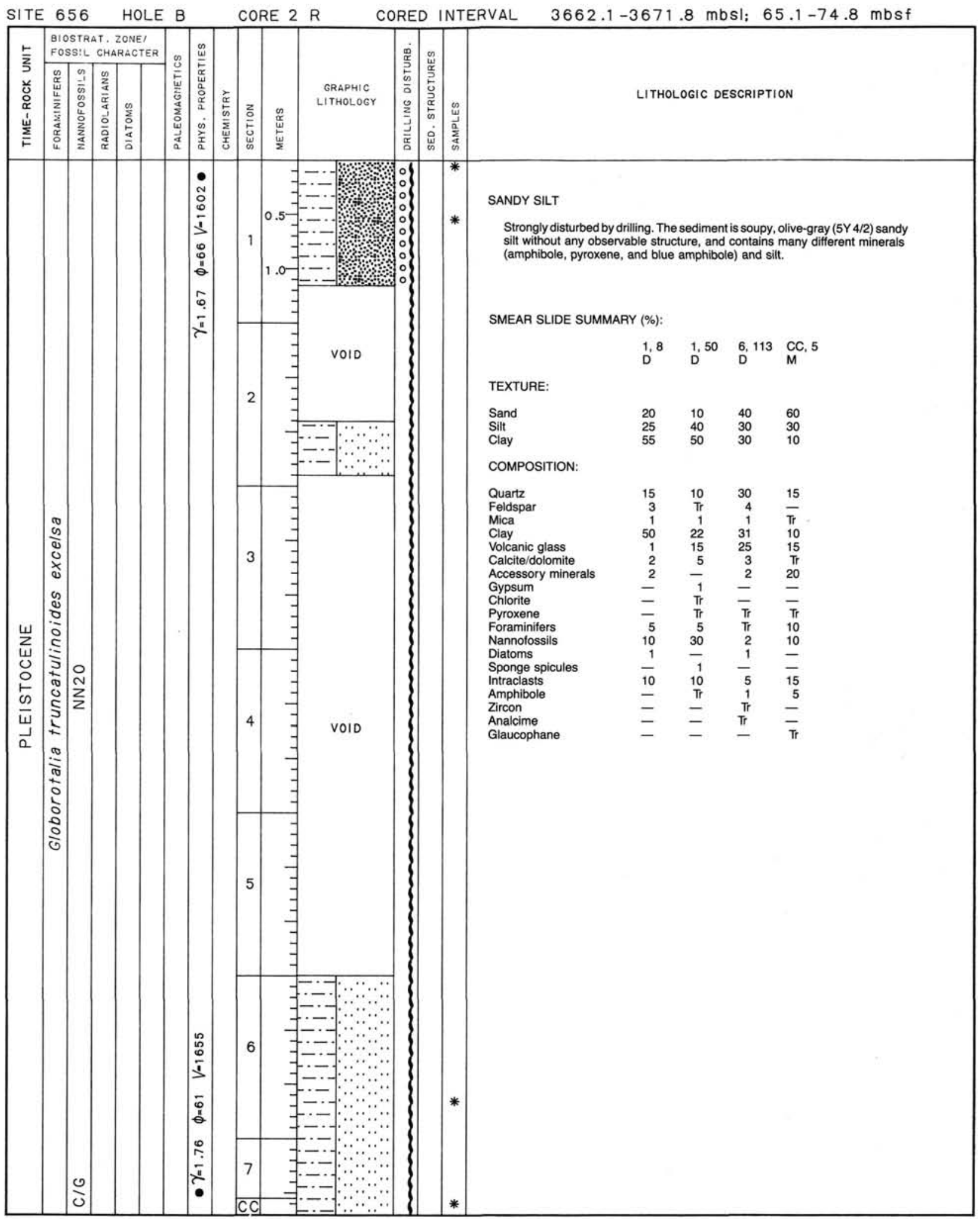




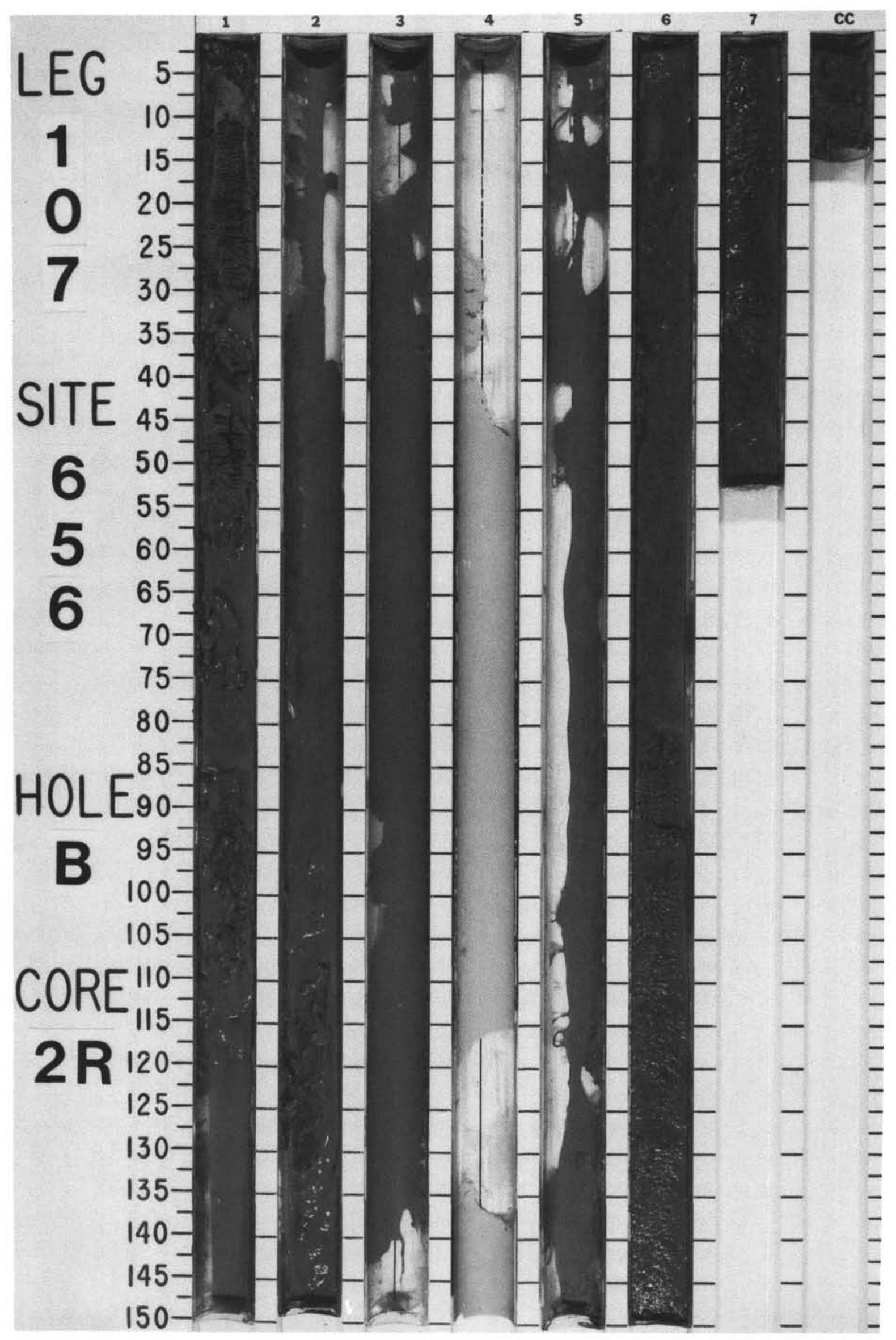




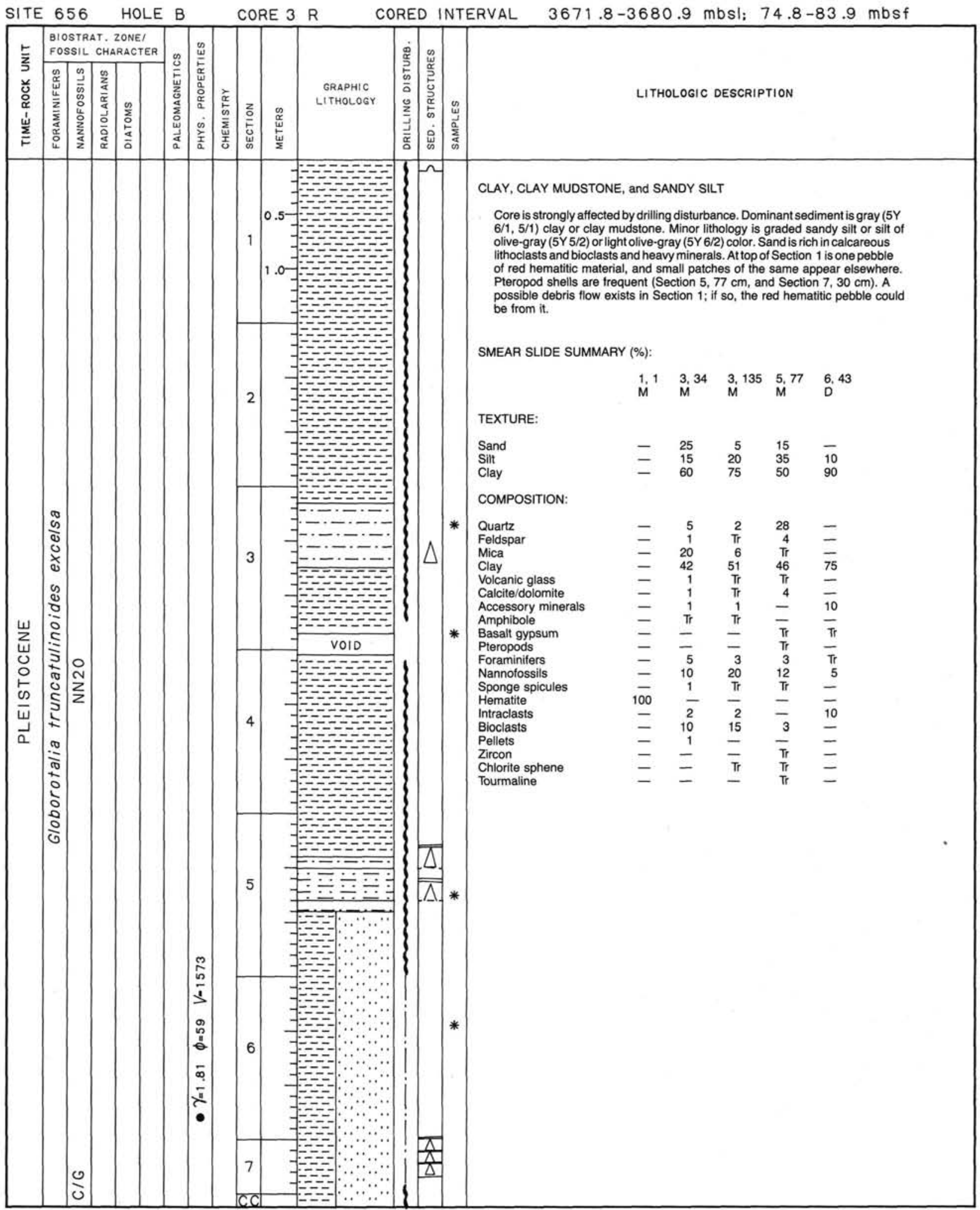




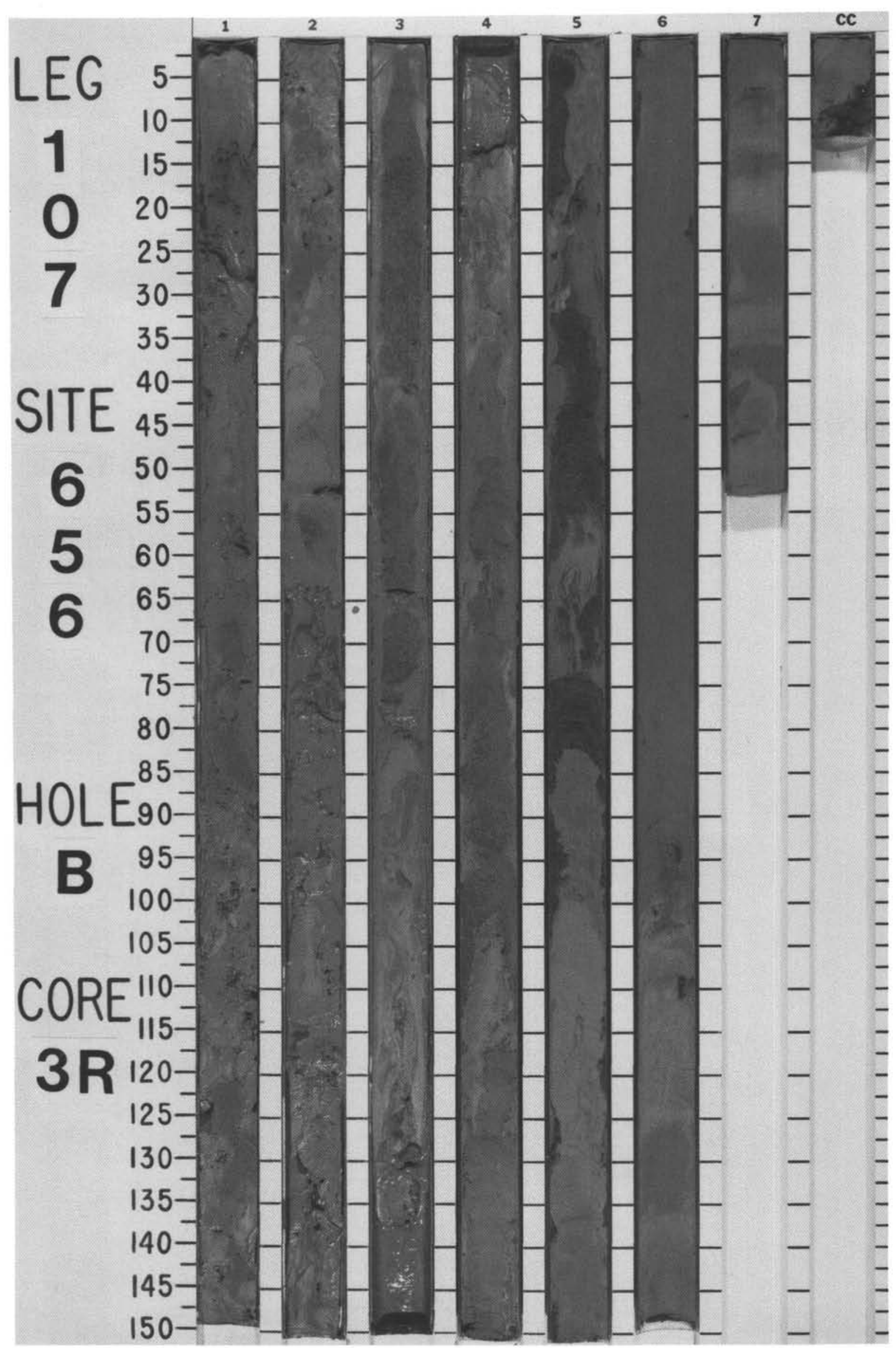




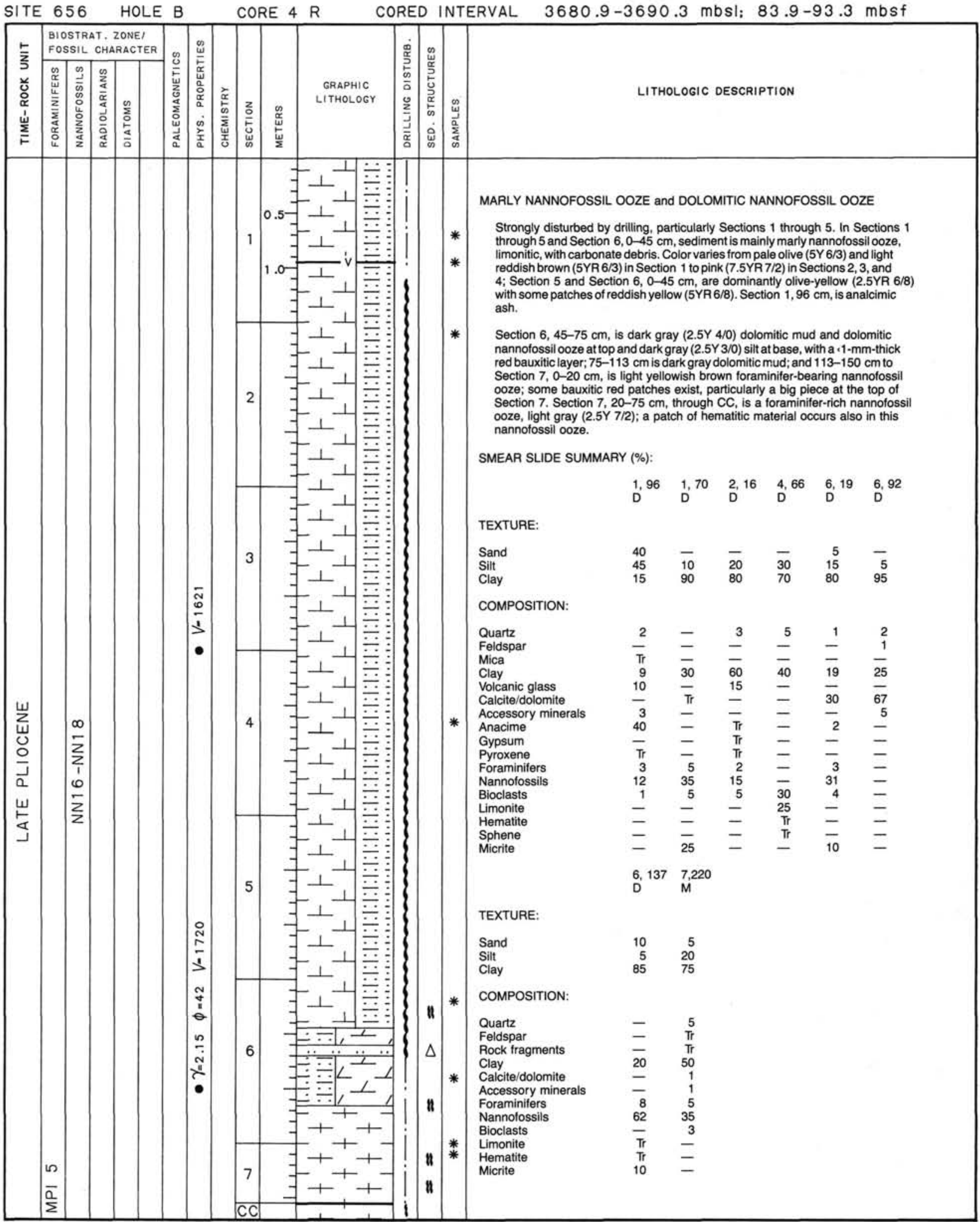




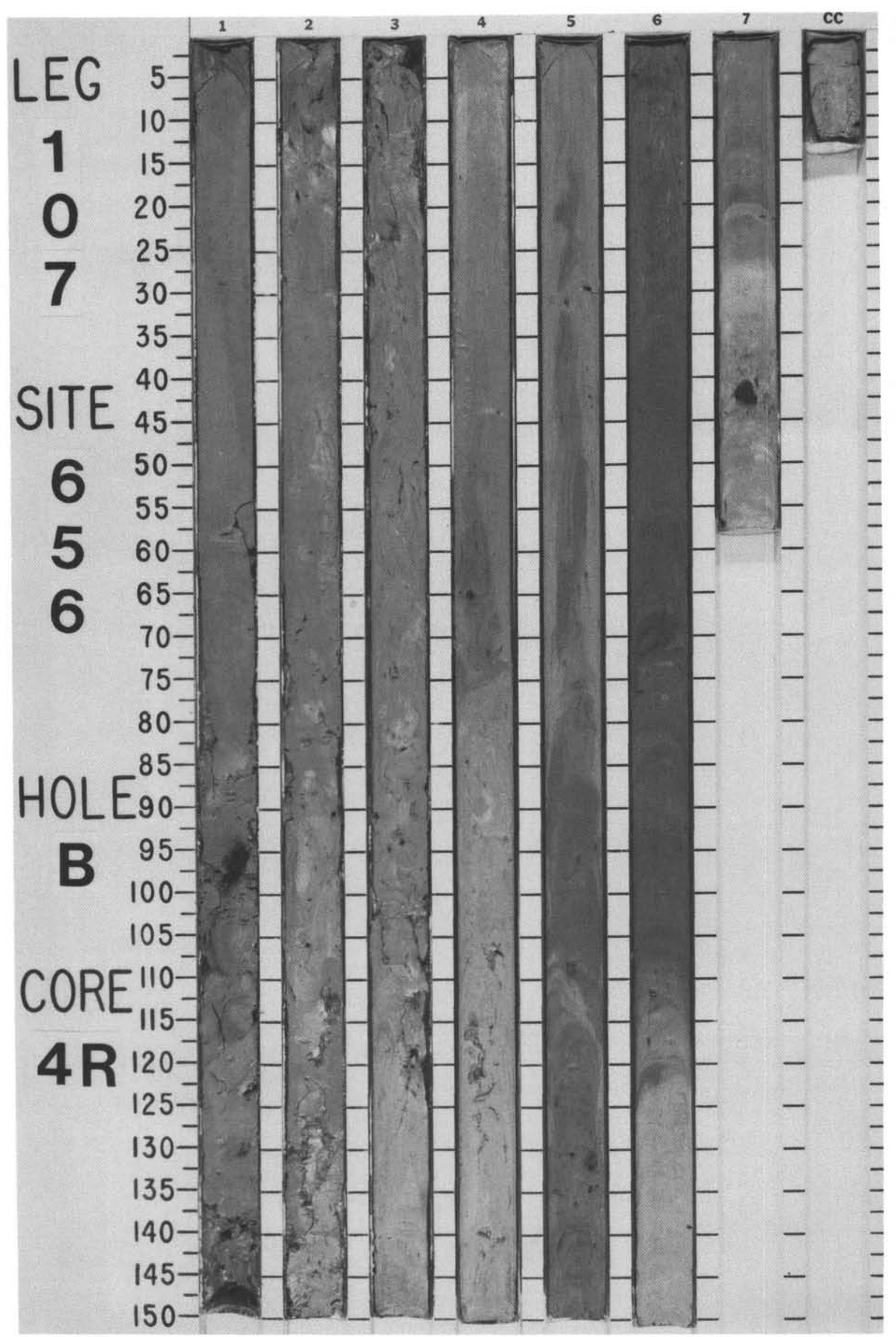


SITE 656 HOLE CORE 5 R

CORED INTERVAL

$3690.3-3699.9 \mathrm{mbsl} ; 93.3-102.9 \mathrm{mbsf}$

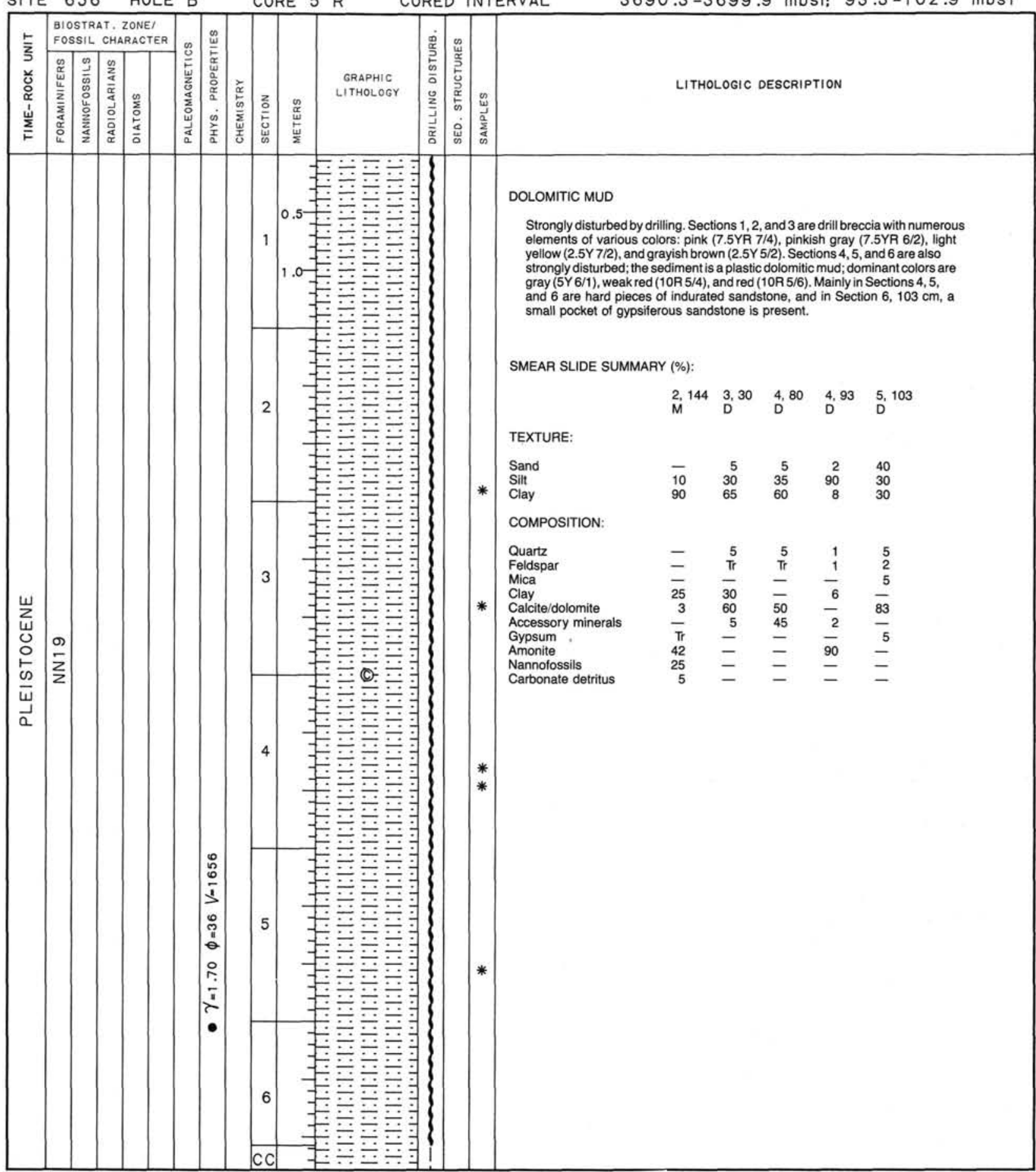




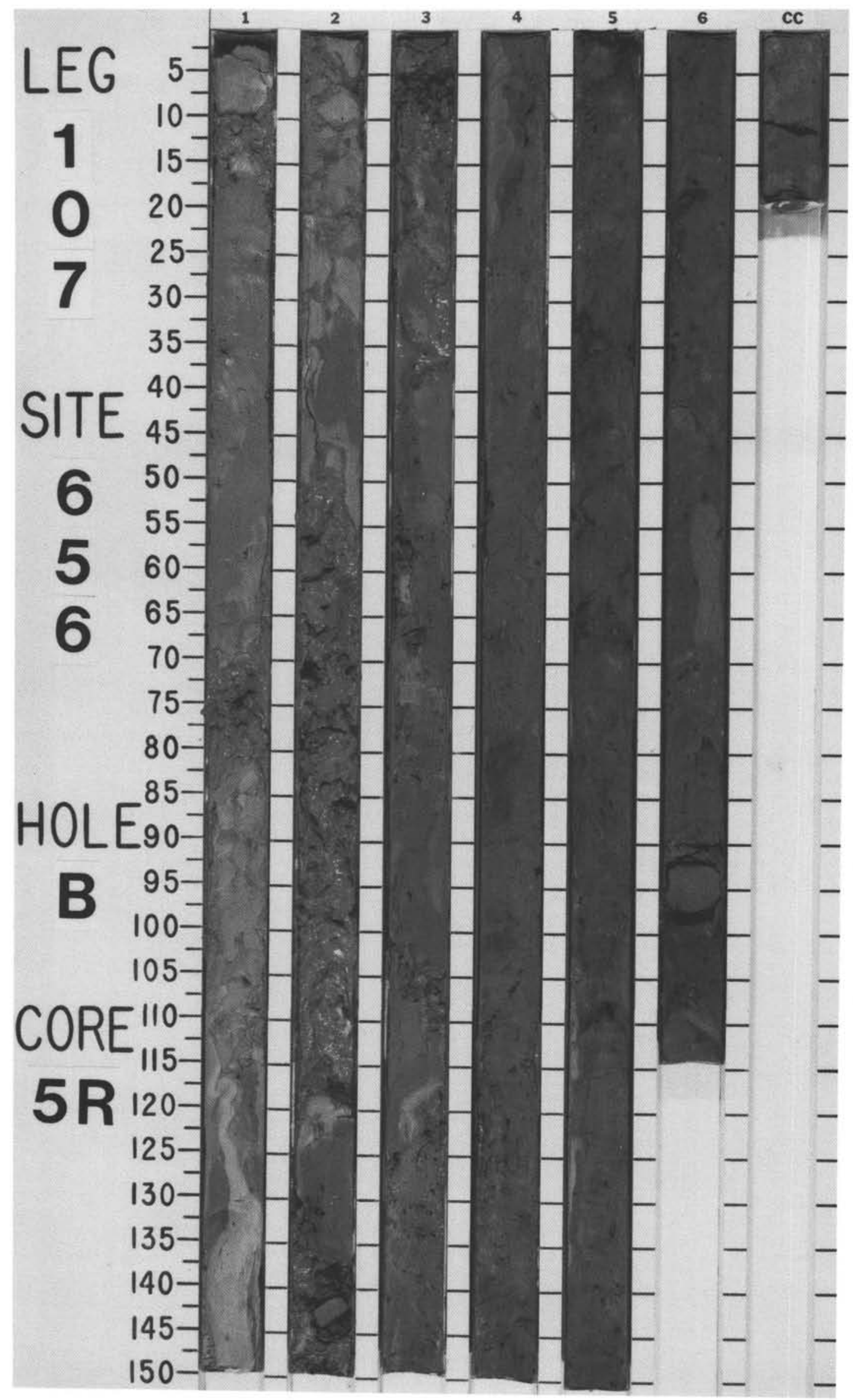




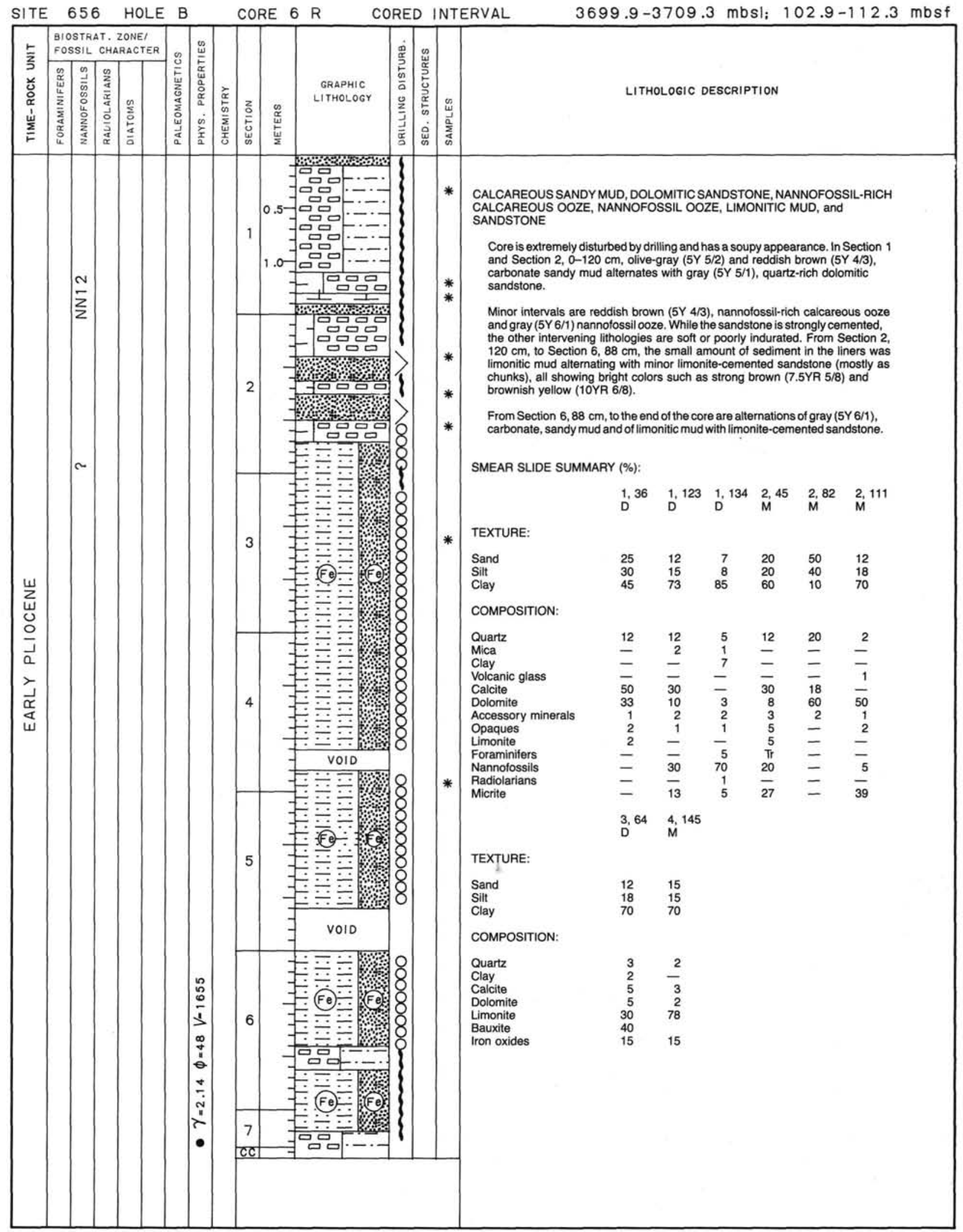




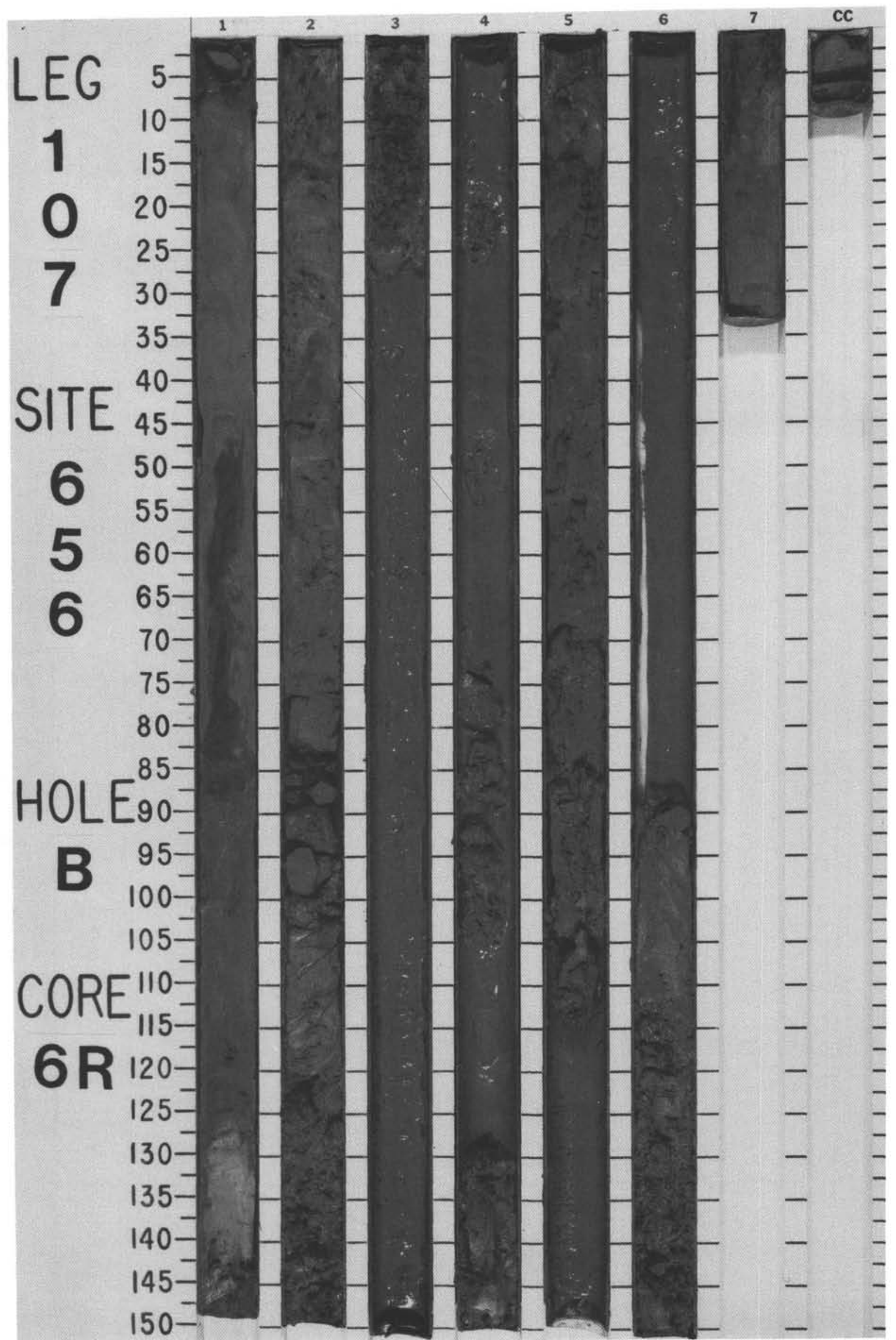




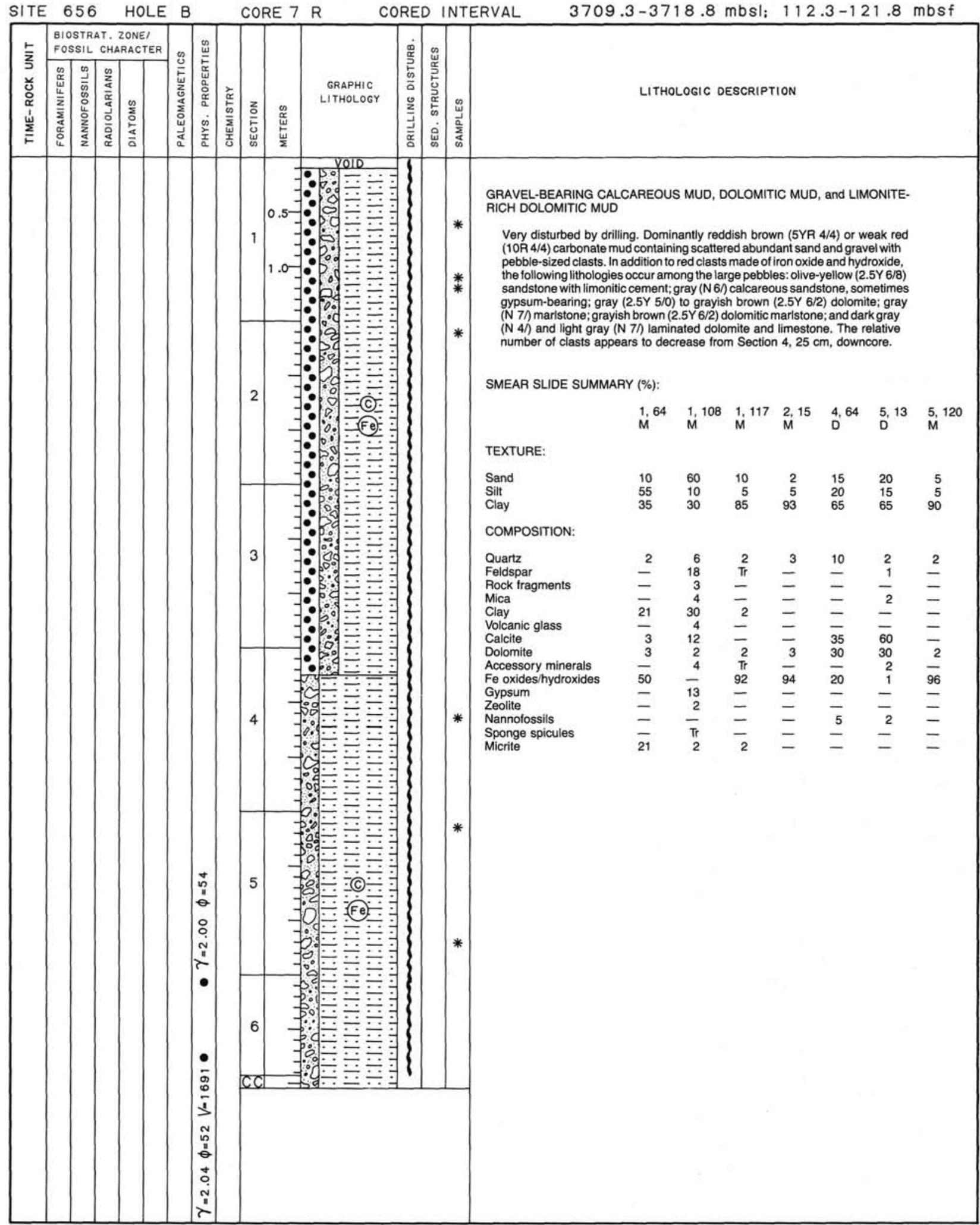




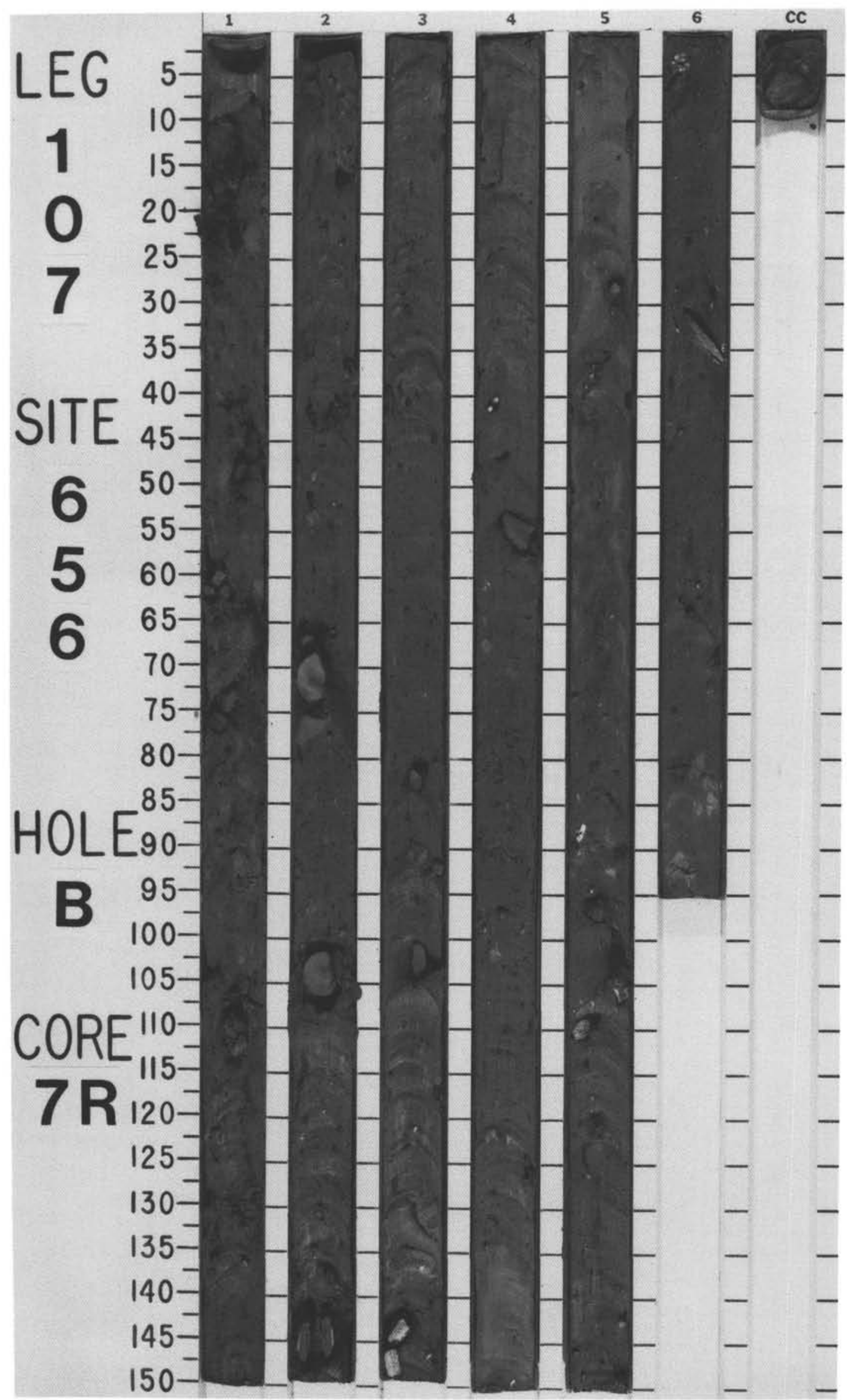

